\title{
The Use of Hot-Dry-Rock Geothermal Resources for Space Heating: A Case Study
}

R. G. Cummings*

C. J. Arundale**

R. L. Bivins

H. S. Burness*

R. H. Drake

R. D. Norton*

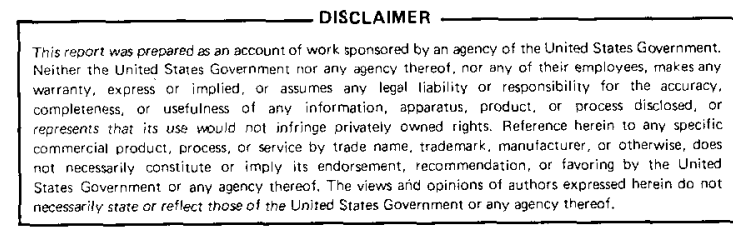

*Visiting Staff Member at: Los Alamos. Economics Department; University. of New Mexico; Albuquerque, NM 87131.

**Graduate Research. Assistant at Los Alamos. Economics Department, University of New Mexico, Albuquerque, NM 87131. 


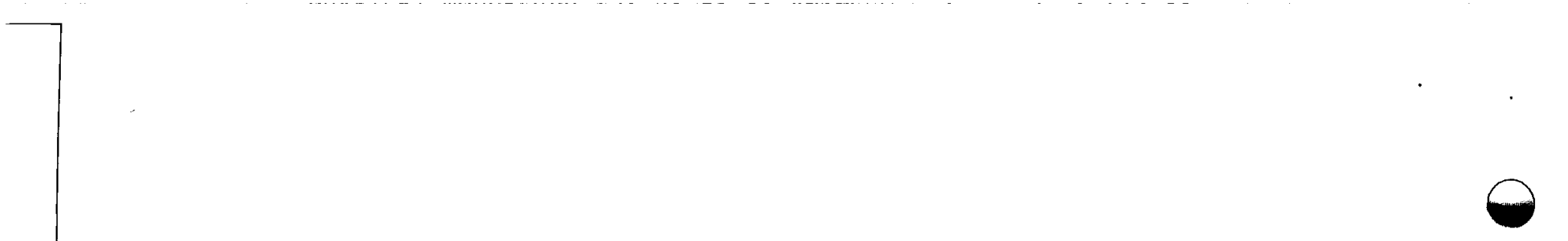

$\vartheta$

$\theta$

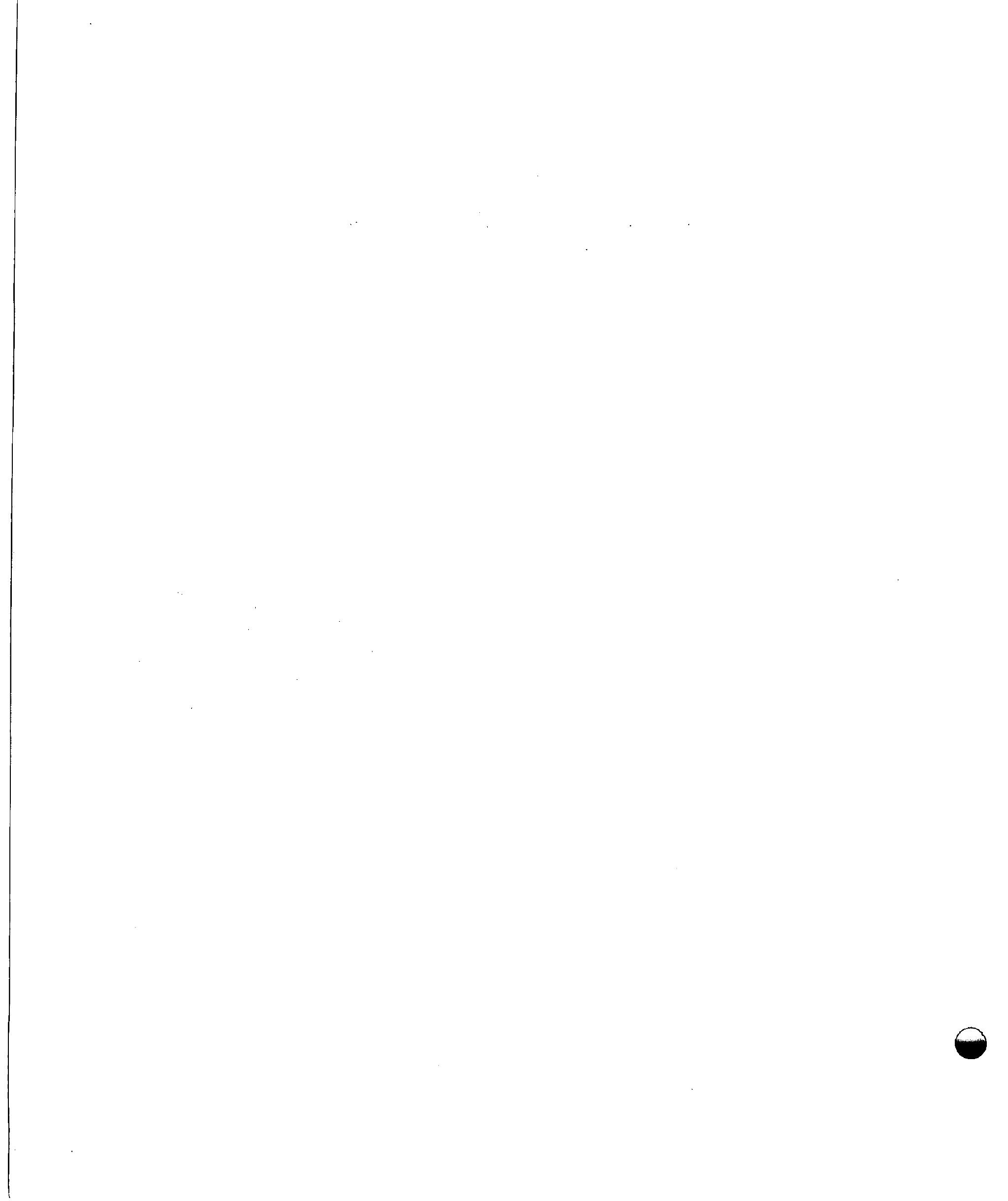




\section{DISCLAIMER}

This report was prepared as an account of work sponsored by an agency of the United States Government. Neither the United States Government nor any agency Thereof, nor any of their employees, makes any warranty, express or implied, or assumes any legal liability or responsibility for the accuracy, completeness, or usefulness of any information, apparatus, product, or process disclosed, or represents that its use would not infringe privately owned rights. Reference herein to any specific commercial product, process, or service by trade name, trademark, manufacturer, or otherwise does not necessarily constitute or imply its endorsement, recommendation, or favoring by the United States Government or any agency thereof. The views and opinions of authors expressed herein do not necessarily state or reflect those of the United States Government or any agency thereof. 


\section{DISCLAIMER}

Portions of this document may be illegible in electronic image products. Images are produced from the best available original document. 


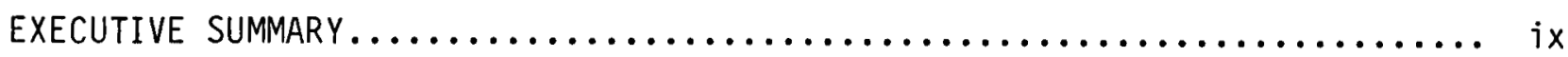
ABSTRACT.

I. INTRODUCTION.

II. BENEFITS TO THE WFC FROM AN HDR SPACE HEAT APPLICATION........... 3

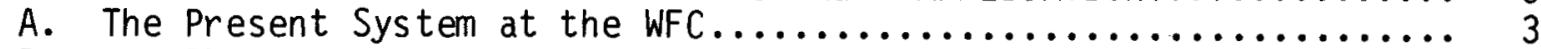

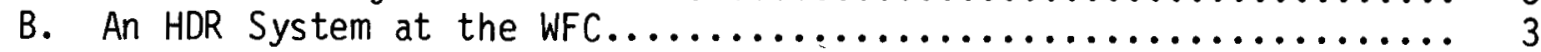

C. Gross and Net Benefits to WFC from the HDR System............ 5

III. IMPORTANT ECONOMIC CONSIDERATIONS RELEVANT TO THE HDR SYSTEM....... 7

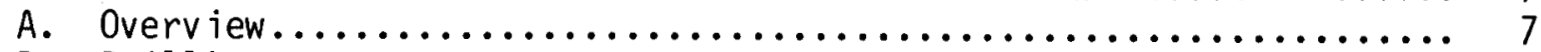

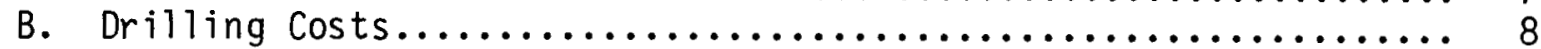

1. HDR Program, the Lab............................ 8

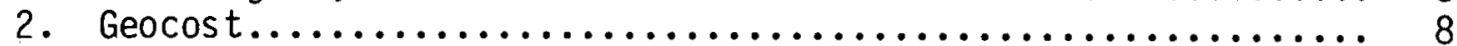

3. Republic Geothermal, Inc. (RGI) ................... 8

4. Other Geothermal Projects (OGP).................... 8

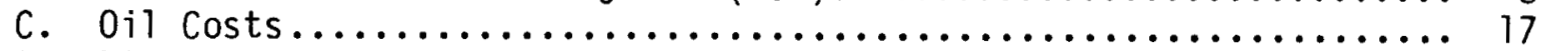

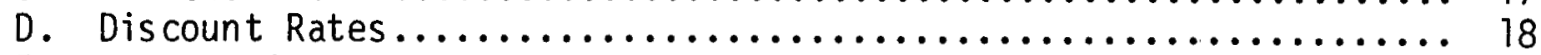

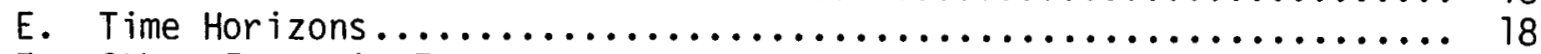

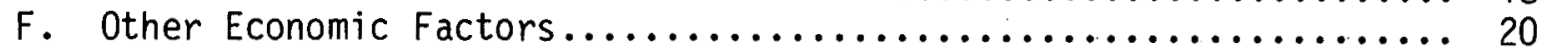

IV. IMPORTANT TECHNICAL CONSIDERATIONS RELEVANT TO THE HDR

SYSTEM AND BASE CASE ASSUMPTIONS....................... 21

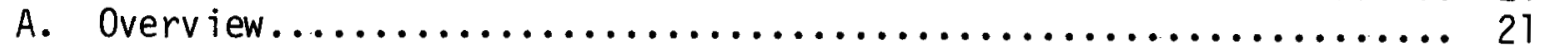

B. Reservoir Design, Well Flow Rates, and Temperature

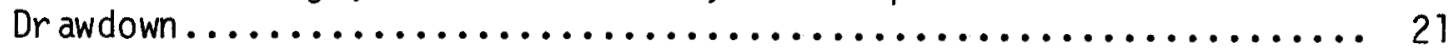

C. Depth to Basement and Geothermal Temperature Gradients........ 25

D. Base Case Assumptions and Sensitivity Analyses............... 26

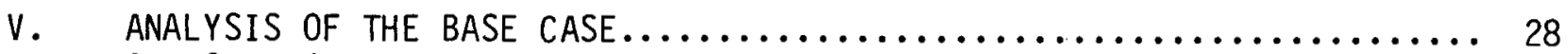

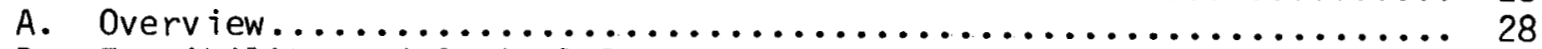

B. Feasibility and Optimal Design for the HDR System............. 28

C. Minimum Reservoir Design.......................... 33

D. Minimum Reservoir Design: Without the Preheat Option.......... 37

E. Summary..................................... 37

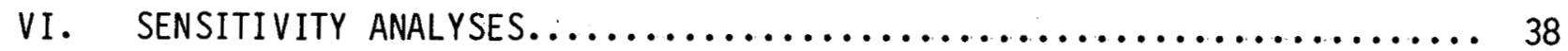

A. Sensitivity Analyses for Economic Parameters ............... 38

B. Sensitivity Analyses for Design Parameters................. 42

VII. CONCLUSIONS ................................. 47

A. Space Heat From HDR Resources at the Wallops Fiight

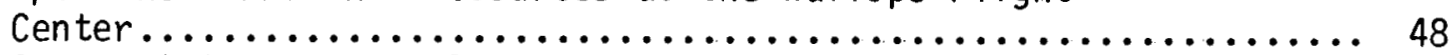

B. Generalizing the Results.......................... 49 
APPENDIX A: Estimates for Geocost Drilling Costs...................

APPENDIX B: RGI Drilling Costs............................ 55

APPENDIX C: Factors Affecting Drilling and $0 i 1$ Costs.................. 61

APPENDIX D: Estimates for Temperature Drawdown.................... 74

REFERENCES........................................... 77

F IGURES

1. Schematic of re-drilling option............................ 6

2. Typical drilling costs for geothermal wells.................... 10

3. Schematic of multiple-fracture concept.................... 24

B-1. Schematic of HDR reservoir geometry base case................ 60

C-1. A shift in the supply function in the face of both inelastic and elastic demand......................................... 70 
I. Fixed System Characteristics.............................

II. Summary of Results for WFC .............................. xii

I. Gross Benefits to the HDR System........................ 7

II. Alternative Drilling Cost Estimates...................... 9

III. Average Annual Compound Growth Rates for Drilling Costs.......... 13

IV. Average Drilling Costs and Standard Deviations................ 13

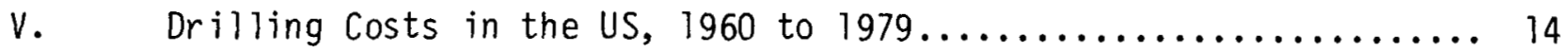

VI. GNP Price Deflator for the US, 1960 to $1979 \ldots \ldots \ldots \ldots \ldots \ldots \ldots . . . \ldots$

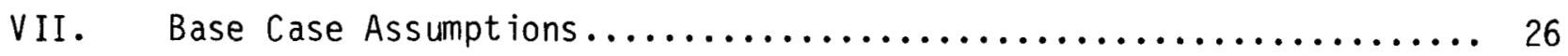

VIII. Values Used for Sensitivity Analyses..................... 27

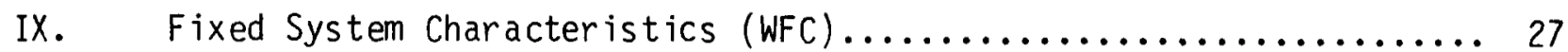

X. Initial Drilling Depths and Number of Fractures............... 29

XI. Time Path of Reservoir Temperatures and Well Flow Rates for Base Case, Four Fractures................................ 31

XII. Present Value of HDR System Costs and Net Benefits for Alternative Reservoir Designs: Base Case.................. 32

XIII. Performance of the HDR System with 1 Fracture and Preheat Option: Base Case...................................... 35

XIV. Feasibility Measures for the HDR System With Alternative Discount Rates........................................

XV. System Costs and Net Benef its for the HDR System Using Preheat Option with Alternative Increases in Real 0 il Prices.............

XVI. System Costs and Net Benefits for the HDR System, Without Preheat Option, for Alternative Increases in Real Drilling Costs........ 42

XVII. Benefits and Costs to the HDR System with Alternative Combinations for Increases in Real 0il Prices and Real Drilling

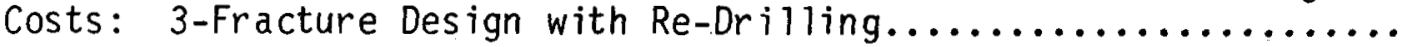

XVIII. Net Benefits to the HDR Space Heat Application with Alternative Relative (to oil) Increases in Drilling Costs......... 
XIX. Benefits and Costs for HDR System with Alternative Contingency Factors: Reservoir Design with 4 Fractures................. 44

$X X$. Benefits and Costs for HDR System with Alternative Btu Requirements.................................. 45

XXI. Benefits and Costs for HDR System with Temperature Drawdown

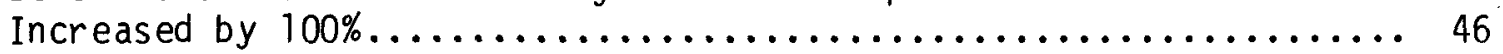

XXII. Benefits and Costs for HDR System with Alternative Site Characteristics: Depth to Basement and Geothermal Gradient....... 47

XXIII. Summary of Results: The WFC Case Study.................. 50

XXIV. Summary of Results Related to General Space Heat Applications

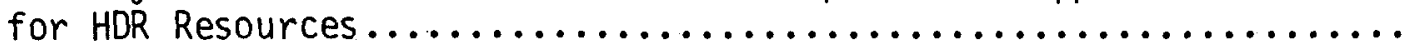

A-I. Estimated Drilling Costs from Updated Geocost Program:

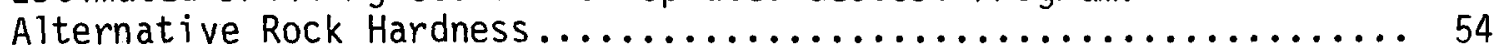

B-I. Sample of Key Parameters in the RGI Drilling Cost Program....... 57

B-II. Components of RGI Drilling Cost Estimates............... 58

B-III. Example of RGI Casing and Drilling Programs: Base Case......... 59

C-I. Costs of Drilling Deep Wells for $0 i 7$ and Gas............... 61

C-II. Annual Rates of Change of Drilling Costs, US Average Cost per

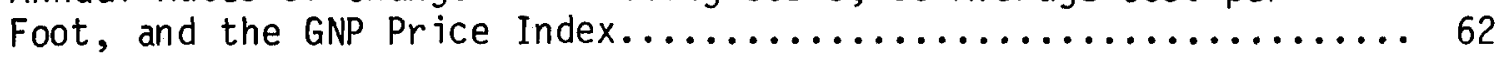

C-III. Well Drilling Costs in the US: 1960 to $1979 \ldots \ldots \ldots \ldots \ldots \ldots . \ldots 6$

C-IV. Alternate Projections of the Real Rate of Increase of Drilling Costs.......................................... 68

C-V. Alternate Projections of the Real Rate of Increase of Drilling

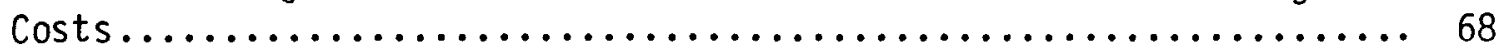

C-VI. Petroleum Prices, 1960 to 1977: Realized Prices of Saudi

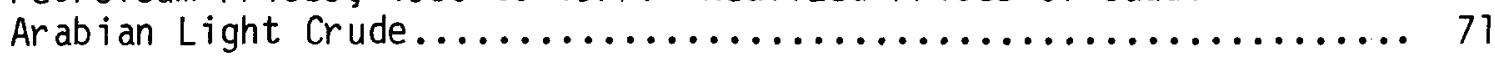

C-VII. Average OPEC Official Sales Price for Crude $0 i 1 \ldots \ldots \ldots \ldots \ldots . \ldots 72$

C-VIII. OECD Energy Supply Assumptions Underlying the Wharton 011 Price

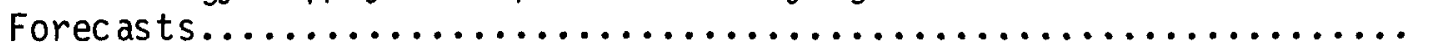




\section{EXECUTIVE SUMMARY}

This study represents an extension of economic studies conducted by the Los Alamos National Laboratory (the Lab) concerning the potential commercial feasibility of extracting energy from hot dry rock (HDR) geothermal resources. Earlier studies focused primarily on the use of HDR resources as a source of energy for the generation of electricity. This study considers the potential feasibility of using HDR resources for providing space heat.

The feasibility of using HDR resources for space heating is examined within the context of a case study using HDR resources to provide space heat requirements for the National Aeronautics and Space Administration's Wallops Flight Center (WFC) at Wallops Island, Virginia. WFC was chosen primarily because the center is considering changes in its main plant space heating system, which is now a steam system. A NASA-sponsored study concerning the feasibility of using "wet" (liquid dominated) geothermal resources at the WFC was only recently completed. Thus, using the WFC as a case study appeals on at least two grounds: geothermal energy for space heat at the WFC is a real possibility, and considerable data are readily available.

The purpose of the study is twofold: first, to examine conditions under which the use of HDR geothermal resources might be economically feasible as an energy source for the WFC and second, to examine the sensitivity of feasibility measures for space heat uses of HDR resources to a number of important economic and technical parameters while addressing questions related to optimal designs for HDR reservoirs. Economic parameters considered include drilling costs, oil prices, and discount rates; technical parameters considered include reservoir temperature drawdown rates, drilling technologies, and geothermal temperature gradients. In terms of reservoir design, primary attention is given to the optimum, but cost effective, number of fractures in the HDR reservoir system.

Characteristics of the WFC space heating system are given in Table I. To provide the center's annual energy requirements for space heating of $72.8 \times 10^{9}$ Btus, a set of economic and technical assumptions is used to develop a structure for the HDR system. The base case assumptions (BCA) follow. 
Base Case Assumptions

Economic Assumptions

- 1980 fuel costs for conventional steam system: $\$ 879152$ (26 667 bbl of No. 6 oil at $\$ 33.00 / \mathrm{bbl})$.

- 30-year planning horizon: $71 / 4 \%$ real discount rate.

- Annual rate of increase in real oil prices: $3 \%$, drilling costs, $4.34 \%$.

- Republic Geothermal, Inc. (RGI) drilling costs (see App. B) with contingency factors: $50 \%$ (permeable material) and $15 \%$ (basement rock).

- Plugging costs: $\$ 358$ 160/operation.

- Pipe and heat exchanger costs: \$2.25 million.

Technical Assumptions

- Depth to basement: $9000 \mathrm{ft}$.

- Geothermal gradient: $30^{\circ} \mathrm{C} / \mathrm{km}$.

- Temperature drawdown (see App. D).

- Well flow rate: varied as required.

- Fracture diameter: $360 \mathrm{~m}$. spacing, $164 \mathrm{ft}$.

- Number of fractures: determined as the optimal number of fractures given all other BCAs.

- Btu requirement for WFC: $72.818 \times 10^{9}$.

TABLE I

FIXED SYSTEM CHARACTERISTICS

Energy Consumption

\begin{tabular}{|c|c|c|c|c|c|}
\hline \multirow[b]{2}{*}{$\begin{array}{c}\text { WFC } \\
\text { System Options }\end{array}$} & \multirow[b]{2}{*}{$\begin{array}{l}\text { Heating and } \\
\text { Constant Use } \\
\left(10^{9} \text { Btu) }\right. \\
\end{array}$} & \multicolumn{3}{|c|}{$\begin{array}{c}\text { Losses } \\
\left(10^{9} \text { Btu }\right) \\
\end{array}$} & \multirow[b]{2}{*}{$\begin{array}{c}\text { Flow } \\
\text { Requirements } \\
\left(\mathrm{kg} / \mathrm{sec} \text { at } 74^{\circ} \mathrm{C}\right) \\
\end{array}$} \\
\hline & & Boiler & $\begin{array}{r}\text { Feed } \\
\text { Water } \\
\end{array}$ & $\begin{array}{c}\text { Distribution } \\
\text { Line } \\
\end{array}$ & \\
\hline $\begin{array}{l}\text { Conventional } \\
\text { steam heating }\end{array}$ & 69.34 & 32.26 & 11.29 & 48.39 & 52.36 \\
\hline $\begin{array}{l}\text { Hot water } \\
\text { heating }\end{array}$ & 69.34 & 14.56 & 5.10 & 3.47 & 52.36 \\
\hline
\end{tabular}


Parameters subjected to sensitivity analyses are listed below. Given a characterization for the HDR system, analyses of drilling costs are conducted for alternative drilling depths. For each initial reservoir temperature, temperature drawdown (cooling of the HDR reservoir) is traced through time over 30 years. At any year in which reservoir temperature falls below the WFC's design temperature of $74^{\circ} \mathrm{C}$, re-drilling or preheat activities* are introduced. System costs are compared with the 30-year cost of oil for the WFC's conventional steam system (benefits attributable to the HDR system) for analyses of feasibility.

Values Used for Sensitivity Analyses

Economic Parameters

- Real discount rate: $4 \%, 10 \%$.

- Annual increase in real oil prices: $2 \%, 4 \%$; in drilling costs: $3 \%, 6 \%$.

- RGI drilling costs with contingency factors: permeable material: 100\%; basement rock: $50 \%, 100 \%$.

Technical Parameters

- Depth to basement $(\mathrm{ft}) /$ geothermal gradient $\left({ }^{\circ} \mathrm{C} / \mathrm{km}\right)$ combinations: $2400 /(25,30,35,40) ; 5700 /(25,30,35,40) ; 9000 /(25,35,40)$.

- Temperature drawdown: double rate determined in App. D.

- Btu requirement: $109.227 \times 10^{9}$ (50\% higher than base case); $36.409 \times 10^{9}(50 \%$ lower than base case).

It is useful to review some of the more critical basic assumptions that underlie the analyses. Initial drilling costs are based on estimates from the RGI study of drilling costs. For drilling depths in the $10000 \mathrm{ft}$ range, costs range from $\$ 8 . m i l l i o n$ to $\$ 12 . \mathrm{million}$ (for 1 fracture, $9.000 \mathrm{ft}$ depth to basement) as contingency factors range from $15 \%$ to $100 \%$. RGI drilling costs are $\$ 10.9$ million with a $50 \%$ contingency factor, compared with actual drilling costs for that depth incurred in the Lab's HDR drilling program of about $\$ 10$ million. Further, BCAs concerning future annual rates of increase in real $0 i l$ costs and drilling costs--3\% and 4.34\%, respectively--must be viewed as

${ }^{*}$ Re-drilling involves drilling a new injection well and the creation of a new reservoir for the HOR system. 
most conservative in terms of their effects on net benefits attributable the HDR system. Still another source for understating net benefits in the base case is the use of a $7.25 \%$ discount rate.* These considerations suggest that, notwithstanding uncertainties surrounding contingencies for drilling costs, the treatment of drilling costs in this work is sufficiently conservative to justify their use as credible estimates for assessing the space heat application of interest.

In addition, reservoir design and reservoir performance are particularly important considerations in assessments of net benefits attributable to the HDR system. Efforts are made in this work to use parameters that may understate the potential of this system. Thus, small fractures (164-ft diameter) are assumed; minimum reservoir design configurations (2 to 3 fractures) are considered in the analyses; and system management is limited to the control of well flow rates.

The following major conclusions are suggested by the results of this study (see Table II).

1. Energy for the WFC's space heat requirements can be provided by HDR geothermal resources at a lower cost than with the WFC's conventional, steam system; that is, the HOR System is economically feasible as an energy source for this space heat application.

2. The economic feasibility of the HDR space heat application holds under the following conditions:

--1 fracture, with the preheat option, $B C A$;

--3 fractures, without the preheat option, BCA;

--contingency factors for drilling time close to $100 \%, \mathrm{BCA}$;

--system scales (Btu requirements) between some 40-plus $\times 10^{9}$ Btu and 109-plus $\times 10^{9}$ Btu;

--a rate of temperature drawdown that is twice as rapid as the base case rate (for reservoir designs involving 4 or more fractures); and

--geothermal temperature gradients $25^{\circ} \mathrm{C} / \mathrm{km}$ and higher with depth to basement up to 9000 feet, BSA.

3. The use of HDR geothermal resources for preheated water at WFC is economically feasible under a wide $r$ ange of conditions.

*As future benefits and costs are both discounted, our analyses demonstra the preponderance of future benefit flows relative to future costs; thus, discounting effects are much more important for system benefits.

$x i i$ 
TABLE J]

SUMMARY OF RESULTS FOR WFC

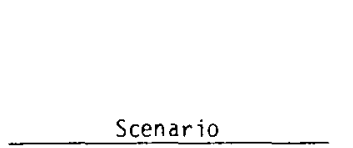

Base case

Base case, minimum

reservoir design:

with preheat

without preheat

Increase in real

drilling costs

(relative to oi

prices)

$$
\begin{aligned}
& 0.75 \\
& 3.00
\end{aligned}
$$

Contingency factors

for drilling

permeable/impermeable

material

$$
50 \% / 50 \%
$$

$100 \% / 100 \%$

System scale

( $10^{9}$ Btu)

36.4

109.2

Double temperature

drawdown--with

minimum reservoir

\begin{tabular}{|c|c|c|}
\hline \multicolumn{3}{|c|}{$\begin{array}{c}\text { Financial Summary } \\
\left(10^{6} \text {.dollars }\right)\end{array}$} \\
\hline $\begin{array}{l}\text { Gross } \\
\text { Benefits }\end{array}$ & $\cos t s$ & $\begin{array}{c}\text { Net } \\
\text { Benefits }\end{array}$ \\
\hline
\end{tabular}

design

15.0

10.9

4.1

0.1
2.9

15.0
15.0

14.9

4.0

17.0
13.3

13.0

$-1.2$

Reservoir

(No. of

Fractures)

4

Depth

Depth
$(\mathrm{ft})$

11699

Re-Drilling Preheat

$--$

30

14.5

$15.0 \quad 13$.

$\begin{array}{ll}15.0 & 13.2 \\ 15.0 & 15.7\end{array}$

1.8
-0.7

4

11699

11699

$\begin{array}{ll}-- & 30 \\ - & 30\end{array}$

\section{$7.5 \quad 14.3$}

$\begin{array}{rr}7.5 & 14.3 \\ 22.5 & 11 .\end{array}$

15.0

11.6

$-2.8$

$$
\begin{aligned}
& 2 \\
& 6
\end{aligned}
$$

11415

II 983

$-$

$12 \quad 125$

15.0

13.7

\begin{abstract}
3.4
\end{abstract}
1.3

13557

4 $\ddot{17}$

Site Characteristics

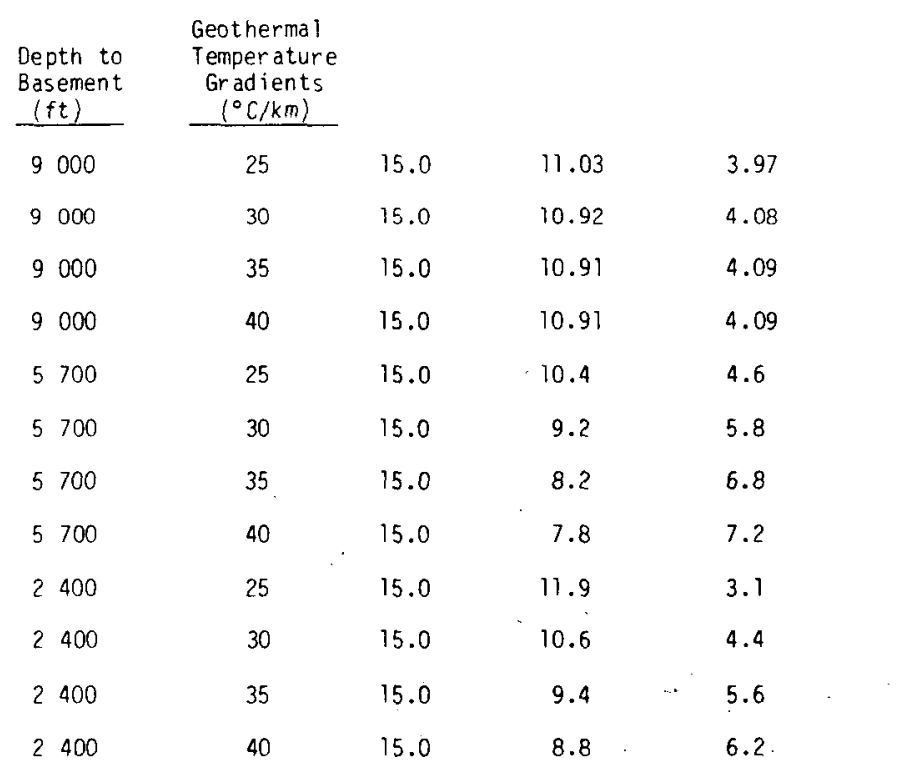


Generalizing the Results

A number of conditions peculiar to the WFC case study worked against the potential feasibility of providing space heat by HDR geothermal resources. Depth to basement rock ( $9000 \mathrm{ft}$ ) at the WFC site differs significantly from depths commonly encountered $(2000$ to $6000 \mathrm{ft}$ ). The geothernal gradient at the WFC site- $-30^{\circ} \mathrm{C} / \mathrm{km}--$ is low relative to gradients found in many locations $-40^{\circ} \mathrm{C} / \mathrm{km}$ and higher (the gradient at the Lab's Fenton Hill site is $\left.60^{\circ} \mathrm{C} / \mathrm{km}\right)$. Further, heating loads larger than the WFC's $72.8\left(10^{9}\right) \mathrm{Btu} / \mathrm{yr}$ may be found in more centralized locations, and the dispersion of the WFC's buildings requires much higher costs for distribution pipes than would be the case with more concentrated heat loads. One question remains. What about the economic feasibility of using HDR resources for space heat applications under more favorable conditions?

Relevant data for responding to this question are found in Table II. Consider, first, the case where heating loads are increased by $50 \%$, to 109.2 $\left(10^{9}\right) \mathrm{Btu} / \mathrm{yr}$, over the WFC's annual requirement of $72.8\left(10^{9}\right) \mathrm{Btu} / \mathrm{yr}$. Gross benefits are nearly double system costs, and net benefits of $\$ 11.1$ million are attributable to the HDR resource system. This level of space heat requirements is satisfied at only half the cost of the conventional oil system. Given the net benefits to the HDR system with this larger heat load, the HDR system would be feasible regardless of changes in drilling costs, contingencies in drilling, and/or rates of temperature drawdown.

With depth to basement in the 2400 - to 5 700-ft range and a geothermal temperature gradient of only 35 to $40^{\circ} \mathrm{C} / \mathrm{km}$, gross benefits are almost double system costs. As above, HDR costs are only half the costs of conventional systems, and net benefits of $\$ 6$ to $\$ 7$ million apply. Here again, net benefits are sufficiently large to absorb costs associated with uncertainties concerning drilling contingencies and rates of temperature drawdown.

Thus, we show that the HDR resource can be economically feasible in providing space heat requirements for the WFC under a wide range of economic and technical conditions. Clearly, the HDR resource is feasible under more general conditions with lower depth to basement and somewhat higher geothermal temperature gradients. These observations serve to identify the large social benefits that would attend access to this virtually omnipresent energy resource as a source for space and process heat. 
THE USE OF HOT DRY ROCK GEOTHERMAL RESOURCES

FOR SPACE HEATING: A CASE STUDY

by

R. G. Cummings, C. J. Arundale,

R. L. Bivins, H. S. Burness,

R. H. Drake, and R. D. Norton

\begin{abstract}
This study shows that a hot dry rock (HDR) geothermal space heat system proposed for the National Aeronautics and Space Administration's Wallops Flight Center (WFC) will cost $\$ 10.9$ million, saving $\$ 4.1$ million over the existing $0 i 1$ heating system over a 30-yr lifetime. The minimal, economically feasible plan for HDR at WFC is shown to be the design of a single-fracture reservoir using a combined HDR preheat and a final oil burner after the first 4 years of operation. The WFC cost savings generalize and range from $\$ 3.1$ million to $\$ 7.2$ million for other HDR sites having geothermal temperature gradients ranging from $25^{\circ} \mathrm{C} / \mathrm{km}$ to $40^{\circ} \mathrm{C} / \mathrm{km}$ and depths to basement rock of $2400 \mathrm{ft}$ or $5700 \mathrm{ft}$ compared to the $30^{\circ} \mathrm{C} / \mathrm{km}$ and $9000 \mathrm{ft}$ to basement rock at WFC.
\end{abstract}

\title{
I. INTRODUCTION
}

This study represents an extension of economic studies conducted by the Los Alamos National Laboratory (the Lab) concerning the potential commercial feasibility of extracting energy from hot dry rock (HDR) geothermal resources. Earlier studies focused primarily on the use of HDR resources as a source of energy for the generation of electricity. ${ }^{1-2}$ This study considers the potential feasibility of using HDR resources for space heating examined in this work within the context of a case study.

The case study involves the use of HDR resources for providing space heat requirements for the National Aeronautics and Space Administration (NASA) installation, Wallops Flight Center (WFC) located at Wallops Island, 
Virginia. Choice of the WFC for a case study was based primarily on the that the WFC is seriously considering changes in their main plant space heating system, which is now a steam system. Indeed, a NASA-sponsored study concerning the feasibility of using "wet" (liquid dominated) geothermal resources at the WFC was recently completed. ${ }^{3}$ Thus, use of the WFC as a case study has appeal on at least two grounds: the use of geothermal energy for space heat at the WFC is a real possibility, and considerable data are readily available.

The purpose of this study is twofold. First, as set out above, a major purpose of the study is to examine conditions under which the use of HDR geothermal resources might be economically feasible as an energy source for the WFC.* Second, an effort is made to examine the sensitivity of feasibility measures relevant for space heat uses of HDR resources to a number of important economic and technical parameters, and to address questions related to optimal designs for HDR reservoirs. Economic parameters considered include drilling costs, oil prices, and discount rates; technical parameters considered include reservoir temperature draw-down rates, drilling technologies, and geothermal temperature gradients. In terms of reservoir design, primary attention is given to the optimum--cost effective--number of artificial fractures required to form the HDR reervoir system.

The study is organized in the following fashion. A brief description of the WFC's space heating needs and distribution systems is given in Sec. II; included in this section is a discussion of the benefits that may accrue to the WFC as a result of using HDR resources as an energy source. In Secs. III and IV attention focuses on some of the major economic and technical parameters relevant for assessing the feasibility of space heat applications for HDR geothermal resources. These analyses result in the development of a base case characterization for the HDR system. The base case serves as a representation of the HDR system under what would appear to be reasonable expectations as to future economic and technical conditions relevant for assessing the system's feasibility. Further, base case analyses serve as a point of reference for sensitivity analyses. Base case results are analyzed in

\footnotetext{
*As discussed below, a major disadvantage of using the WFC was found to be the following. In the area of the WFC, the depth to basement (depth impermeable granite) is unusually large: some 9000 feet. This atypi characteristic limits the generality of case study results.
} 
c. $V$, and results from sensitivity analyses are described in Sec. VI. Conclusions from the study are presented in Sec. VII.

\section{BENEFITS TO THE WFC FROM AN HDR SPACE HEAT APPLICATION}

A. The Present System at the WFC

NASA's Wallops flight Center consists of a main base and a launch facility. The main base (of primary concern here) covers an area of 4921 acres on which are located 53 buildings with approximately $500000 \mathrm{sq} f t$ of floor space (Ref. 3, p. 3-1 and Table 3-1). Space heating for the main base is provided by a central steam plant, which produces 125 psig steam using, primarily, No. 6 oil. About two miles of steam distribution piping and two miles of condensate return piping are used (Ref. 3, p. 3-1). Over the period 1974 to 1978, annual fuel (No. 6 oil) consumption at the central steam plant was 1.12 million gallons (26 667 barrels) with a fuel heat value (at $144000 \mathrm{Btu} / \mathrm{gal}$.$) of 161.3$ billion Btu (Ref. 3, Table 4-1). Of the 161.3 billion Btus consumed at the WFC, $43 \%\left(69.34 \times 10^{9}\right.$ Btus $)$ results in heating and constant use (domestic hot water and reheat humidity control) energy supplies, $20 \%\left(32.26 \times 10^{9}\right.$ Btu $)$ goes for boiler losses, with $7 \%$ and $30 \%$ consumed by feed water losses and distribution system line losses, respectively. ${ }^{3}$

B. An HDR System at the WFC

According to the chief engineer at the WFC, ${ }^{*}$ the bulk of old distribution pipes in the main base system is being replaced, and the resulting distribution system, as well as heat transfer systems, may be used for the direct circulation of fluids used in the HDR system. With the new piping system, it is estimated that distribution system line losses that would attend the circulation of hot water $\left(74^{\circ} \mathrm{C}\right)$ from the HDR system would be $5 \%$.

If the local HDR resource is to be used as an energy source for space heating and constant use purposes, a pair of wells would be drilled on WFC grounds and a reservoir--essentially, one or more large cracks or fractures in impermeable granite*ᄎ_-would be established. Water would be injected into the

*Various telephone conversations with Mitch Brown, chief engineer, WFC, 1981. 6*The number of connected fractures in this system is discussed below. 
reservoir through the first, injection, well; pass across the surface area of the fracture(s) thereby increasing in temperature from its injection temperature to the average temperature of the fracture; and return to the surface by the second, or production, well. The heated water (subjected to conditions described below) is then circulated through the existing WFC distribution system for heating purposes. Important characteristics of the WFC area and heating system for the use of HOR resources, as sketched above, follow.

- Average geothermal temperature gradient:

$30^{\circ} \mathrm{C}$ per kilometer

of depth.*.

- Depth to basement rock

$9000 \mathrm{ft}$ (See Ref. 3, p. 5-3.)

- $\quad$ Surface system

temperature drop $(\Sigma T)$ :

$11.11^{\circ} \mathrm{C}\left(20^{\circ} \mathrm{F}\right)$ (See Ref. 3, p. $6-2.)^{9}$

- Average temperature

requirements at WFC:

$74^{\circ} \mathrm{C}$ (See Ref. 3, p. 6-1.)

- Fluid flow rate

for WFC system:

$52.36 \mathrm{~kg} / \mathrm{sec} * \star$

- Average annual Btu requirements, WFC main base:

$72.81 \times 10^{9} \mathrm{Btu}^{\dagger}$

In meeting the WFC requirements given above, the HDR system would operate in the following manner. A detailed description of this system is given in a companion report to this study. 4

(i) Water, at a flow rate of $\dot{m}_{w e} 1$, is injected into the HDR reservoir at a temperature $\mathrm{T}_{j}\left(74^{\circ} \mathrm{C}-11.11^{\circ} \mathrm{C}=62.89^{\circ} \mathrm{C}\right)$ and returns to surface at a temperature $T_{w e 11}$. If $T_{\text {well }}$ exceeds the WFC's temperature requirement $T_{d}\left(74^{\circ} \mathrm{C}\right)$, make-up water $\left(\dot{m}_{s}\right)$ is mixed with $\dot{m}_{\text {well }}$ such

*Data from F. Goff, staff member, Los Alamos National Laboratory, 1981; also see Ref. 3, p. 5-3.

**See equation, Table IX, for derivation of fluid flow rate.

With $5 \%$ distribution line losses, $69.34 \times 10^{9}$ Btu for heating constant use (Ref. 3, p. 4-2). 
that the design flow rate $\dot{m}_{d}(52.36 \mathrm{~kg} / \mathrm{sec})$ at $T_{d}=74^{\circ} \mathrm{C}$ is satisfied. As long as $T_{\text {we }} 1$ exceeds $74^{\circ} \mathrm{C}$, the well flow rate mell can be reduced below $52.36 \mathrm{~kg} / \mathrm{sec}$, thereby reducing the rate of temperature drawdown in the HDR reservoir.*

(ii) If reservoir temperature, $T_{\text {well }}$, is less than $74^{\circ} \mathrm{C}$, one of two options may be exercised. First, one can close (plug) the HDR system's production well, and drill a new production well as shown in Fig. 1. Associated with this re-drilling option is a cost $C_{R} \cdot \star \star$ Second, one can use the WFC's existing boiler system using water from the HDR reservoir as preheated water. Thus, if $T_{\text {well }}$ is $70^{\circ} \mathrm{C}$, No. 6 oil is burned to raise the flow of $52.36 \mathrm{~kg} / \mathrm{sec}$ of water at $70^{\circ} \mathrm{C}$ to $74^{\circ} \mathrm{C}$. With $27 \%$ boiler and feed water losses, 1382 barrels of No. 6 oil would be required in this preheat option for each $1{ }^{\circ} \mathrm{C}$ difference between $T_{\text {well }}$ and the design temperature of $74^{\circ} \mathrm{C} . \dagger$ The preheat option would then involve a cost $C_{P H}$. If $C_{P H}$ is less (greater) than $C_{R}$, the preheat (re-drilling) option is used when $T_{\text {well }}$ falls below $74^{\circ} \mathrm{C}$.

C. Gross and Net Benefits to WFC from the HDR System

Based on the above discussions, gross and net benefits to the WFC attributable to the use of HDR geothermal resources for space heating can now be defined. Gross benefits are reasonably straightforward. They are avoided costs--costs that the WFC would pay for No. 6 fuel oil if the present, conventional fuel system is used for space heating over the time horizon of concern here (30 years).

Three types of information are required for the calculation of gross benefits: annual $0 i 1$ costs associated with the use of the present, conventional system; the rate of increase in real oil costs over the 30-year planning period; and the real, inflation-free discount rate. The average annual use of No. 6 oil for space heating at the WFC was given above as 26667 bbl per year; the average price of No. 6 oil--less than $0.3 \%$ sulphur

*The cooling of rock temperatures in the HDR reservoir that attends $\dot{m}_{\text {well-- }}$ referred to as temperature drawdown--is discussed in Sec. III.

${ }^{\star *}$ Drilling costs are examined in Sec. III. Technologies other than that shown in Fig. 1 may be used for re-drilling, as will be discussed in Sec. III.

$T(52.36 \mathrm{~kg} / \mathrm{sec})(4200)(3600)(24)(365) \div 1.054=6.58 \times 10^{9} \mathrm{Btu}\left(6.58 \times 10^{9}\right)$ $(1.27) \div(144000)(42)-$-Btus per bbl of No. 6 oil--yields 1382 bbl. 


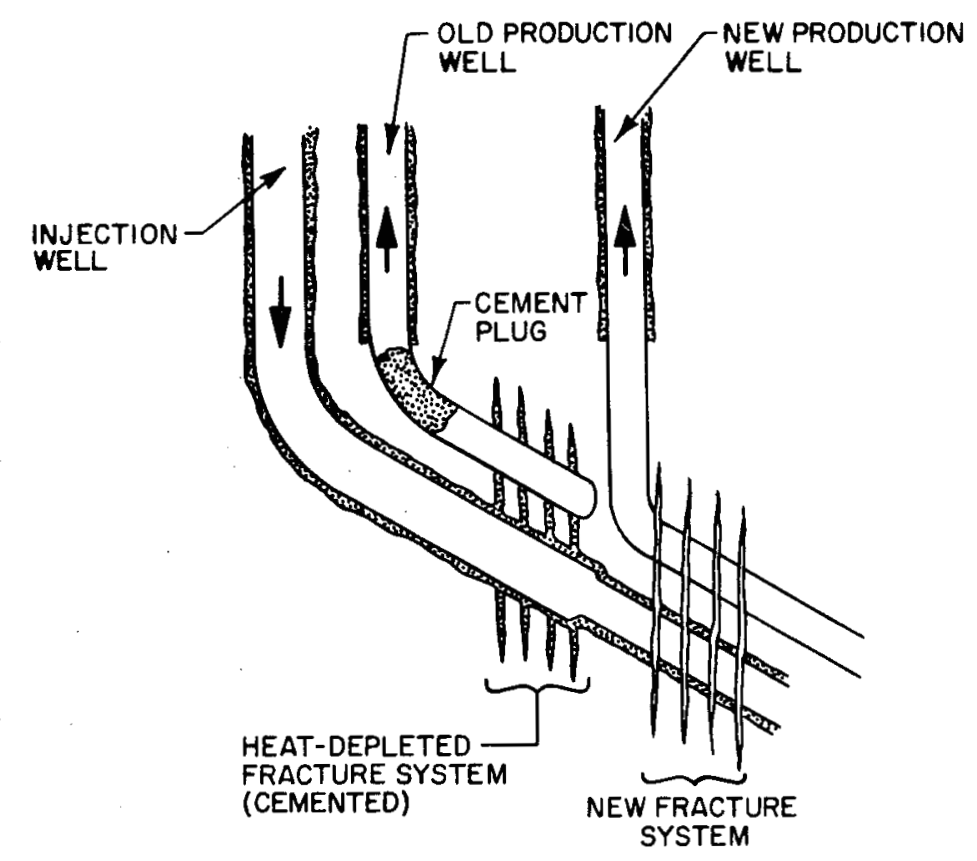

Fig. 1. Schematic of re-drilling option.

content*--was $\$ 31.13$ in 1980 ; $*$ with this price increased by $6 \%$ to reflect transportation, handling costs, and taxes, the average 1980 fuel cost for the conventional system is assumed to be $\$ 879152$.

For purposes of analysis, it is desirable to express the annual fuel cost of the conventional system, $\$ 879152$, as present values over the 30-year planning horizon. For reasons detailed in Sec. III, three real rates of discount are used for this purpose: $4 \%, 71 / 4 \%$, and $10 \%$. Further, because all values used in this report are given in 1980 dollars unless otherwise specified, an estimate is required for the manner in which real oil prices will change over the 30-year planning horizon. Again, three estimates for the annual rate of increase in real, inflation-free oil prices are used in this work (justification for which is discussed in Sec. III): $2 \%, 3 \%$ and $4 \%$. Thus, the present value, over a 30-year planning horizon, of the avoided costs from the conventional system for providing space heating at the WFC--gross benefits attributable to the HDR system--is given in Table I.

*The WFC uses the low sulphur oil, according to Mitch Brown, Chief Engineer at the WFC.

$\star \star$ Data from the DOE's Energy Information Agency, August 14, 1981. 
TABLE I

GROSS BENEF ITS TO THE HDR SYSTEM

(106 1980 dollars)

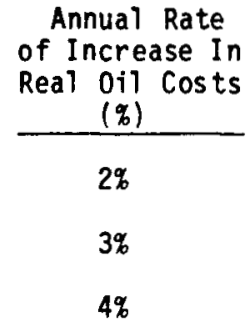

\begin{tabular}{lcc}
\multicolumn{3}{c}{$\begin{array}{c}\text { Real Discount Rate } \\
\text { (per cent) }\end{array}$} \\
\hline$\frac{71 / 4}{19.8}$ & $\frac{71 / 4}{13.3}$ & $\frac{10}{10.1}$ \\
22.8 & $15.0^{2}$ & 11.1 \\
26.4 & 17.0 & 12.4
\end{tabular}

aGross benefits for the base case.

Of course, net benefits to the HDR system will consist of gross benefits, as given above, less the following costs: costs associated with establishing the HDR system itself; re-drilling costs, and/or costs associated with the preheat option. Attention is now turned to an analysis of these costs as well as an analysis of other considerations that are of particular importance in assessing the feasibility of using HDR geothermal resources for space heating at the WFC.

III. IMPORTANT ECONOMIC CONSIDERATIONS RELEVANT TO THE HDR SYSTEM

A. Overview

The purpose of this and the following section is to develop a base case set of assumptions for use in assessing the potential feasibility of using HDR resources for space heat needs of the WFC, as well as to establish a rationale for sensitivity analyses relevant in this regard. To these ends, a number of technical and economic processes and parameters must be considered. Economic parameters must be considered within. the context of today's setting as well as likely settings in the future; the same applies to technical parameters. Economic factors considered and treated in this section include: drilling costs, oil costs, discount rates, and time horizons; other, more technical, factors considered in Sec. IV include: reservoir design: and temperature drawdown. Following these discussions, a rationale for base case and sensitivity analyses will be developed in Sec. IV. 
B.

Drilling Costs

There are two aspects of drilling costs that are particularly important for this study. What are the costs for drilling and establishing HDR wells and reservoirs? How are such costs likely to increase in the future?

Consider first how one best characterizes drilling costs. Four sources for drilling cost estimates are the following.

1. HDR Program, the Lab. Data are available for estimated drilling costs for five wells drilled at the Lab as a part of the HDR program: GT-1 (1973), GT-2 (1974), EE-1 (1975), EE-2 (1981) and EE-3 (1980). These costs are given in column 2 of Table II.

2. Geocost. Geocost is a drilling cost model developed at the Battelle National Laboratories. 5 Unfortunately, this model is based on observations of drilling costs, primarily for liquid/vapor dominated geothermal systems, at somewhat shallow depths (less than $10000 \mathrm{ft}$ ), and for drilling in material other than impermeable granite. Cost functions based on Geocost data are developed in App. A. Cost functions for medium rock hardness are used for basement depths of 2400 feet, and those for hard rock hardness (App. A) are used for depths in excess of basement depth. Resulting cost estimates are given in column 3 of Table II.

3. Republic Geothermal, Inc. (RGI). RGI conducted an in-depth study of drilling costs for HDR reservoirs for the Lab in 1979.6 This study is the most comprehensive work concerning drilling costs--applicable to HDR specifically--in existence to date (App. B). Using a basement depth of $2400 \mathrm{ft}$ (comparable to the Lab data but not comparable to the WFC site with basement depth of 9000 feet), drilling cost estimates from the RGI model are given in column 4 of Table II. Cost ranges for 10000 to $15000 \mathrm{ft} \mathrm{drilling}$ depths reflect contingency factors on drilling time in permeable/impermeable rock of $50 \% / 15 \%$ to $100 \% / 100 \%$.

4. Other Geothermal Projects (OGP). Drilling costs for a number of DOE sponsored and privately funded drilling projects are plotted in Fig. 2. Loglinear curves have been fitted to these points, and resulting comparative cost estimates for the range 2500 to $10000 \mathrm{ft}$ are given in column 5 of Table II.

Data in Table II and Fig. 2 serve to highlight the uncertainties surrounding efforts to estimate drilling costs for our HDR system. Two related observations in this regard are particularly relevant. First, widely varyir drilling costs have been incurred for drilling wells to roughly equal depths. 
TABLE II

ALTERNATIVE DRILLING COST ESTIMATES

(2 400-ft depth to basement) ${ }^{\mathrm{a}}$

Cost Estimate for a Pair of Wells (106 1980 dollars)

Approximate Vertical Drilling
Depth

2500

5000

7500

10000

12500

15000$$
\text { The } L a b b
$$$$
0.9^{e}
$$$$
--
$$$$
-
$$

$10.2^{j}$

$--$

$18.0^{1}$
Geocostc

0.5

1.3

3.1

7.5

$--$

$-$
RGI

3.2
Other Geothermal Projects Mean Costs d

$0.9^{f}$

2.49

$7.6^{\mathrm{h}}$

6.0

$12.8^{i}$

$7.7-11.9^{k}$

$10.6-17.1^{k}$

$12.9-20.8^{k}$

aDepth to basement for the Lab's Fenton Hill drilling site; applied to Geocost and RGI estimates for drilling costs.

bThe Lab costs adjusted to 1980 dollars: $7.5 \% / \mathrm{yr}$ to $1978 ; 38.3 \%, 1978$ to $1979 ; 27.2 \%, 1979$ to 1980 .

CAppendix Table A-1. Equation C (Medium) for 2400 feet to basement; C (Hard) for drilling depth in excess of 2400 feet. Estimate doubled for well pair costs.

dFigure 2 .

e Double the cost of the Lab's GT-l well drilled in 1973.

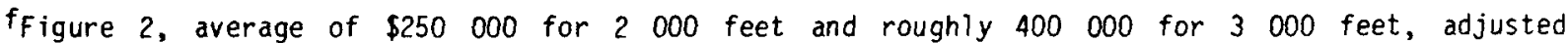
(\$27.2\%) for 1980 dollars; doubles for well pair cost.

GAverage of 11 costs (Figure 2) in the 4000 - to $6000-\mathrm{ft}$ interval, ranging from $\$ 0.3$ million to $\$ 2.2$ million; adjusted $(\$ 27.2 \%)$ to 1980 dollars. Result, $\$ 1.2$ milition for one well, doubled for well pair cost.

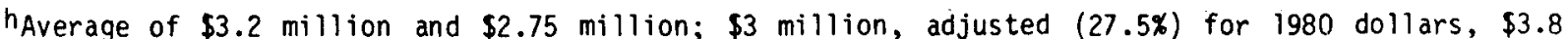
million, doubled for well pair cost.

iLinear extrapolation of 5000 to 7500 costs to 7500 to $10000 \mathrm{ft}$.

jLab costs for GT-2 and EE-1 wells.

kContingency factors of $50 \%$ to $15 \%$ respectively for drilling time in permeable-impermeable rock apply to lower estimate; $100 \%$ to $100 \%$ contingency factors apply to higher estimate.

${ }^{1}$ Lab costs for EE-2 and EE-3 we $11 \mathrm{~s}--14400 \mathrm{ft}$. 


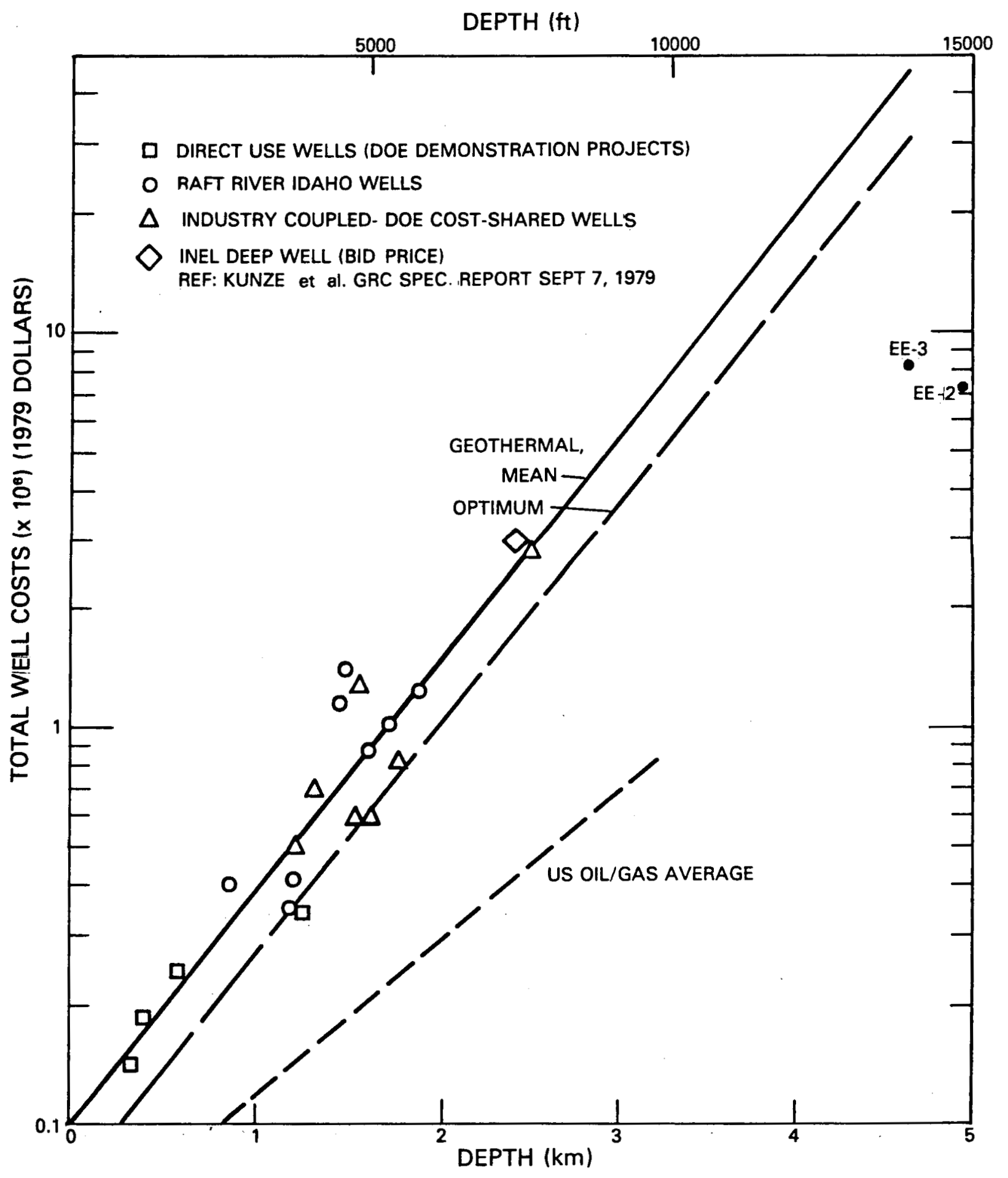

Fig. 2. Typical drilling costs for geothermal wells. 
leferring to Fig. 2, for wells drilled to depths at the 5000 to 6000 feet level, costs have varied from some $\$ 550000$ to $\$ 2.2 \mathrm{million}$. Referring to data given in Table II, cost estimates (RGI and Geocost) vary markedly (except for depths around $10000 \mathrm{ft})$; cost data based on actual, past drilling activities (the Lab and OGP) also exhibit wide variations.

Second, but inextricably related to the above, it would seem that the wide variations in drilling costs result from the many unanticipated events that one may encounter in drilling deeper wells, particularly in granite. Engineers of the Lab relate a phalanx of experiences involving problems in angle build-up and drilling pipe that broke in the well bores, all of which have the effect of adding substantial rig time and costs to the drilling operation. 'The potential for such unanticipated events is explicitly accounted for in the RGI model by substantial allowances for drilling contingencies on the order of 50\% plus (App. B). The difference between OGP'S "everything goes we 11 " and "mean cost" averages is 55\% to 60\% (Fig. 2).

Thus, any effort to estimate drilling costs as simply a function of depth must in some way consider the potentially significant variation in drilling costs (to virtually any depth) that attend contingencies, as well as the general uncertainty that surrounds the drilling cost issue which is primarily attributable to our limited experience in drilling to great depths in crystalline rock. This problem is treated in the following manner in this work. In an effort to be conservative, the RGI drilling cost function (App. B) is used inasmuch as estimated RGI costs are higher than Geocost estimates in the 10 000-ft $r$ ange of drilling depths relevant for this study. Included as parameters in the RGI drilling cost model are contingency factors for drilling time in permeable material (9000 ft in the WFC application) and in basement rock (only 2000 to $3000 \mathrm{ft}$ in this application). Reflecting the predominance of drilling in permeable material in this particular case study, the following contingency factors are used for a Base Case analysis and for sensitivity analyses.

Contingency Factor for Drilling

Permeable material

Impermeable basement rock
Contingency Factors

\begin{tabular}{|c|c|c|}
\hline \multirow[b]{2}{*}{$\begin{array}{c}\text { Base Case } \\
(\%)\end{array}$} & \multicolumn{2}{|c|}{ Sensitivity Analysis } \\
\hline & $\begin{array}{l}\text { S-1 } \\
(\%) \\
\end{array}$ & $\begin{array}{l}S-2 \\
(\%) \\
\end{array}$ \\
\hline 50 & 50 & 100 \\
\hline 15 & 50 & 100 \\
\hline
\end{tabular}


For the purposes of this work, uncertainties surrounding the estimat of drilling costs for any given depth of drilling, discussed above, are compounded by uncertainties as to the future levels of drilling costs. These latter uncertainties reflect the dramatic increase in drilling costs that has occurred since the 1973 oil embargo. Annual increases in real drilling costs-cost increases above average inflation rates--were almost $11 \%$ during the 1974 to 1979 period (Table III); nominal drilling costs increases at $18.5 \%$ per year during this period. Whereas initial drilling costs are based on 1980 costs in this work, re-drilling options, discussed above, will occur in the future (over the 30-year planning horizon) and, as such, costs for ré-drilling must reflect expected increases in real, inflation-free, drilling costs. Given the rapid increases in drilling costs noted above, the issue as to whether such rapid increases will continue into the future is of particular importance for this work.

Projections of future conditions are normally based on extrapolations from the past. One assumes that past trends will continue in a relatively stable fashion in the future. These procedures are highly questionable, however, when the recent past is characterized by anomalous disturbances, such as a period of war. Anomalous disturbances would seem to aptly describe the US economy during the post-embargo period 1973 to the present. Between 1973 and 1979, the general price level increased by 54\%;* oil prices during the brief, 4-year period 1976 to 1980 almost tripled, increasing from $\$ 10.72 / \mathrm{bbl}$ to $\$ 30.96 / \mathrm{bbl} . \star \star$ More relevant for this discussion, drilling costs per foot for a 11 'oil, gas and dry wells increased from a 1965 to 1973 average of $\$ 17.76$ to $\$ 46.25$ (1974 to 1979 average, Table IV).

In cases like this wherein recent years are atypical compared with longer-run historical trends, the analyst, in his efforts to project future conditions, must inquire as to the causes for observed, anomalous disturbances and address the likelihood that such disturbances may continue. To this end, it is instructive to consider the data given in Tables III through VI. Average drilling costs in nominal and constant 1979 dollars are given in Table $V$. During the 1960 to 1970 period, drilling costs rose and fell but remained

*See GNP deflator for 1973 and 1979, Table VI.

**Wholesale prices for refined No. $60 i 1$; prices are for 1976 average an January 1981 (Ref. 7). 
TABLE III

AVERAGE ANNUAL COMPOUND GROWTH RATES FOR DRILLING COSTS

\begin{tabular}{cc}
\multicolumn{3}{c}{$\begin{array}{c}\text { Compound Annual Rate } \\
\text { of Increase in Drilling Costs } \\
(\% \text { of dollars) }\end{array}$} \\
\hline Current & $\begin{array}{c}\text { Real } \\
1979\end{array}$ \\
\hline 0.7 & -0.9 \\
3.8 & 0.9 \\
7.0 & 2.6 \\
8.0 & 2.5 \\
6.9 & 1.0 \\
15.3 & 8.1 \\
18.5 & 10.8 \\
4.3 & 0.9
\end{tabular}

SOURCE: Table $V$ and $V I$.

Period

1960 to 1965

1960 to 1970

1965 to 1970

1965 to 1973

1970 to 1973

1970 to 1979

1974 to 1979

1960 to 1973

TABLE IV

AVERAGE DRILLING COSTS AND STANDARD DEVIATIONS

\begin{tabular}{|c|c|c|c|c|}
\hline \multirow[b]{2}{*}{ Period } & \multicolumn{2}{|c|}{$\begin{array}{l}\text { Average Drilling Costs } \\
\text { (dollars per ft) }\end{array}$} & \multicolumn{2}{|c|}{$\begin{array}{c}\text { Standard Deviation } \\
\text { (dollars) }\end{array}$} \\
\hline & Current & $\begin{array}{r}\text { Real } \\
(1971) \\
\end{array}$ & Current & $\begin{array}{r}\text { Real } \\
(1970) \\
\end{array}$ \\
\hline 1960 to 1965 & 13.03 & 29.79 & 0.48 & 0.88 \\
\hline 1960 to 1970 & 14.76 & $31: 09$ & 1.37 & 1.19 \\
\hline 1965 to 1970 & 16.27 & 32.12 & 1.22 & 1.02 \\
\hline 1965 to 1973 & 17.76 & 32.60 & 1.49 & 1.03 \\
\hline 1974 to 1979 & 46.25 & 53.22 & 3.29 & 2.74 \\
\hline
\end{tabular}

SOURCE: Data in Table $V$. 
TABLE V

DRILLING COSTS IN THE US, 1960 to 1979

\begin{tabular}{|c|c|c|c|c|c|}
\hline \multirow[b]{3}{*}{ Year } & \multirow{3}{*}{$\begin{array}{c}\text { Average } \\
\text { Depth } \\
(\mathrm{ft}) \\
\end{array}$} & \multirow{2}{*}{\multicolumn{2}{|c|}{$\begin{array}{c}\text { All 0i1, Gas, and } \\
\text { Dry Wells } \\
\text { (dollars per foot) } \\
\end{array}$}} & \multicolumn{2}{|c|}{$\begin{array}{l}\text { Per Cent Increase from } \\
\text { Previous Year }\end{array}$} \\
\hline & & & & & \\
\hline & & Current & 1979 & $\begin{array}{l}\text { Current } \\
\text { Dollars } \\
\end{array}$ & $\begin{array}{l}1979 \\
\text { Dollars } \\
\end{array}$ \\
\hline 1960 & 4156 & 13.01 & 30.83 & & \\
\hline 1961 & 4216 & 12.85 & 30.19 & -1.3 & -2.1 \\
\hline 1962 & 4309 & 13.31 & 30.69 & 3.6 & 1.7 \\
\hline 1963 & 4312 & 12.69 & 28.81 & -4.7 & -6.2 \\
\hline 1964 & 4326 & 12.86 & 28.76 & 1.3 & -0.02 \\
\hline 1965 & 4415 & 13.44 & 29.45 & 4.5 & 2.4 \\
\hline 1966 & 4558 & 14.95 & 31.69 & 11.2 & 7.6 \\
\hline 1967 & 4526 & 15.97 & 32.87 & 6.8 & 3.7 \\
\hline 1968 & 4849 & 16.83 & 32.32 & 5.4 & -2.1 \\
\hline 1969 & 5007 & $17.56^{\circ}$ & 32.94 & 4.3 & 2.3 \\
\hline 1970 & 5022 & 18.84 & 33.56 & 7.3 & 1.9 \\
\hline 1971 & 4949 & 19.03 & 32.27 & 1.0 & -3.9 \\
\hline 1972 & 5026 & 20.76 & 33.80 & 9.1 & 4.7 \\
\hline 1973 & 5146 & 22.50 & 34.62 & 8.4 & 2.4 \\
\hline 1974 & 4843 & 28.93 & 40.60 & 28.6 & 17.3 \\
\hline 1975 & 4761 & 36.99 & 47.34 & 27.9 & 16.6 \\
\hline 1976 & 4643 & 40.46 & 49.23 & 9.4 & 4.0 \\
\hline 1977 & 4819 & 46.81 & 53.82 & 15.7 & 9.3 \\
\hline 1978 & 4875 & 56.63 & 60.61 & 21.0 & 12.6 \\
\hline 1979 & 4925 & 67.70 & 67.70 & 19.5 & 11.7 \\
\hline
\end{tabular}

relatively stable in the range of $\$ 13.00$ to $\$ 16.00$ per foot $(\$ 30$ to $\$ 32$ in constant 1979 dollars; see Table IV). During this eleven-year period, real, inflation-free drilling costs increased at the modest rate of $0.9 \%$ (Table III); during the shorter, 1960 to 1965 period, drilling costs fell at $0.9 \%$ per year (Table III). Moving into the 1970s, drilling costs remained relatively stable, increasing (in real value) but some $1.0 \%$ per year during the 1970 to 19x 
TABLE VI

GNP PRICE DEFLATOR FOR THE US, 1960 to 1979

\begin{tabular}{|c|c|}
\hline Year & GNP Price Deflator \\
\hline 1960 & 68.7 \\
\hline 1961 & 69.3 \\
\hline 1962 & 70.6 \\
\hline 1963 & 71.7 \\
\hline 1964 & 72.8 \\
\hline 1965 & 74.3 \\
\hline 1966 & 76.8 \\
\hline 1967 & 79.1 \\
\hline 1958 & 82.5 \\
\hline 1969 & 86.8 \\
\hline 1970 & 91.4 \\
\hline 1971 & 96.0 \\
\hline 1972 & 100.0 \\
\hline 1973 & 105.8 \\
\hline 1974 & 116.0 \\
\hline 1975 & 127.2 \\
\hline 1976 & 133.7 \\
\hline 1977 & 141.7 \\
\hline 1978 & 152.1 \\
\hline 1979 & 165.5 \\
\hline
\end{tabular}

SOURCE: Ref. 9.

period. Viewed over the long run, 1970 to 1973, inflation-free drilling costs increased at only some $0.9 \%$ per year.

As one would surely expect, a sharp break with historical trends for increases in drilling costs attended the 1973 oil embargo. The more than tenfold change in the increase in real drilling costs--from 0.9\%, 1970 to 1973, to $10.8 \%$, 1974 to 1979--reflected corresponding changes in those factors that determine the level of drilling costs (see App. C for a discussion of these factors); the general price level (including oil costs) and associated machinzery costs, drilling depths (which obviously affect drilling costs per foot), and the overall competitive demand for drilling rigs (as manifested by the 
annual number of wells that are drilled). Thus, the general price le increased at an annual rate of $7 \%$ during 1974 to $1979--$ double the $3.4 \%$ rate that was obtained during the 1960 to 1973 period; whereas real oil prices fell between 1960 and $1970(-1.3 \%$ /year), they rose at an annual rate of $6.9 \%$ between 1970 and 1979 (Ref. 9, Table 1034). The real, inflation-free annual rate of increase in machinery costs was $3.2 \%$ between 1974 to 1979 , more than four times greater than the $0.7 \%$ rate that occurred during the 1960 to 1970 decade. Average drilling depths for $0 i 1$ and gas wells during the 1974 to 1979 period increased by $4 \%$ over those in the 1960 to 1973 period--from $4630 \mathrm{ft}$ to $4811 \mathrm{ft}$. Most importantly, the annual rate of change in the number of new oil wells drilled per year in the US was 5.3\% during 1968 to 1979, in sharp contrast with -5.3 during 1960 to 1970 --that is, the drilling industry shifted from a declining industry in the 1960s to a growth industry in the 1970s.

The break in historical trends for factors relevant to estimates for drilling costs is made manifest by the data given above. At issue, of course, is the question of whether these recent, post-1973 trends are likely to continue. As discussed in the following section, real oil prices are not expected to increase at anything like the $6.9 \%$ rate that characterized the 1970 to $197^{\prime} 9$ period. Estimates for real increases in 017 prices on the order of $3 \% / y e a r$ are common in the literature although more recent estimates put increases in real oil prices at around $1 \%$ per year. While too little time has passed for an accurate assessment of current anti-inflation policies of the US government, inflation rates during the first half of 1981 are well below the double-digit rates of 1979 and 1980. It would be difficult to judge the probable impact of reduced rates of increase in oil prices on drilling activity (new wells drilled); however, the stabilization of profits that must attend reduced rates of increase in real oil prices will undoubtedly give rise to more stable exploratory and development activities and, therefore, annual changes in drilling activity.

To the authors' minds, present trends would seem to imply the long-run stabilization of factors that underlie changes in real drilling costs, in which case an annual increase in real drilling costs ak in to the 1960 to 1973 average rate of $1 \%$ per year would be suggested--a rate somewhat lower than real increases in oil prices. Given the sensitivity of real drilling costs to general inflationary pressures (see App. C), however, and the uncertainty surroundinf future inflation rates, it is desirable to base results from our study of HDR 
sor space heat on conservative assumptions compared to these uncertainties. Therefore, real drilling costs are assumed to increase at an annual rate of $4.34 \%$ in our base case--a rate that approximated the 1960 to 1979 rate that includes the post-embargo period. For sensitivity analyses, however, a rate of $3 \%$ is used (which is our base case rate of increase in real oil prices, discussed below) as is a higher, 6\% rate (approximates the shorter-run, 1969 to 1979 rate).

C. $0 i 1$ Costs

Annual rates of increase in real oil prices are relevant for two important measures used in this study. As shown in Sec. II above, gross benefits attributable to the HDR system are based on oil costs over 30 years, which the WFC would pay if it used its existing, conventional system. Further, for periods over the base case 30-year planning horizon (discussed below) wherein the preheat optin is used, appropriate real oil costs are required for costing the preheat option.

Reference has been made above to the increase in oil prices during the post-embargo period. Such increases are put into historical perspective by the following data.

\begin{tabular}{lc} 
Period & $\begin{array}{c}\text { Compared Annual Rate of } \\
\text { Increase in Real 0i] Prices } \\
(\%)\end{array}$ \\
\hline 1960 to 1970 & -1.3 \\
1960 to 1979 & 2.5 \\
1970 to 1979 & 6.9
\end{tabular}

Thus, as mentioned above, the declining real price of oil during the 1960 s contrasts sharply with the $6.9 \%$ annual rate of increase in real oil prices that occurred during the 1970s.

Somewhat surprisingly, however, there appears to be general consensus among analysts concerning likely rates of increase in future real oil prices, namely, that such rates will decline markedly; examples include the following: 


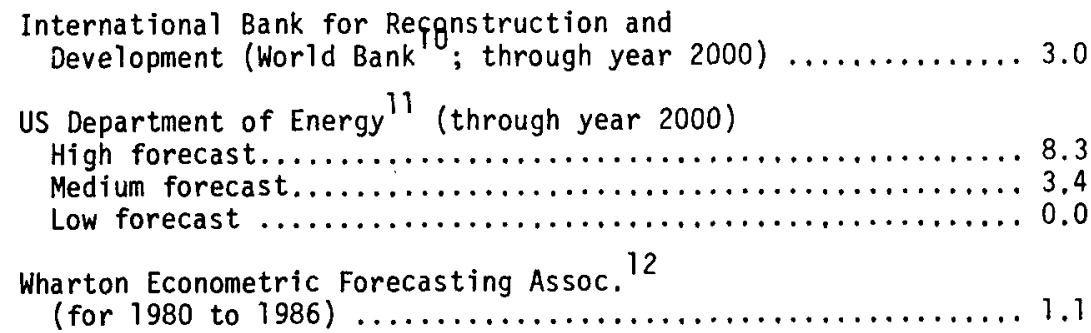

In addition to the above, recently announced studies by US oil companies suggest long-term increases in real $0 i 1 \mathrm{prices}$ at the $1 \% /$ year level.

Opting. again for conservatism, a real rate of increase in oil prices of $3 \%$ per year will be used for this study's base case; sensitivity analysis will be conducted, however, using rates of $2 \%$ and $4 \%$.

D. Discount Rates

The choice of an appropriate real rate of discount is, has been, and continues to be a subject for debate in the economics profession (Refs. 13-14). Little is to be gained by continuing that debate in this work. The base case discount rate to be used here is the rate mandated for use by Federal agencies involved in planning for rational uses of land and water resources by the Water Resources Council ${ }^{13-14}$ (WRC), namely, $71 / 4 \%$. Whereas, for the purpose of evaluating public projects, the WRC rate of $71 / 4 \%$ is criticized as being high for use as a real discount rate, such a rate is consistent with real earnings rates in many non-agricultural industries in the US.* Further, there is intuitive appeal in assigning higher rates of earnings as being required for relatively new technologies. Therefore, for sensitivity analyses, a higher rate of $10 \%$ is used as is a lower rate of $4 \%$.

E. Time Horizons

In general, a 30-year time or planning horizon is used in this work. The choice of 30 years is, of course, arbitrary: experience with wellbores for HDR systems is obviously too limited for precise estimates of the probable useful lifetime of these boreholes. Thirty years is simply regarded as a reasonably conservative estimate for HDR system lifetime at present by engineers at the $L a b$.

*For real rates of return in US industries, see Ref. 15 . 
If, for any of the cases analyzed below, re-drilling occurs more than once during the thirty years, the assumed 30-year lifetime becomes ultra-conservative for the following reason. Suppose that re-drilling occurs in years 10 and 20. As explained in Section III (see Fig. 2), the following pattern of drilling would take place:

(1) two wells--the production well and the deeper, injection well--are drilled at the beginning of year 1 ;

(2) in year 10, the initial production well is plugged, a new production well is drilled; and

(3) in year 20, the 20-year-01d injection we 11 is plugged and a new injection production well is drilled.

From the above, it is clear that at the end of our 30-year planning horizon the HDR wells are not 30 years old: the injection well is 10 years old and the production well--drilled in year 10--is 20 years old; the average lifetimes of the two HDR wells and the lifetime of the HDR reservoir at the end of 30 years are but 15 years and 10 years, respectively.

The variable system lifetime problem that arises when re-drilling takes place may seriously bias feasibility measures for the HDR system.* One could deal with this bias in one of at least two different ways. First, one could introduce a "terminal value function" that would attribute benefits to the useful system that exists at the end of year 30. Second, one could vary the planning horizon in such a way that the planning horizon coincides--as best as possible--with a fully depreciated pair of HDR wells. This latter approach is made difficult when the preheat option is not used inasmuch as reservoir temperature declines to a temperature below $74^{\circ} \mathrm{C}$ (our design temperature for the space heat system) re-drilling is always required before a pair of wells have been used for 30 years.

Regrettably, time and resource limitations for this phase of research dictate the necessity for leaving the optimal time horizon problem as an important topic for future research. In this work, the time horizon problem is treated in the following, admittedly inadequate manner. In all cases other than those where re-drilling takes place in 27 to 30 years, a 30-year time horizon is used. If re-drilling occurs in say, for example, year 27, a comparison is made of benefits and costs associated with the 30 -year system

*The nature of the bias is to undervalue the HDR resource. 
and a 27-year system. If net benefits for the 27-year system exceed those for the 30-year system, the 27-year time horizon is used. Thus, we leave as an open question the appropriate time horizon in cases where re-drilling occurs in years prior to year 27 and, for these cases, the reader should be alerted to the potential conservative bias attending feasibility measures in those cases.

F. Other Economic Factors

There are three additional sets of costs that warrant mention here. The first of these is capital costs for surface equipment needed for a space heat system, primarily including distribution piping systems, heat exchangers, and boiler equipment (for the preheat option). The WFC is in the process of replacing parts of its existing pipe system for a partial conversion to a hot water heating system. Given that, our comparative analyses are based on the WFC's current steam system. Costs for all new pipes and heat exchangers associated with the HDR hot water system must be charged to the HDR system. Based on discussions with WFC engineers, these costs would range between $\$ 2$ million and $\$ 2.5 \mathrm{million}$; the midpoint, $\$ 2.25 \mathrm{million}$, will be used in this work.

A second set of costs includes costs associated with operation and maintenance (O\&M) of the space heat system. Discussion with engineers at the $L a b$ and the WFC suggest that there is not a deductive reason to expect that annual 0\&M costs would necessarily be higher for the existing, conventional system than for the HDR system, or vice versa. Because net benefits attributable to the HDR system are the difference between avoided costs of the conventional system and HDR system costs, the difference is unaffected by 0\&M costs. Thus, 0\&M costs are simply not treated in this work.

The third set of costs that should be mentioned here are those associated with exploratory drilling, in cases where such activities are required. Considerable exploratory drilling has taken place in the WFC area, in which case such costs are not included here. Again, future studies concerning the use of HDR geothermal resources for space heat applications in other areas may require a consideration of costs associated with exploratory drilling.

In closing these discussions of economic factors relevant for the HDR system, we note that the nature of the case study of NASA's WFC--a Government installation--is such that the wide range of taxes, depreciation/depletion allowances, and business/energy tax credits appropriately considered for the private sector do not apply in this case. 
V. IMPORTANT TECHNICAL CONSIDERATIONS RELEVANT TO THE HDR SYSTEM AND BASE CASE ASSUMPTIONS

A. Overview

In this section attention is focused on two sets of technical considerations that may be of particular importance in determining the feasibility of HDR geothermal resources for space heat uses: reservoir design (number of fractures), well flow rates, and temperature drawdown; depth to basement and geothermal temperature gradients. Following these discussions, in Sec. D, economic and technical considerations are brought together to the end of structuring assumptions to be used for a base case analysis of HDR resources used for space heating at the WFC along with changes in these assumptions that will be used for sensitivity analyses.

B. Reservoir Design, Well Flow Rates, and Temperature Drawdown

Temperature drawdown refers to the process by which the surface area of the hot, dry rock reservoir cools as water passes across this surface area (Ref. 1, Chap. II). Among other things, such as the thermal conductivity of the rock, the rate of cooling in the reservoir--temperature drawdown--is determined by the rate at which water is passed through the reservoir (the well flow rate), the surface area of the reservoir, and the length of time that water (at the aforementioned flow rate) has been passing through the reservoir.

The method used in this work for estimating temperature drawdown is based on estimation techniques developed at the Lab and is explained in some detail in App. D. In general terms, reservoir temperature at the end of any year $T(\tau)$, relative to initial reservoir temperature, $T_{0}$, is given by the following relationships.

$$
\begin{aligned}
& T(\tau)=T_{i}+\left(T_{0}-T_{i}\right) \operatorname{erf}(Z) \\
& T(\tau)-T_{0}=\left(T_{0}-T_{i}\right)[\operatorname{erf}(Z)-1] \\
& Z=\sqrt{\frac{\left(g p C_{r}\right)}{t} \frac{S}{m_{w e 11} C_{w}}}
\end{aligned}
$$

where 


$$
\begin{array}{ll}
T_{i} & =\text { reinjection temperature, } \\
T_{0} & =\text { initial reservoir temperature, } \\
C_{W} & =\text { heat capacity of water, } 4200 \mathrm{~J} /(\mathrm{kg} \mathrm{K}), \\
C_{r} & =\text { heat capacity of granite, } 1000 \mathrm{~J} /(\mathrm{kg} \mathrm{K}), \\
\mathrm{p} & =\text { rock density }\left(2500 \mathrm{~kg} / \mathrm{m}^{3}\right), \\
\mathrm{g} & =\text { thermal conductivity of granite }(3.0 \mathrm{~W} / \mathrm{m} \mathrm{K}), \\
\mathrm{t} & =\text { cumulative time }(\mathrm{sec}) \text { since the establishment of the reservoir, } \\
\mathrm{S} & =\text { surface area of the reservoir, and } \\
\mathrm{m}_{\mathrm{we}} 11 & =\text { well flow rate }(\mathrm{kg} / \mathrm{sec}) .
\end{array}
$$

Because the error function increases as the numer $Z$ increases, 16 temperature drawdown [the right-hand side of Eq. (2)] increases with smaller reservoir surface areas, with the passing of time ( $t$ in the denominator $z$ ), and with larger well flow rates.

The relationships given by Eqs. (1) and (3) represent the best available method for presently estimating temperature drawdown. Therefore, these relationships are used for base case analyses of the HDR system in this work. Given our limited experience in testing estimates drawn from Eqs. (1) and (3) against actual drawdown rates in reservoirs with varying surface areas and well flow rates, it is desirable to consider the sensitivity of feasibility measures for the HDR system to alternative rates of temperature drawdown. With no viable alternative methods for estimating this relationship, the choice of other drawdown rates must be arbitrary. In this work we opt for a conservative alternative and, as a sort of sensitivity analyses, will consider the feasibility of the HDR system for the WFC case study where drawdown rates estimated by Eqs. (1) and (3) are simply doubled.

As shown above, the well flow rate is important in determining the rate of temperature drawdown. For the purpose of analyzing the HDR system, it then becomes important to use the minimal well flow rate (thereby reducing temperature drawdown) whenever possible. The choice of well flow rates in this study of the WFC is determined in the following manner.

During years when reservoir temperatures exceed the design temperatura of $74^{\circ} \mathrm{C}$, the design flow rate of $52.36 \mathrm{~kg} / \mathrm{sec}$ (at a temperature of $74^{\circ} \mathrm{C}$ ) can 
satisfied by mixing water from the space heat systems return flow, $52.36 \mathrm{~kg} / \mathrm{sec}$ at a temperature of $62.89^{\circ} \mathrm{C}$, with water from the HDR reservoir. Thus, for example, if, for a given year, reservoir temperature is $100^{\circ} \mathrm{C}$, the well flow rate is given by:

$$
m_{\text {we11 }}=\frac{(52.36 \mathrm{~kg} / \mathrm{sec})\left(74^{\circ} \mathrm{C}-62.89^{\circ} \mathrm{C}\right)}{100^{\circ} \mathrm{C}-62.80^{\circ} \mathrm{C}}=15.68 \mathrm{~kg} / \mathrm{sec}
$$

Thus, $15.68 \mathrm{~kg} / \mathrm{sec}$ of the system's return flow of $52.36 \mathrm{~kg} / \mathrm{sec}$ is injected into the HDR reservoir, and $36.68 \mathrm{~kg} / \mathrm{sec}$ (at $62.89^{\circ} \mathrm{C}$ ) is mixed with HDR fluid at $100^{\circ} \mathrm{C}$ to provide system requirements of $52.36 \mathrm{~kg} / \mathrm{sec}$ at $74^{\circ} \mathrm{C}$.

It must be noted that this method for determining a varying well flow rate, in terms of the error function, Eq. (1), used to calculate temperature drawdown, has the effect of overestimating temperature drawdown. Because reservoir temperatures monotonically decline from initial temperatures,

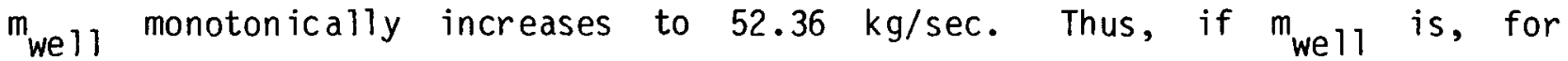
example, $30 \mathrm{~kg} / \mathrm{sec}$ in the fifth year of operation and was less than $30 \mathrm{~kg} / \mathrm{sec}$ in the earlier four years, the use of $30 \mathrm{~kg} / \mathrm{sec}$ in Eqs. (1) and (3) results in an estimate for temperature drawdown that would have occurred if $m_{\text {well }}$ were $30 \mathrm{~kg} / \mathrm{sec}$ for the entire five years--lower flow rates in earlier years are not considered. This overestimate is unavoidable inasmuch as Eqs. (1) and (3) cannot be used for varying flow rates; one simply must recognize the bias in temperature drawdown rates that may result when varying flow rates are used.* During years where reservoir temperature is at or below $74^{\circ} \mathrm{C}$ (as in the preheat option), the well flow rate is set at $52.36 \mathrm{~kg} / \mathrm{sec}$.

Also pointed out above was the dependence of temperature drawdown on reservoir design--the size, or surface area, of the HDR reservoir. A part of the Lab's research concerning reservoir design, in terms of affecting surface area, focuses on the multiple fracture concept demonstrated in Fig. 3 . Each of the fractures depicted in Fig. 3 is assumed to have a diameter of $360 \mathrm{~m}$ ( $1181 \mathrm{ft}$ ); the horizontal distance between fractures is $164 \mathrm{ft}$. A given total well flow rate is distributed evenly between the fractures by a system

*A computer model, DRAW-D, has been constructed at Los Alamos to simulate reservoir temperature drawdowns when well flow rates vary over time. This model is still under development, but preliminary results verify that the calculations in this report significantly overestimate temperature drawdown. The net HDR system benefits are always underestimated for the WFC case reported here because they always have monotonically increasing flow rates. 


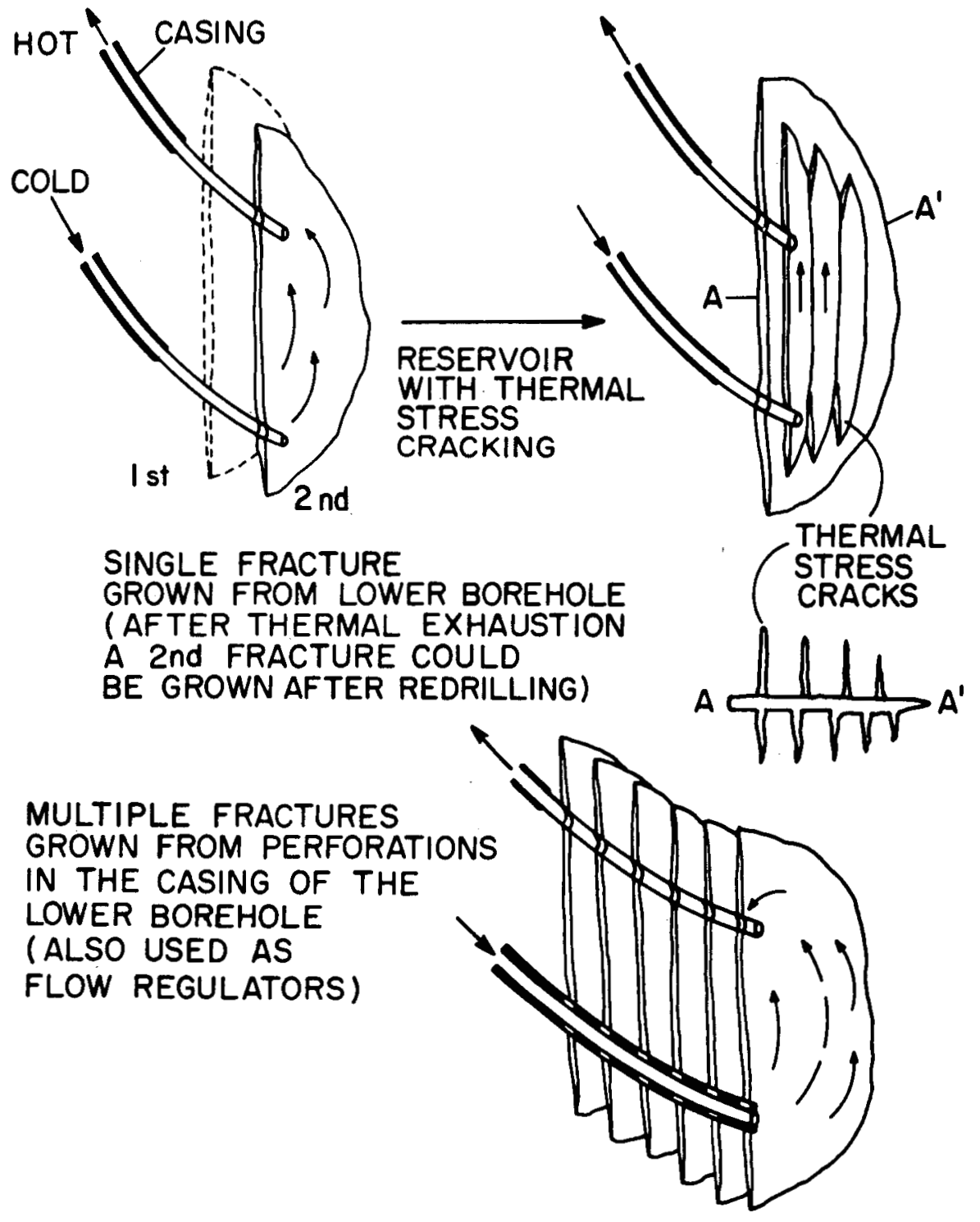

Fig. 3. Schematic of multiple-fracture concept. 
of valves. Each fracture adds an effective surface area to the HDR reservoir system of 1.1 million square feet.

Analyses concerning the feasibility of the HDR system for the WFC case study will include two specific issues related to reservoir surface area, as represented by the number of fractures in the HDR reservoir. First, the issue of an optimum number of fractures (optimum reservoir surface area) will be considered; the optimum number of fractures is that number that minimizes costs for the HDR system. Second, attention will be focused on the minimum number of fractures required for the HDR system to be feasible (system benefits greater or equal to system costs); this latter question is of interest in terms of defining minimum design requirements for a feasible HDR system.

C. Depth to Basement and Geothermal Temperature Gradients

The relevance of depth to basement rock for HDR system costs is immediately obvious; it establishes a lower bound on drilling depths. In the WFC case study, depth to basement is $9000 \mathrm{ft}$. With minimum drilling in basement rock of $250 \mathrm{ft}$ before directional drilling can be initiated, and some $2023 \mathrm{ft}$ required to establish drilling angles and establish the fracture, minimum drilling depth for the WFC case study to establish one fracture is $11273 \mathrm{ft}$.*

The average geothermal temperature gradient in the WFC area is $30^{\circ} \mathrm{C} / \mathrm{km}$ of vertical depth. For other applications, of course, this gradient may be very different. Common gradients found across the US will vary from $20^{\circ} \mathrm{C} / \mathrm{km}$ to $70^{\circ} \mathrm{C} / \mathrm{km}$ and higher. To achieve a given reservoir temperature, the higher the geothermal gradient the shallower is the required drilling depth and, therefore, the less are drilling costs, all else equal.

The major all-else-equal consideration is, of course, depth to basement. Thus, to establish a reservoir with initial temperatures of $95^{\circ} \mathrm{C}$ in an area with a geothermal temperature gradient of $40^{\circ} \mathrm{c} / \mathrm{km}$, drilling would extend roughly to two kilometers (6562 ft; with a $15^{\circ} \mathrm{C}$ surface temperature). With depth to basement of $9000 \mathrm{ft}$ (as at WFC), drilling to depths well in excess of two kilometers would be required.

From the above it becomes clear that meaningful sensitivity analyses for geothermal gradients must be combined with those for depth to basement. Thus, our analyses of base case conditions (9 $000 \mathrm{ft}$ depth to basement and $30^{\circ} \mathrm{C} / \mathrm{km}$ gradient) are extended to the following cases for sensitivity analyses.

*See App. B. 
Depth to

Basement

(ft)

2400

5700

9000
Geothermal

Gradient

$\left({ }^{\circ} \mathrm{C} / \mathrm{km}\right)$

$25,30,35,40$

$25,30,35,40$

$25,30,35,40$

\section{Base Case Assumptions and Sensitivity Analyses}

Discussions above, along with those in Sec. III, provide the reader with the rationale underlying assumptions used by the authors for this case study of space heat applications for HDR geothermal resources at the WFC. Drawing from these earlier discussions, assumptions used for the base case analysis of the HDR system are summarized in Table VII; an overview of parameter values that are to be subjected to sensitivity analyses is given in Table VIII.

\section{TABLE VII}

BASE CASE ASSUMPTIONS

\section{Economic Assumptions}

1980 fuel costs for conventional steam system $\$ 879152$

(26 667 bbl No. 6 oil at $\$ 33.00 / \mathrm{bbl}$ ).

30-year planning horizon: $71 / 4 \%$ real discount rate.

Annual rate of increase in real oil prices $3 \%$, drilling costs.

RGI drilling costsa with contingency factors: $50 \%$ (permeable material) and $15 \%$ (basement rock).

Plugging costs: $\$ 358$ 160/operation.

Pipe/heat exchanger costs: $\$ 2.25$ million.

Technical Assumptions

Depth to basement: $9000 \mathrm{ft}$.

Geothermal gradient: $30^{\circ} \mathrm{C} / \mathrm{km}$.

Temperature drawdown (App. D).

Well flow rate: varied as required.

Fracture diameter: 360 meters; spacing: $164 \mathrm{ft}$.

Number of fractures: determined as the optimal number.

Btu requirement for WFC: $72.878 \times 10^{9}$.

asee App. B. 
Economic Parameters:

Rea] discount rate: $4 \%, 10 \%$.

Annual increase in real oil prices: $2 \%, 4 \%$ in drilling costs: $3 \%, 6 \%$.

RGI drilling costs with contingency factors: permeable material: $100 \%$

bas ement rock: $50 \%, 100 \%$

Technical Parameters:

Depth to basement (ft)/geothermal gradient $\left({ }^{\circ} \mathrm{C} / \mathrm{km}\right)$ comb inations: $2400 /(25,30,35,40) ; 5700 /(25,30,35,40)$; $9000 /(25,30,35,40)$.

Temperature drawdown: double rate determined in Table VII.

Btu requirement: $109.227 \times 109$ (50\% higher than base case; $36.709 \times 10^{9}$ (50\% lower than base case).

TABLE IX

FIXED SYSTEM CHARACTERISTICS (WFC)

Energy Consumption for Heating Systems (x $\left.10^{9} \mathrm{Btu}\right)$

Conventional Steam Hot Water

\begin{tabular}{lcc} 
Heating and constant use: & 69.34 & 69.34 \\
Losses & & \\
\hline Boiler & 32.26 & 14.56 \\
Feed water & 11.29 & 5.10 \\
Distribution line & 48.39 & 3.47
\end{tabular}

NOTE: Flow requirements is $52.36 \mathrm{~kg} / \mathrm{sec}$ at $74^{\circ} \mathrm{C}$ for each system. 
Energy-using characteristics of the WFC are summarized in Table IX. A detaileu description of cost items that underlie RGI estimates for drilling costs is provided in App. B.

\section{ANALYSIS OF THE BASE CASE}

A. Overview

Our analysis of base case results involves analyses of three sets of results. The first set concerns the optimal design of the HDR system as it relates to the choice of re-drilling or preheat options and reservoir design (number of fractures as a measure for surface area). The second set focuses on the minimum reservoir design case with base case assumptions. The third set concerns the minimum reservoir design case under base case assumptions wherein the preheat option is excluded.

Before beginning analyses of base case results, system costs and net benefits are evaluated at different initial drilling depths in an effort to approximate optimal initial drilling depths. Beginning with the minimum drilling depth for one fracture of $11273 \mathrm{ft}$ (see Sec. IV.B), initial drilling is increased to $19273 \mathrm{ft}$ in increments of $1000 \mathrm{ft}$ (Table X). As additional fractures are added, additional drilling is required to provide adequate separation of the fractures as shown in Table $x$. Given the many different drilling depths involved, the exposition is greatly simplified for the analyses that follow by describing initial drilling depths by the drilling depth index given in column 1 of Table $x$. Thus, for example, reference to initial drilling depth index 3 refers to a depth of $13273 \mathrm{ft}$ when 1 fracture is being considered, $13415 \mathrm{ft}$ when 2 fractures are being considered, and so on. Hopefully, the inconvenience to the reader of occasionally referring to depth indicies given in Table $X$ is offset by the neater exposition of issues central to this work--feasibility measures for the HDR space heat application. B. Feasibility and Optimal Design for the HDR System

Gross benefits to the HDR system--avoided costs associated with the WFC's existing, conventional steam system--are fixed at $\$ 15$ million for the base case (see Table I). An optimal system design is, therefore, the design that minimizes system costs--drilling costs plus $\$ 2.25$ million for pipes and heat exchangers.

Referring to Table XI, net benefits to the HDR system are maximized with

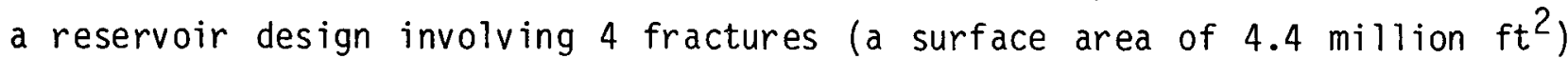


TABLE $X$

INITIAL DRILLING DEPTHS AND NUMBER OF FRACTURES

Initial Drilling

Depth with

Fractures (ft)

1

2

3

4

5

5

6

7

8

9

10
Initial Drilling Depth Index

\begin{tabular}{|c|c|c|c|c|c|c|c|c|}
\hline 1 & 2 & 3 & 4 & 5 & 6 & 7 & 8 & 9 \\
\hline 11273 & $12 \quad 273$ & $13 \quad 273$ & 14283 & 15273 & 16273 & $17 \quad 273$ & 18273 & 19273 \\
\hline 11475 & 12,415 & 13415 & 14415 & 15415 & 16415 & 17415 & 18415 & 19415 \\
\hline 11587 & 12587 & 13587 & 14598 & 15587 & 16587 & 17587 & 18587 & 19587 \\
\hline 11699 & 12699 & 13699 & 14700 & 15699 & 16699 & 17699 & 18699 & 19699 \\
\hline 11841 & 12841 & 13841 & 14941 & 15841 & 16841 & 17841 & 18841 & 19841 \\
\hline 11983 & 12983 & 13983 & 14093 & 15983 & 16983 & 17983 & 18983 & 19983 \\
\hline $12 \quad 125$ & & & & & & & & \\
\hline 12267 & & & & & & & & \\
\hline 12409 & & & & & & & & \\
\hline 12551 & & & & & & & & \\
\hline
\end{tabular}


and the use of the preheat option (rather than re-drilling); with this design, net benefits are $\$ 4.1$ million (gross benefits, $\$ 15$ million, less costs of $\$ 10.9$ million). This is to say that the WFC's space heat requirements over 30 years will cost $\$ 4.1$ million less if HDR resources are used, compared to costs associated with the UFC's conventional steam system. Drilling depth for this optimal solution is to $11699 \mathrm{ft}$, which is the minimum drilling depth for four fractures with depth to basement of $9000 \mathrm{ft}$. Initial reservoir temperature at that depth, $114.68^{\circ} \mathrm{C}$, is sufficient to provide all of the WFC's energy requirements for 29 years; the preheat option is used only in year 30 .

The time horizon, discussed above in section 3-E, is particularly relevant for this base case solution. The time path for reservoir temperatures in the base case is shown in Table XI. With an initial reservoir temperature of $114.68^{\circ} \mathrm{C}$, temperature drawdown is minimized by the use of low well flow rates in early years; * appreciable drawdown does not occur until year $3 . \star *$ Thus, reservoir temperature is above design temperature $\left(74^{\circ} \mathrm{C}\right)$ until year 30. Averaged reservoir temperature during year 30 is $74.83^{\circ} \mathrm{C}$ (the average of initial temperature, $75.75^{\circ} \mathrm{C}$, and end-of-year 30 temperature, $73.91^{\circ} \mathrm{C}$ ). During the final weeks of year 30 , reservoir temperature falls slightly below $74^{\circ} \mathrm{C}$ in which case, however conservative, we require either re-drilling or use of the preheat option for all of year 30 . Re-drilling in year 30 would cost (in present value terms) some $\$ 2$ million, whereas benefits in year $30^{\dagger}$ are but $\$ 0.62$ million; obviously one would forgo benefits in year 30. Thus, lower costs shown for the HDR system without the preheat option ( $\$ 10.912$ million compared to $\$ 10.917$ million, upper part of Table XII) are associated with benefits for 29 years and net benefits (lower part of Table XII) are increased by using the preheat option in year 30 . Year 30 benefits are $\$ 0.62$ million and costs for the preheat option are but $\$ 0.005$ million, in present value terms. Therefore, notwithstanding slightly higher costs, net benefits for the preheat option ( $\$ 4.1$ million) exceed those for the 29-year, 4-fracture system without the preheat option ( $\$ 3.8$ million).

\footnotetext{
${ }^{*}$ This is accomplished by mixing return flows with HDR fluids; see IV.B.

** With these flow rates, the value of the relevant error functions for years 1 through 3 is but $1,0.99997$, and 0.9994, respectively.
}

the $\$ 879152$ fuel costs for the conventional systen, adjusted for $3 \%$ annual increases in oil costs and discounted at $7.25 \%$. 
TABLE XI

TIME PATH OF RESERVOIR TEMPERATURES AND WELL FLOW RATES FOR BASE CASE, FOUR FRACTURES

\begin{tabular}{|c|c|c|}
\hline Year & $\begin{array}{c}\text { Reservoir Temperature } \\
\text { at Beginning of Year } \\
\left({ }^{\circ} \mathrm{C}\right)\end{array}$ & $\begin{array}{l}\text { Well Flow Rate } \\
\text { During Year } \\
(\mathrm{kg} / \mathrm{sec}) \\
\end{array}$ \\
\hline 1 & 114.68 & 11.23 \\
\hline 2 & 114.68 & 11.23 \\
\hline 3 & 114.68 & 11.23 \\
\hline 4 & 114.65 & 11.24 \\
\hline 5 & 114.53 & 11.26 \\
\hline 6 & 114.27 & 11.32 \\
\hline 6 & 113.87 & 11.41 \\
\hline 8 & 113.28 & 11.54 \\
\hline 9 & 112.59 & 11.71 \\
\hline 10 & 111.73 & 11.91 \\
\hline$n$ & 110.75 & 12.16 \\
\hline 12 & 109.65 & 12.44 \\
\hline 13 & 108.43 & 12.77 \\
\hline 14 & 107.09 & 13.16 \\
\hline 15 & 105.63 & 13.61 \\
\hline 16 & 104.08 & 14.12 \\
\hline 17 & 102.43 & 14.71 \\
\hline 18 & 100.68 & 15.39 \\
\hline 19 & 98.83 & 16.18 \\
\hline 20 & 96.90 & 17.10 \\
\hline 21 & 94.89 & 18.18 \\
\hline 22 & 92.81 & 19.44 \\
\hline 23 & 90.68 & 20.93 \\
\hline 24 & 88.50 & 22.71 \\
\hline 25 & 86.30 & 24.85 \\
\hline 26 & 84.10 & 27.43 \\
\hline 27 & 81.92 & 30.57 \\
\hline 28 & 79.78 & 34.44 \\
\hline $\begin{array}{l}29 \\
30\end{array}$ & $\begin{array}{l}77.72 \\
75.75\end{array}$ & 39.23 \\
\hline (31) & $(73.91)^{a}$ & 52.36 \\
\hline
\end{tabular}

a Reservoir temperature at the end of year 30 .

The readers' appreciation for the nature of the optimal solution described above may be further enhanced by the following details.

(1) Deeper drilling, to $12699 \mathrm{ft}$, would result in higher initial temperature in the HDR reservoir. Costs associated with drilling the additional $1000 \mathrm{ft}$ ( $\$ 0.6 \mathrm{million})$ are not warranted, however, inasmuch as reservoir temperatures at $11699 \mathrm{ft}$ are sufficient to provide WFC energy requirements for 29 years. Drilling to $12699 \mathrm{ft}$ would provide all energy requirements for 30 years, but benefits in year 30 (\$0.262 million) are less than the associated costs. Thus, the minimum drilling depth of $11699 \mathrm{ft}$ is optimal. 
TABLE XII

PRESENT VALUE OF HDR SYSTEM COSTS AND NET BENEFITS

FOR ALTERNATIVE RESERVOIR DESIGNS: BASE CASE

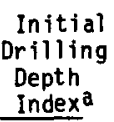

(106 1980 dollars)

Number of Fractures

\begin{tabular}{|c|c|c|c|c|c|c|c|c|c|c|c|c|c|c|}
\hline 1 & 36.1 & 14.9 & 18.4 & 12.4 & 13.6 & 11.4 & $10.912^{c}$ & 10.917 & 11.2 & 11.4 & 11.6 & 11.9 & 12.11 & 12.3 \\
\hline 2 & 32.7 & 15.2 & 17.3 & 12.6 & 13.8 & 11.6 & 11.6 & & & & & & & \\
\hline 3 & 25.2 & 15.2 & 15.1 & 12.7 & 12.1 & -- & & & & & & & & \\
\hline 4 & 25.9 & 15.4 & 19.5 & 16.1 & & & & & & & & & & \\
\hline 5 & 31.8 & 19.4 & 21.1 & 17.4 & & & & & & & & & & \\
\hline 6 & 28.6 & 19.8 & 21.7 & 18.0 & & & & & & & & & & \\
\hline 7 & 29.1 & 20.3 & 18.8 & -- & & & & & & & & & & \\
\hline 8 & 30.0 & 20.8 & & & & & & & & & & & & \\
\hline g & 27.1 & 22.0 & & & & & & & & & & & & \\
\hline
\end{tabular}

Net Benef its to HDR System (106 1980 dollars)

Number of Fractures

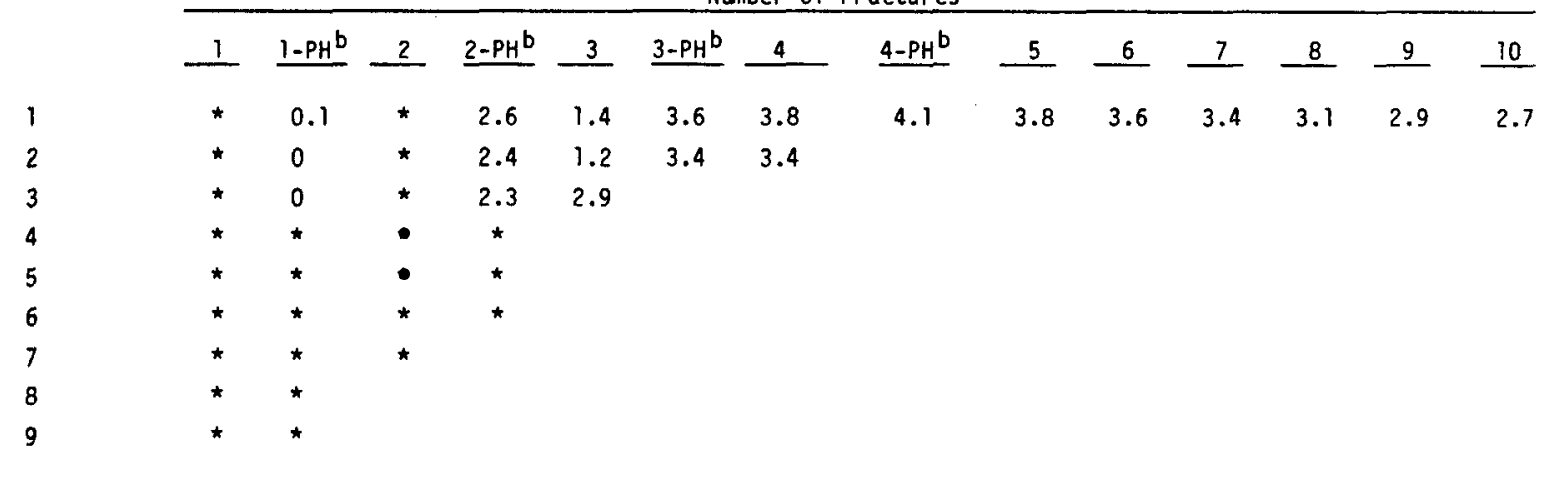

a See Table $x$.

bPH denotes preheat option.

$C_{A} 29$-year time horizon is used here. Gross benefits for 30 years, $\$ 15$ million, are reduced by $\$ 0.262$ million, which is the annual gross benefit in year 30 (\$879 152), inflated at $3 \%$ for rising oil prices and discounted at $7.25 \%$.

dGross benefits, $\$ 15$ million, less costs given in upper part of table.

*Denotes negative values. 
(2) If the reservoir was designed with only 3 fractures, reservoir temperature would fall below $74^{\circ} \mathrm{C}$ after 17 years with an initial drilling depth of $11587 \mathrm{ft}$. Re-drilling would add $\$ 2.8$ million to initial drilling costs of $\$ 8.5$ million; the use of the preheat option to meet design temperature requirements for the remaining 13 years would add $\$ 636000$ in present value costs (with real oil costs increased at $3 \%$ per year).* In both of these cases, system costs are higher than those for the 4-fracture system.

(3) Costs associated with designing the reservoir with 5 fractures--fracturing costs and costs for deeper drilling--are unwarranted inasmuch as the effect of the additional fracture (lower rates of temperature drawdown) is simply that of increasing the reservoir temperature at the end of year 30. In the absence of a terminal value function (see Sec. 3-E above), reservoir temperature in excess of $74^{\circ} \mathrm{C}$ at the end of the planning horizon of 30 years is not valued.

(4) Finally, the feasibility of the optimal--least cost--solution is obvious from data in Table XII. As noted above, the WFC's space heat requirements over 30 years is provided by the HDR system at a cost of $\$ 10.9$ million, $\$ 4.1$ million less than the $\$ 15$ million cost of providing space heat with the WFC's conventional steam system. Net cost savings--net benefits--attributable to an optimally designed HDR system are $\$ 4.1$ million. C. Minimum Reservoir Design

A question of some interest concerns minimum reservoir design requirements for an economically feasible HDR system. What is the minimum number of fractures for an HDR reservoir used to provide the WFC's space heating needs whereby HDR system costs would still be less than those for the conventional steam system? A response to this question is obtained from data in Table XIII. The HDR system is marginally feasible with one fracture and the use of the preheat option. "HDR costs in this case are $\$ 74.9$ million compared with $\$ 15$ million costs for the WFC's steam system.

In this 1-fracture, preheat option case, temperature drawdown with the small reservoir surface area provided by one fracture is quite high and

*In comparing costs for 3 and 3-preheat fractures with 4 fractures in Table XII, the reader must recall that initial drilling depth is less, and therefore costs are lower, for 3 fractures $(11556 \mathrm{ft})$ than for 4 fractures (11 $699 \mathrm{ft}$ ) (see Table X). 
reservoir temperature falls below the design temperature of $74^{\circ} \mathrm{C}$ after only 4 years (see column 3 of Table XIII). The justification for spending $\$ 7.77$ million in drilling costs to establish an HDR reservoir that fully satisfies the RFC's heating requirements for only four years* may not be immediately obvious to the reader, in which case a detailed analysis of this system may be useful.

Consider data in Table XIII. Initial drilling is to $11273 \mathrm{ft}$ and

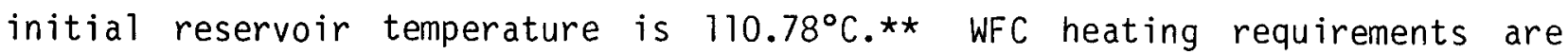
fully satisfied during years 1 through 3 ; benefits to the HOR system during years 1 through 3 are the full value of avoided costs from the conventional, steam system. In year 4, however, average HDR reservoir temperature during the second half of the year is $71.7^{\circ} \mathrm{C}$. $^{\dagger}$

Using the relationship:

$$
\begin{aligned}
\text { Btu/second } & =\frac{\text { flow rate }(\mathrm{m}) \times 4200 \times\left(74^{\circ}-71.7^{\circ} \mathrm{C}\right)}{1054}(1.27),{ }^{+\dagger} \\
\text { Btu/year } & =31.536 \times 10^{6} \frac{(52.36 \mathrm{~kg} / \mathrm{sec}) \times(9660)}{1054}(1.27), \\
& =19.22 \times 10^{9},
\end{aligned}
$$

the $2.3^{\circ} \mathrm{C}$ by which design temperature exceeds reservoir temperature translates into an annual Btu deficit of 19.22 billion. Because the deficit only applies to half a year in year 4 , the deficit is $9.6 \times 10^{9}$ Btu (Table XIII). Assuming 6.048 million Btu per barrel of No. $60 i 1$ (144000 Btu/gal),

*Actually, full requirements are met for only $31 / 2$ years; see discussion below.

${ }^{*} 90^{\circ} \mathrm{C}$ at basement $(9000 \mathrm{ft}) ; 30^{\circ} \mathrm{C} / \mathrm{km}$ for remaining $2273 \mathrm{ft}(0.6928 \mathrm{~km})$; $20.78^{\circ} \mathrm{C}$.

The average temperature at the beginning of year $4\left(79.93^{\circ} \mathrm{C}\right)$ and at the end of year 4 (beginning of year $5,68.96^{\circ} \mathrm{C}$ ) is $74.4^{\circ} \mathrm{C}$; average temperature during the second half of the year is the average of $74.4^{\circ} \mathrm{C}$ and $68.96^{\circ} \mathrm{C}$, or $71.7^{\circ} \mathrm{C}$.

t†The factor 1.27 inflates required Btus for boiler and feed water losses. Distribution losses (5\%) for the hot water system are included in the flow rate of $52.36 \mathrm{~kg} / \mathrm{sec}$. 
TABLE XIII

PERF ORMANCE OF THE HDR SYSTEM WITH I FRACTURE AND PREHEAT OPTION: BASE CASE
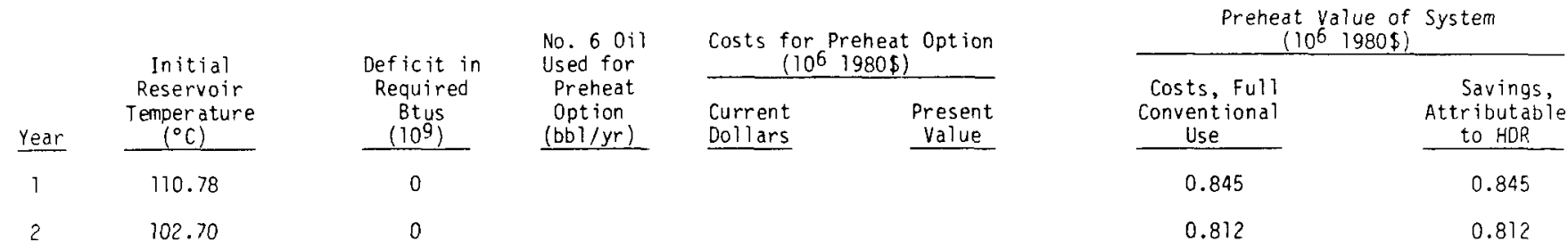

390.73

$4 \quad 79.93$

0

9.6

1585

0.056

0.045

0.812

0.812

0.779

0.779

44.7

7399

0.274

0.208

0.748

0.703

49.4

8164

0.313

0.221

0.719

0.511

52.9

8742

0.344

0.227

0.690

0.469

55.6

9200

0.373

0.664

0.437

57.9

9574

0.401

0.229

0.637

0.408

59.8

9886

0.229

0.612

0.383

61.4

10153

0.426

0.227

0.587

0.360 .

62.8

10384

0.451

0.224

0.564

0.340

64.0

10587

0.474

0.219

0.542

0.322

65.1

10767

0.498

0.215

0.527

0.305

66.1

10928

0.210

0.499

0.289

676.0

11072

0.546

0.205

0.480

0.275

67.8

11204

0.569

0.199

0.461

0.262

68.5

11324

0.594

0.194

0.443

0.249

69.2

0.618

0.188

0.425

0.237

69.8

11434

0.642

0.182

0.408

0.225

65.69

65.61

11536

0.667

0.177

0.392

0.215

70.3

11630

0.693

0.171

0.376

0.205

70.9

11718

0.720

0.165

0.361

0.196

71.4

0.746

0.160

0.348

0.188

71.8

11876

0.774

0.155

0.334

0.179

72.3

11947

0.801

0.150

0.320

0.170

72.7

12015

0.744

0.307

0.163

73.0

12078

0.859

0.139

0.296

0.157

73.4

$12 \quad 138$

0.889

0.735

0.284

0.149

73.8

12195

0.921

0.129

0.272

0.143

74.1

12249

0.953

0.125

0.262

0.137

65.12

TOTALS

4.872

15.0

10.12

NOTE: Drilling costs $(\$ 7.77$ million) pius $\$ 2.25$ million for pipes and heat exchangers $=\$ 10.02$ million. 
approximately 1585 barrels of $0 i 1$ are required to raise the HDR fluid (at $52.36 \mathrm{~kg} / \mathrm{sec}$ ) from $71.7^{\circ} \mathrm{C}$ to $74^{\circ} \mathrm{C}$. At the beginning of year 4 , the $0 i 1$ costs $/ \mathrm{bb} 1$ is $\$ 35.01$ ( $\$ 33.00$ compounded at $3 \%$ per year), in which case preheat costs are $\$ 56000$ (rounded), or $\$ 45000$ in present value terms (using a discount rate of $7.25 \%$ ). Fuel costs in year 4 for the HDR system of $\$ 45000$ must then be subtracted from fuel costs that would be incurred with the WFC's steam system ( $\$ 48000$ present value) to determine savings--benefits--in year 4 attributable to the HDR system $(\$ 703000)$. Repeating this procedure through year 30 , total costs for the HDR system are: $\$ 7.7$ million for drilling costs plus $\$ 2.25$ million pipe/heat exchanger costs in year 1 plus $\$ 4.872$ million, the present value of fuel costs for raising preheated HDR fluids to $74^{\circ} \mathrm{C}$ or $\$ 14.9$ million. Costs for the WFC's steam system are $\$ 15$ million; the net benefits-net cost savings--attributable to the HDR system are thus $\$ 0.1$ million.*

Still another manner for gaining insight as to the value of the HDR system in providing preheated water for the WFC's space heat needs is the following. Ignoring differentials in system heat losses, it was demonstrated in Sec. II.B that roughly 1400 barrels of No. 6 oil--some $\$ 46460$, 1980 dollars--are required to increase water temperature by $1^{\circ} \mathrm{C}$. Without preheated water, water temperature must be raised by an amount equal to the system's temperature drop (the WT), or $11.11^{\circ} \mathrm{C}$. The HDR system provides $52.36 \mathrm{~kg} / \mathrm{sec}$ at $68.6^{\circ} \mathrm{C}, 68.1^{\circ} \mathrm{C}, 67.7^{\circ} \mathrm{C}$, and $67.3^{\circ} \mathrm{C}$ in (for example) years $5,6,7$, and 8 , respectively. During those four years, make-up temperature with $\mathrm{HDR}$ preheated water is $5.4^{\circ} \mathrm{C}, 5.9^{\circ} \mathrm{C}, 6.3^{\circ} \mathrm{C}$, and $6.7^{\circ} \mathrm{C}$, respectively, in comparison with $11.11^{\circ} \mathrm{C}$ for the conventional system. Therefore, for this example, annual fuel costs in each of the 4 years would be some $\$ 517000$ with the WFC's steam system** wherein water temperature is raised by $11.11^{\circ} \mathrm{C}$, whereas respective annual fuel costs with HDR preheated water are $\$ 252000, \$ 276000, \$ 294000$, and $\$ 313000$. Corresponding annual savings in fuel costs--benefits

*of course, this is equivalent to the present value of annual fuel cost savings ( $\$ 10.12$ million) net of $d r i l l i n g$ and pipe costs (\$10.02 million).

** To avoid confusion in comparing this $\$ 517000$ figure with costs given in Table XIII, the reader must recall the substantial losses associated with the WFC system: $27 \%$ boiler/feed water losses and $30 \%$ distribution line losses. 
attributable to the HDR system--are $\$ 265000, \$ 242000, \$ 224000$, and $\$ 205000$. The important point suggested by this example is

That while HDR preheated water may reduce (from $11.11^{\circ} \mathrm{C}$ ) required temperature increases by what may seem to be small amounts $\left(4^{\circ} \mathrm{C}\right.$, $5^{\circ} \mathrm{C}$, etc.), small temperature differences translate into large cost savings $\left(46640\right.$-plus per $\left.1^{\circ} \mathrm{C}\right)$. Herein lies a large potential value for HDR resources in space heat applications.

\section{Minimum Reservoir Design: Without the Preheat Option}

For completeness, we wish to briefly consider a minimum reservoir design in the case where the preheat option is not used. Interest in this possibility could arise with conditions of extreme scarcity of oil reserves wherein oil conservation is given high priorities in system design.

Referring to data in Table XII, the minimum reservoir design--number of fractures--wherein HDR system costs remain below costs for the WFC's steam system (that is, net benefits remain positive) is the design with 3 fractures. With 3 fractures, HDR system costs are $\$ 12.1$ million compared with $\$ 15$ million for the conventional system; net benefits that obtain with 3 fractures (excluding the preheat option) are $\$ 2.9$ million using a 30 -year planning horizon.

Underlying the minimum reservoir design, 3-fracture program, initial drilling depth is to $13557 \mathrm{ft}$; initial reservoir temperature is $131.6^{\circ} \mathrm{C}$. The high (relative to design temperature of $74^{\circ} \mathrm{C}$ ) initial reservoir temperature permits the use of relatively small well flow rates (the well flow rate in year 1 is but $8.62 \mathrm{~kg} / \mathrm{sec}$ ), * thereby reducing the rate of temperature drawdown (notwithstanding the smaller reservoir surface area provided by 3 fractures). Pre-drilling is, therefore, not required.

\section{E. Summary}

The following summarizes the results of our analysis of the implications of using HDR geothermal resources for space heating purposes at the WFC under base case assumptions.

An optimal design for the HDR system requires a reservoir design with four fractures and the use of the preheat option. The 4fracture system is feasible--costs for the HDR system are $\$ 4.1$ million less than costs for the WFC'S oil-using steam system. 
An HDR reservoir with one fracture can be economically feasible with the preheat option. With one fracture, HDR system costs, including oil costs for make-up temperatures, are $\$ 0.1$ million less than costs for the WFC'S oil-using steam system.

Without the preheat option, minimum reservoir design requires three fractures. With this system, HDR costs are $\$ 2.9$ million less than costs for the WFC's oil-using system.

\section{SENSITIVITY ANALYSES}

A. Sensitivity Analyses for Economic Parameters

Our analyses of economic parameters begin with an examination of the sensitivity of net benefits to the HDR system as alternative discount rates are used; relevant data are given in Table XIV.

of course, net benefits are affected by discount rates in two ways. First, gross benefits are discounted (present value) costs of oil used at the WFC main steam $\mathrm{plant}$ over 30 years--the larger the discount rate, the smaller are gross benefits (see footnote $d$ in Table XIV). Second, HDR system costs other than initial costs--redrilling costs and fuel costs for the preheat option--are discounted to the beginning of year 1; larger discount rates imply smaller present values for these costs.

In terms of the feasibility of HDR space heat applications, the importance of discount rates centers on one primary consideration: reservoir design. As shown in Table XIV, with 3 (or more) fractures an optimal solution will require drilling to a depth* such that initial reservoir temperatures are sufficiently high to satisfy all energy requirements over the planning horizon. Thus, future costs are not incurred and system costs are independent of the discount rate--discounting affects on $1 y$ gross benefits.

As shown in Table XIV, with $4 \%$ and $71 / 4 \%$ discount rates, the HDR system is feasible with 1 or 2 fractures with the preheat option; the 2-fracture case is feasible with re-drilling at the $4 \%$ discount rate. In no case is the HDR system feasible with the higher, $10 \%$, real rate of discount; this result is somewhat obvious given that net benefits fall by $26 \%-$-from $\$ 15$ million to $\$ 11.1$ million (Table I)--as the discount rate rises from $71 / 4 \%$ to $10 \%$. From

${ }^{\star}$ For this case study, $13557 \mathrm{ft}$. 
TABLE XIV

FEASIBILITY MEASURES FOR THE HDR SYSTEM WITH ALTERNATIVE DISCOUNT RATES

Reservoir Design:

Number of

Fractures

1

2

3

$12.1^{\mathrm{C}}$

Base Case
$71 / 4 \%$

Without $\mathrm{PH}$ With $\mathrm{PH}$

14.9

12.7

$-$

Total costs

$\left(10^{6}\right.$ 1980\$)

$5.1^{\mathrm{b}}$

-
32.9
17.1

$4 \%$

$10 \%$

\begin{tabular}{lc} 
Without PH & With PH \\
\hline $21.3^{\mathrm{a}}$ & 13.9 \\
$14.0^{\mathrm{b}}$ & 12.4 \\
$12.1^{\mathrm{C}}$ & --
\end{tabular}

Net Benef its d

$\left(10^{6}\right.$ 1980\$)

Reservoir Design:

Number of

Fractures

1
2
3

\begin{tabular}{cc}
\multicolumn{2}{c}{ Base Case } \\
$71 / 4 \%$ \\
\hline Without PH & With PH \\
\hline-10.2 & 0.1 \\
-0.1 & 2.3 \\
2.9 & --
\end{tabular}

anitial depth, $13273 \mathrm{ft}$.

bInitial depth, $13415 \mathrm{ft}$.

CInitial depth, $13557 \mathrm{ft}$.

${ }^{d}$ Gross benefits with discount rate $=71 / 4 \%$ are $\$ 15 \mathrm{million}$; for rate $=4 \%, \$ 22.8 \mathrm{million}$; and for rate $=10 \%$, \$11.1 million (see Table 1). 
these observations we conclude that, all else equal, feasibililty of the HDk space heat application of interest here obtains at real, inflation-free, discount rates below $10 \%$.

Data concerning the sensitivity of net benefits to alternative annual rates of change in real oil costs and real drilling costs are given in Tables XV and XVI. To capture the full impact of alternative rates of increase in real oil costs, attention is focused on reservoir designs with the preheat option wherein future oil costs are included in HDR system costs. In examining drilling costs, however, we consider cases where re-drilling (rather than preheat) options are used; otherwise, of course, increased drilling costs would be irrelevant.

Referring to data in Table XV, note that, all else equal, the feasibililty of the HDR space heating application is independent of the annual rate of increase in oil prices for the range of increases considered here. It must be noted, however, that this conclusion is relevant only for the HDR design strategy wherein the preheat option is used. When re-drilling takes place, increases in $0 i 1$ prices (which affect gross benefits) relative to increases in drilling costs become an important consideration; the relative price issue--oil costs relative to drilling costs--is discussed below.

The sensitivity of net benefits to alternative annual rates of increase in drilling costs is demonstrated in Table XVI. For reservoir designs involving 3 or more fractures, the HDR space heat application is shown to be feasible for all rates of increase in drilling costs between 3\%/year and $6 \% /$ year (with oil costs increasing at the base case 3\% per year).

It is desirable to extend the above discussion concerning increases in oil costs and drilling costs to include alternative combinations of these values. This follows from two considerations. First, oil prices and drilling costs are interrelated (see Sec. III above); thus, rapid increases in oil prices may be associated with rapid increases in drilling costs--this has certainly been the case in the post-1973 period. Second, the feasibility of HDR space heat applications under alternative relative prices is, itself, of interest in evaluating the commercial potential of HDR resources.

Data in Table XVII relate to the first issue described above. The HDR system is shown to be feasible--net benefits are positive--under high ( $4 \%$ to $6 \%$ ) and low (2\% to $3 \%$ ) scenarios for increases in real drilling and oil costs. One particularly interesting point is brought out by these data: 


\begin{tabular}{|c|c|c|c|}
\hline \multirow[b]{2}{*}{$\begin{array}{c}\text { No. of } \\
\text { Fractures }\end{array}$} & \multicolumn{3}{|c|}{$\begin{array}{l}\text { Total Costs } \\
\left(10^{6} 1980 \$\right)\end{array}$} \\
\hline & $\begin{array}{c}\text { Base Case } \\
3 \% \\
\end{array}$ & $2 \%$ & $4 \%$ \\
\hline 1 & 14.7 & 14.0 & 15.4 \\
\hline 2 & 12.4 & 12.0 & 12.8 \\
\hline & & $\begin{array}{r}\text { Bene } \\
61980 \\
\end{array}$ & \\
\hline $\begin{array}{l}\text { No. of } \\
\text { Fractures } \\
\end{array}$ & $\begin{array}{c}\text { Base Case } \\
3 \% \\
\end{array}$ & $2 \%$ & $4 \%$ \\
\hline 1 & 0.3 & -0.7 & 1.6 \\
\hline 2 & 2.6 & 1.3 & 4.2 \\
\hline
\end{tabular}

agross benefits are $\$ 15$ million for a $3 \%$ rate, $\$ 13.3$ for a $2 \%$ rate and $\$ 17.0$ for a $4 \%$ rate (Table I).

effects on gross benefits from increases in real oil prices dominate effects on re-drilling costs from increases in drilling costs. Thus, when annual rates of increase are doubled for both the $0 i 1$ prices and the drilling costs ( $2 \%$ to $4 \%$ and $3 \%$ to $6 \%$, respectively), gross benefits increase by $28 \%$ compared to a $12 \%$ increase in total drilling costs and net benefits increase by over $700 \%$ (from $\$ 0.3$ million to $\$ 2.5$ million).

In terms of relative prices, we can define the relative increase in drilling cost--relative to oil prices--as the ratio of the rate of increase in drilling costs to the rate of increase in drilling costs--denoted $x$ for simplicity--was $4.34 \% \div 3 \%$, or $x=1.45$; that is, in the base case, drilling costs were assumed to increase each year by $45 \%$ more than were $0 i 1$ prices. According to data in Table XVIII, very high values for $x$ (real drilling costs increase at three times the rate of real oil prices) result in negative net benefits. At lower values of $x$, of course, net benefits increase substantialiy and the HOR system is feasible (Table XVIII).

The final parameters of interest in this section are contingency factors. Contingency factors affect all costs associated with time required for drilling; costs related to rig-time constitute about $65 \%$ of total drilling costs. Contingency factors of $50 \%$ and $15 \%$ for drilling in permeable and 
SYSTEM COSTS AND NET BENEF ITS FOR THE HDR SYSTEM, WITHOUT PREHEAT OPTION, FOR ALTERNATIVE INCREASES IN REAL DRILLING COSTS

\begin{tabular}{|c|c|c|c|}
\hline \multirow[b]{2}{*}{$\begin{array}{l}\text { No. of } \\
\text { Fractures } \\
\end{array}$} & \multicolumn{3}{|c|}{$\begin{array}{l}\text { Total Costs } \\
(1061980 \$)\end{array}$} \\
\hline & $\begin{array}{c}\text { Base Case } \\
4.34 \% \\
\end{array}$ & $3 \%$ & $6 \%$ \\
\hline $2^{a}$ & 15.1 & 14.5 & 16.0 \\
\hline $3^{b}$ & 13.6 & 13.0 & 14.5 \\
\hline \multirow[t]{2}{*}{$4 C$} & 13.0 & 12.4 & 14.2 \\
\hline & \multicolumn{3}{|c|}{$\begin{array}{l}\text { Net Benefits } \\
\left(10^{d} 1980 \$\right)\end{array}$} \\
\hline $\begin{array}{c}\text { No. of } \\
\text { Fractures }\end{array}$ & $\begin{array}{c}\text { Base Case } \\
4.34 \% \\
\end{array}$ & $3 \%$ & $6 \%$ \\
\hline 2 & -0.1 & 0.5 & -1.0 \\
\hline 3 & 1.4 & 2.0 & 0.5 \\
\hline 4 & 2.0 & 2.6 & 0.8 \\
\hline
\end{tabular}

Initial drilling depth is $13415 \mathrm{ft}$.

bInitial drilling depth is $11557 \mathrm{ft}$.

CInitial driling depth is $11699 \mathrm{ft}$.

dGross benefits are $\$ 15$ million for al1 cases.

impermeable material, respectively, are used in the base case. Net benefits are given in Table XIX for cases where contingency factors of $50 \% / 50 \%$ and $100 \% / 100 \%$ are used. From these data, note that the HDR system remains feasible with the 50\%/50\% contingency factors and is only marginally infeasible with contingency factors of $100 \%$.

B. Sensitivity Analyses for Design Parameters

Three sets of design parameters are of concern in this section: system scale (Btu requirements), temperature drawdown, and site characteristics (depth to basement and geothermal temperature gradient). Data concerning Btu requirements are given in Table $X X$. Of particular interest for the commercial potential of HDR space heat applications is the behavior of benefits and costs that attend changes in scale. In Table $X X$, at a scale where annual energy requirements are $36.4 \times 10^{9}$ Btus, HDR system costs are higher than benefits (costs of providing these Btus with the WFC's conventional steam system). For 
TABLE XVII

BENEFITS AND COSTS TO THE HDR SYSTEM WITH ALTERNATIVE COMBINATIONS

FOR INCREASES IN REAL OIL PRICES AND REAL DRILLING COSTS: 3-FRACTURE DESIGN WITH RE-DRILLING

\begin{tabular}{|c|c|c|c|c|c|c|}
\hline \multirow[b]{3}{*}{ Base case } & \multicolumn{3}{|c|}{$\begin{array}{c}\text { Annual Increase } \\
(\not{x})\end{array}$} & \multicolumn{3}{|c|}{$\begin{array}{l}\text { HDR System } \\
\left(10^{6} \quad 1980 \$\right)\end{array}$} \\
\hline & $\begin{array}{r}\text { Real } \\
0 i 1 \\
\text { Prices } \\
\end{array}$ & with & $\begin{array}{c}\text { Real } \\
\text { Drilling } \\
\text { Costs } \\
\end{array}$ & $\begin{array}{c}\text { Gross } \\
\text { Benef itsa } \\
\end{array}$ & Costs & $\begin{array}{c}\text { Net } \\
\text { Benefits } \\
\end{array}$ \\
\hline & 3 & & 4.34 & 15.0 & 13.6 & 1.4 \\
\hline \multirow[t]{3}{*}{ Comparisons } & 2 & & 3 & 13.3 & 13.0 & 0.3 \\
\hline & 4 & & 6 & 17.0 & 14.5 & 2.5 \\
\hline & 3 & & 3 & 15.0 & 13.0 & 2.0 \\
\hline
\end{tabular}

NOTE: Re-drilling is in year 18.

a See Table I.

TABLE XVIII

NET BENEF ITS TO THE HDR SPACE HEAT APPLICATION WITH ALTERNATIVE RELATIVE (TO OIL) INCREASES IN ORILLING COSTS

\begin{tabular}{|c|c|c|c|c|}
\hline \multirow{2}{*}{\multicolumn{2}{|c|}{$\begin{array}{c}\text { Relative } \\
\text { Annual } \\
\text { Rate of } \\
\text { Increase, } \\
\text { Drilling Costs } \\
\end{array}$}} & \multicolumn{3}{|c|}{$\begin{array}{l}\text { HDR System } \\
\left(10^{6} 1980 \$\right)\end{array}$} \\
\hline & & $\begin{array}{c}\text { Gross } \\
\text { Benef its } \\
\end{array}$ & $\operatorname{Costs}^{a}$ & $\begin{array}{c}\text { Net } \\
\text { Benefits }\end{array}$ \\
\hline \multirow[t]{3}{*}{ Base case } & 1.45 & 15.0 & 13.6 & 1.4 \\
\hline & $3.0^{b}$ & 13.3 & 14.5 & -1.2 \\
\hline & $0.75^{C}$ & 17.0 & 13.0 & 4.0 \\
\hline
\end{tabular}

aThese data apply to the 3 -fracture reservoir design; initial drilling is to $557 \mathrm{ft}$. Re-drilling takes place in year 18.

$b_{6 \%}$ annual rate of increase in real drilling costs, $2 \%$ for $0 i 1$ prices.

C3\% annual rate of increase in real drilling costs, $4 \%$ for oil prices. 
TABLE XIX

BENEF ITS AND COSTS FOR HDR SYSTEM WITH ALTERNATIVE CONTINGENCY FACTORS:

RESERVOIR DESIGN WITH 4 FRACTURES

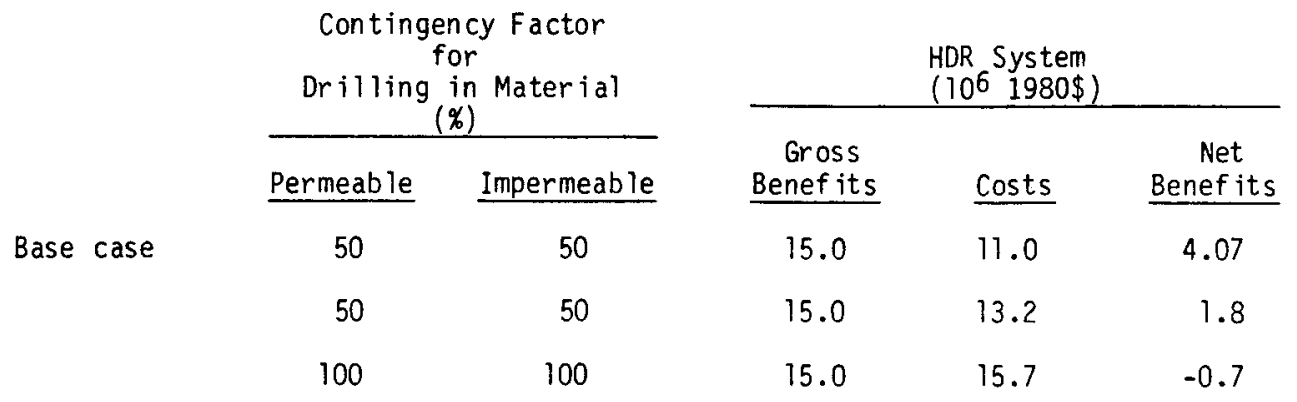

this scale, cost minimization requires 2 fractures and use of the preheat option in year 28. When the scale is doubled to the base case scale of $72.8 \times 10^{9}$ Btus, benefits double but costs increase by some $6 \%$; 4 fractures are required with the preheat option used in year 30 . With scale increased by an additional 50\%--to $109.2 \times 10^{9}$ Btu--benefits increase proportionately (by $50 \%)$ but costs increase by only 5\%. For this larger scale, note that 6 fractures are required and neither preheat nor re-drilling activities are used.

A more meaningful comparison can be made between the larger system scales by fixing the number of fractures at the base case level of 4 ( $B$ of Table $X X$ ). With the 4-fracture system, an increase in scale by $50 \%$ over the base case level (to $109.227 \times 10^{9}$ Btu) results in a cost increase of $28 \%$. Still, however, the conclusion remains that, over some $r$ ange, ${ }^{*}$ scale increases result in proportional increases in benefits and less than proportional increases in sys tem costs.

As discussed above in Sec. IV, precise estimates for temperature drawdown in HDR reservoirs must await more experience with the continual use of reservoirs for space heat and/or other uses. Best available estimates for the relationship between reservoir use and temperature drawdown are based on theoretical models (see App. D) and few data exist for verification purposes. Given the critical importance of temperature drawdown for assessments of the feasibility of HDR applications, and the lack of alternative methods for estimating drawdown relationships, temperature drawdown rates used above in

*An interesting question then concerns an optimal scale. Unfortunately, this issue extends well beyond the intended scope of this research report. 
TABLE $X X$

BENEFITS AND COSTS FOR HDR SYSTEM WITH ALTERNATIVE BtU REQUIREMENTS

\begin{tabular}{|c|c|c|c|c|c|c|c|}
\hline \multirow[b]{3}{*}{ Case } & \multirow{3}{*}{$\begin{array}{c}\text { Heat } \\
\text { Needed } \\
\left(10^{9} \text { Btu }\right) \\
\end{array}$} & \multirow{2}{*}{\multicolumn{3}{|c|}{$\begin{array}{r}\text { HDR System } \\
\left(10^{6} \quad 1980 \$\right) \\
\end{array}$}} & \multicolumn{3}{|c|}{$\begin{array}{l}\text { System Characteristics } \\
\text { with Optimal Solution }\end{array}$} \\
\hline & & & & & \multirow[b]{2}{*}{$\begin{array}{l}\text { No. of } \\
\text { Fractures }\end{array}$} & \multirow[b]{2}{*}{$\begin{array}{c}\text { Re-Dri } 1 \text { ling } \\
(y r)\end{array}$} & \multirow{2}{*}{$\begin{array}{c}\text { Preheat 0ptior } \\
\text { Used } \\
\text { (beginning yr) }\end{array}$} \\
\hline & & $\begin{array}{c}\text { Gross } \\
\text { Benefits } \\
\end{array}$ & Costs & $\begin{array}{c}\text { Net } \\
\text { Benefits } \\
\end{array}$ & & & \\
\hline \multirow[t]{2}{*}{ A } & 36.409 & 7.5 & 10.3 & -2.8 & 2 & -- & 28 \\
\hline & 109.227 & 22.5 & 11.4 & 11.1 & 6 & No & No \\
\hline Base & 72.818 & 15.0 & 10.9 & 4.1 & 4 & No & 30 \\
\hline B & 109.227 & 22.5 & 14.0 & 8.5 & 4 & 16 & -- \\
\hline
\end{tabular}

base case analyses are doubled in our efforts to analyze the impact of temperature drawdown on the commercial potential of HDR resources used for space heat applications.

Benefits and costs for the HDR space heat application at the WFC are given in Table XXI for the case where base case temperature drawdown rates are doubled. Base case data are given in parentheses to facilitate comparisons. As one might expect with higher drawdown rates, the optimal--least cost-solution requires a much larger surface area for the HDR reservoirs: 7 fractures compared to 4 fractures in the base case. With the 7-fracture reservoir design, temperatures established by initial drilling are sufficient to satisfy the WFC's energy requirements (for space heat) during the entire 30-year planning horizon--that is, neither the re-drilling nor the preheat option is used.

Minimum reservoir design requirements with doubled temperature drawdown rates involve 4 fractures with the preheat option initiated in year 17; this compares with 1 fracture in the base case wherein the preheat option is in itiated in year 4 .

Finally, data concerning the sensitivity of net benefits to the HDR space heat application to site characteristics are given in Table XXII. In considering these data, the reader is advised that meaningful comparisons of effects from differing gradients can be drawn from these data for a given depth to basement; one cannot compare costs (or net benefits) for a given gradient across depth to basement levels, however. This limitation is due to the fact that different drilling programs are used in the RGI code (App. B) 
TABLE XXI

BENEF ITS AND COSTS FOR HDR SYSTEM WITH TEMPERATURE DRAWDOWN INCREASED BY $100 \%$

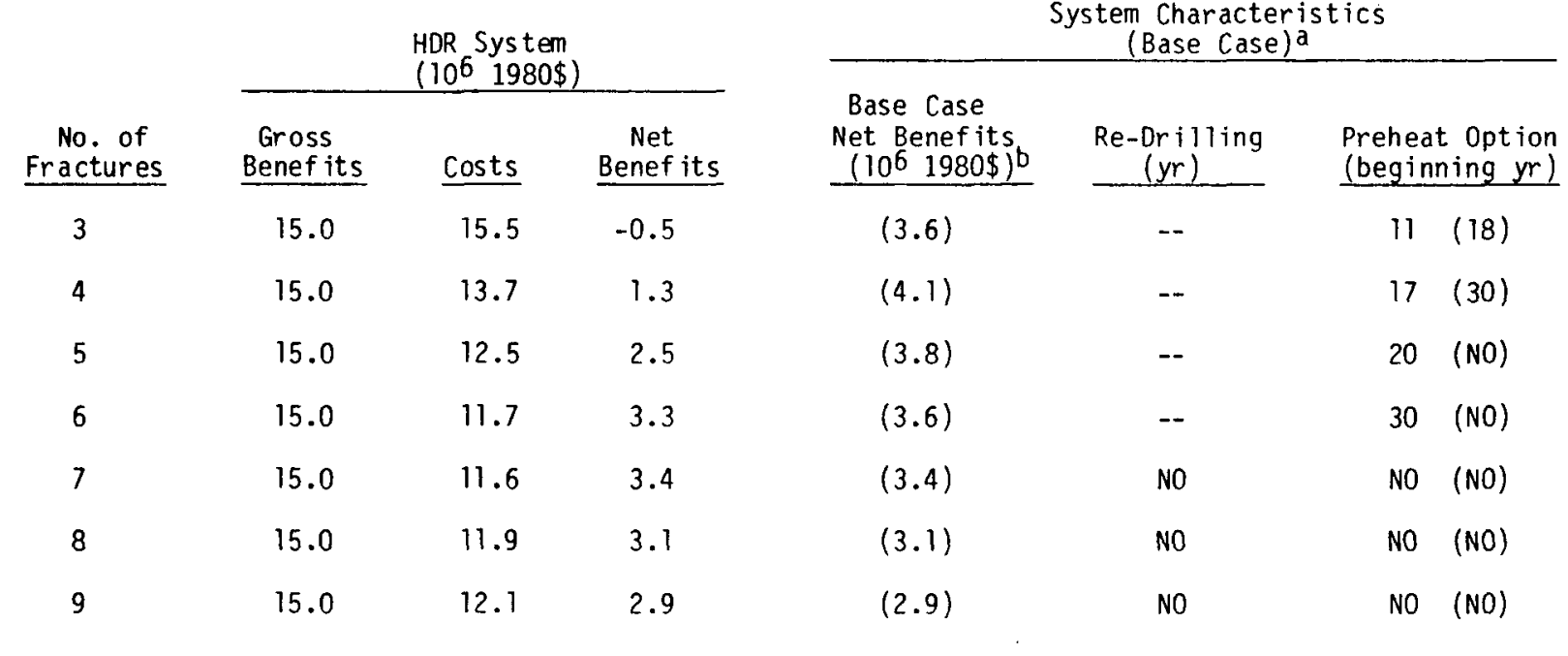

abase case, in parentheses.

bTable XII.

for different depth to basement levels. For example, with depth to basement of $9000 \mathrm{ft}$, the RGI casing program for the producer well uses 17.5-in diameter casing for $1840 \mathrm{ft}, 12.3-$ in casing for $9000 \mathrm{ft}$; with depth to basement of $5700 \mathrm{ft}, 17.5$-in casing is used for the entire $5700 \mathrm{ft}$ in the relevant casing program.

With the large, $9000 \mathrm{ft}$ depth to basement, drilling is always to minimum depths for 4 fractures--11 $699 \mathrm{ft}$; thus, as one would expect, varying gradients have little effect on system benefits. The $25^{\circ} \mathrm{C}$ gradient increases costs through the necessity of beginning the preheat option in year 12, rather than in year 30 as in the base case. Higher (than the base case, $30^{\circ} \mathrm{C} / \mathrm{km}$ ) gradients simply remove the necessity of using the preheat option in year 30 .

With lower depths to basement, the effects of higher gradients are immediately apparent. With depth to basement of 5700 and $2400 \mathrm{ft}$, net benefits increase by $56 \%$ to $100 \%$ as the gradient increases from $25^{\circ} \mathrm{C} / \mathrm{km}$ to $40^{\circ} \mathrm{C} / \mathrm{km}$. All of this is to suggest the increase in net benefits to HDR space heat applications in areas with higher geothermal gradients than those found in the WFC case study area. 
TABLE XXII

BENEF ITS AND COSTS FOR HDR SYSTEM WITH ALTERNATIVE SITE CHARACTERISTICS: DEPTH TO BASEMENT AND GEOTHERMAL GRADIENT

\begin{tabular}{|c|c|}
\hline $\begin{array}{l}\text { Depth to } \\
\text { Basement } \\
\text { (ft) }\end{array}$ & $\begin{array}{c}\text { Geothermal } \\
\text { Temper ature } \\
\text { Gradient } \\
\left({ }^{\circ} \mathrm{C} / \mathrm{km}\right) \\
\end{array}$ \\
\hline 9000 & 25 \\
\hline 9000 & 30 \\
\hline 9000 & 35 \\
\hline 9000 & 40 \\
\hline 5700 & 25 \\
\hline 5700 & 30 \\
\hline 5700 & 35 \\
\hline 5700 & 40 \\
\hline 2400 & 25 \\
\hline 2400 & 30 \\
\hline 2400 & 35 \\
\hline 2400 & 40 \\
\hline
\end{tabular}

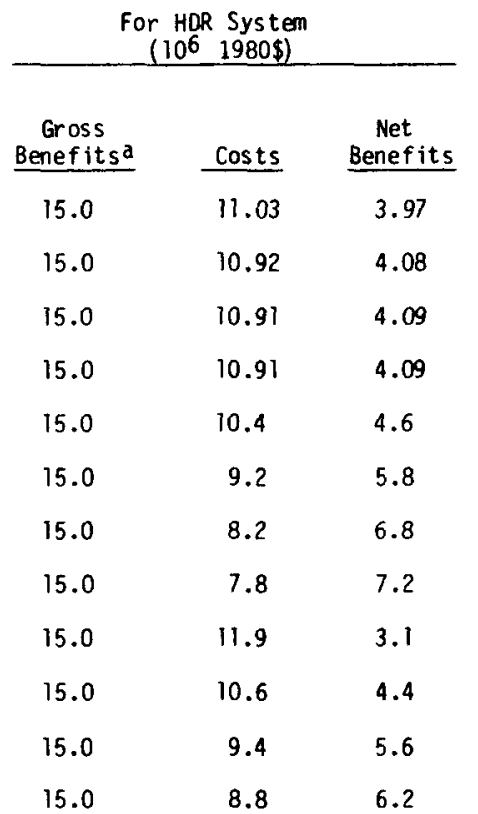

\begin{tabular}{|c|c|c|c|}
\hline $\begin{array}{l}\text { Initial } \\
\text { Driliing } \\
\text { Depth } \\
(\mathrm{ft}) \\
\end{array}$ & $\begin{array}{l}\text { No. of } \\
\text { Fractures }\end{array}$ & $\begin{array}{l}\text { Re-Drilling } \\
(y r)\end{array}$ & $\begin{array}{c}\text { Preheat } \\
\text { Option } \\
\text { (beginning } y r)\end{array}$ \\
\hline 1) 699 & 4 & -- & 26 \\
\hline 11699 & 4 & -- & 30 \\
\hline 11699 & 4 & NO & NO \\
\hline 11699 & 4 & NO & NO \\
\hline 10399 & 4 & - & 12 \\
\hline 9399 & 4 & -- & 17 \\
\hline 8399 & 4 & -- & 20 \\
\hline 8399 & 4 & NO & NO \\
\hline 10099 & 4 & -- & 10 \\
\hline 10099 & 4 & -- & 23 \\
\hline 8099 & 4 & -- & 18 \\
\hline 8099 & 4 & - & 18 \\
\hline
\end{tabular}

a See Table I.

VII. CONCLUSIONS

In drawing conclusions from this work concerning the feasibility of space heat applications for hot, dry rock geothermal resources, it is useful to begin by reviewing the more critical basic assumptions underlying the analyses. First, initial drilling costs are based on estimates from the RGI study of drilling costs (App. B). For drilling depths in the range $11200 \mathrm{ft}$ to $13400 \mathrm{ft}$, these costs range from $\$ 10$ million to $\$ 17$ million for 1 fracture, $9000 \mathrm{ft}$ to basement and base case assumptions; for drilling to $15000 \mathrm{ft}$, RGI drilling costs are in the $\$ 13 \mathrm{million}$ to $\$ 21$ million range.* These costs, for $15000 \mathrm{ft}$, are in the range of actual drilling costs to these depths (roughiy) incurred in the Lab's HDR drilling program, which were some $\$ 18$ million (EE-2 and EE-3).** At the $10000-\mathrm{ft}$ level, RGI drilling costs

*This range is attributable to variations in contingency factors used in the
RGI drilling cost code. ${ }^{\star \star}$ See Table II. 
approximate the Lab's drilling costs with the use of a $50 \%$ contingency factor on drilling time--RGI costs are $\$ 10.9$ million (see Table XIX) compared with $\$ 10.8$ million for the Lab's GT-2 and EE-1. Of course, our analyses demonstrate the feasibility of the HDR system with contingency factors of almost $100 \%$. Further, base case assumptions concerning future annual rates of increase in real oil costs and drilling costs--3\% and 4.34\%, respectively--must be viewed as most conservative in terms of their effects on net benefits attributable to the HDR system. Still another source for understating net benefits in the base case is the use of a $7.25 \%$ discount rate.* These considerations suggest that, notwithstanding uncertainties surrounding contingencies for drilling costs, the treatment of drilling costs in this work is sufficiently conservative to justify their use as credible estimates for assessing the space heat application of interest.

Second, reservoir design and reservoir performance are particularly important considerations in assessments of net benefits attributable to the HDR system. Here again, efforts are made in this work to use parameters which may understate the potential of the system. Thus, small fractures (164-ft diameter) are assumed; minimum reservoir design configurations (2 to 3 fractures) are considered in the analyses; and system management is limited to the control of well flow rates.

With the analytical setting implied by the above considerations, attention is now turned to two sets of conclusions that follow from study results described in Secs. $V$ and VI. The first set of conclusions relates to the feasibility of using HDR resources for space heat in terms of the WFC case study. The second set generalizes these results and relates to the conditions under which the use of HDR resources for space heat might be feasible in other locations.

A. Space Heat from HDR Resources at the Wallops Flight Center

Data in Table XXIII summarize the conditions under which the HDR space heat application is economically feasible at NASA's WFC--that is, the WFC's space heat requirements are less costly when provided by HDR resources than with their conventional oil-using steam system. From these data we may conclude the following.

*While future benefits and costs are discounted, our analyses demonstrate the preponderance of future benefit flows relative to future costs; thus, discounting effects are much more important for system benefits. 
(1) The HDR system is economically feasible under our base case assumptions.

(2) The HDR system is economically feasible with but one fracture (in contrast to 4 fractures used in the base case) when the preheat option is used; the system is feasible with only 3 fractures without the preheat option.

(3) The HDR system is feasible even under conditions where real drilling costs increase at more than twice the rate of oil costs.

(4) The HDR system remains feasible with contingency factors on drilling time of close to $100 \%$.

(5) The HDR system is feasible with temperature drawdown that is twice as rapid as the rate used in the base case.

The fact that the HDR system is feasible with but one fracture suggests the relatively immediate potential for the HDR technology developed at the Lab; this follows from the fact that it has already demonstrated the technology for creating the single-fracture system. Of course, the feasibility of the one-fracture system depends upon other base case assumpions, particularly, relatively low contingency factors and rates for temperature drawdown. As we have seen, the HDR system remains feasible with much higher rates of temperature drawdown (double the base case rates) and high contingency factors with larger reservoir surface areas--more fractures; the HDR system is shown to be feasible under almost any set of circumstances if the reservoir surface area can be expanded from about 1 million square feet (the rock surface area with one fracture) to 4 million square feet to $7 \mathrm{million}$ square feet (4 to 7 fractures). Given the enormous potential of this energy resource--discussed in more detail below--these observations point to the urgency for the Lab's completion of on-going experimental research designed to develop multiple fracturing techniques.

\section{B. Generalizing the Results}

At the outset of this study, it was noted that a number of conditions peculiar to the WFC.case study worked against the potential feasibility of providing space heat with the use of HDR geothermal resources. Depth to basement rock is large at the WFC site $(9000 \mathrm{ft}$ ) compared to depths one would commonly encounter $(2000$ to $6000 \mathrm{ft})$; the geothermal gradient at the WFC site-- $30^{\circ} \mathrm{C} / \mathrm{km}--$ is low relative to gradients found in many locations $--40^{\circ} \mathrm{C} / \mathrm{km}$ and higher (the gradient at the Lab's Fenton $\mathrm{Hill}$ site is $60^{\circ} \mathrm{C} / \mathrm{km}$. Further, 
TABLE XXIII

SUMMARY OF RESULTS: THE WFC CASE STUDY

\begin{tabular}{|c|c|c|c|c|c|c|c|}
\hline \multirow[b]{2}{*}{ Scenario } & \multicolumn{3}{|c|}{$\begin{array}{l}\text { HDR System } \\
\left(10^{6} 1980 \$\right)\end{array}$} & \multirow{3}{*}{$\begin{array}{l}\text { Reservoir } \\
\text { Design: } \\
\text { No. of } \\
\text { Fractures } \\
4\end{array}$} & \multirow{3}{*}{$\begin{array}{c}\begin{array}{c}\text { Initial } \\
\text { Drilling } \\
\text { Depth } \\
\text { (ft) }\end{array} \\
11699\end{array}$} & \multicolumn{2}{|c|}{ Initial Year } \\
\hline & $\begin{array}{c}\text { Gross } \\
\text { Benefits }\end{array}$ & Costs & $\begin{array}{c}\text { Net } \\
\text { Benefits }\end{array}$ & & & Re-Drilling & Preheating \\
\hline Base case & 15.0 & 10.9 & 4.1 & & & -- & 30 \\
\hline $\begin{array}{l}\text { Base case with } \\
\text { minimum reservoir } \\
\text { design: } \\
\text { with preheat } \\
\text { no preheat }\end{array}$ & $\begin{array}{l}15.0 \\
15.0\end{array}$ & $\begin{array}{l}14.9 \\
12.1\end{array}$ & $\begin{array}{l}0.1 \\
2.9\end{array}$ & $\begin{array}{l}1 \\
3\end{array}$ & $\begin{array}{ll}11 & 273 \\
13 & 415\end{array}$ & $\overline{17}$ & $\begin{array}{r}4 \\
--\end{array}$ \\
\hline $\begin{array}{l}\text { Relative (to oil } \\
\text { prices) increase in } \\
\text { real drilling costs: } \\
0.75 \\
3.00\end{array}$ & $\begin{array}{l}17.0 \\
13.3\end{array}$ & $\begin{array}{l}13.0 \\
14.5\end{array}$ & $\begin{array}{r}4.0 \\
-1.2\end{array}$ & $\begin{array}{l}3 \\
3\end{array}$ & $\begin{array}{l}11557 \\
11557\end{array}$ & $\begin{array}{l}18 \\
18\end{array}$ & -- \\
\hline $\begin{array}{l}\text { Contingency factors } \\
\text { for drilling in } \\
\text { permeable/impermeable } \\
\text { mater } i \text { al: } \\
50 \% / 50 \% \\
100 \% / 100 \%\end{array}$ & $\begin{array}{l}15.0 \\
15.0\end{array}$ & $\begin{array}{l}13.2 \\
15.7\end{array}$ & $\begin{array}{r}1.8 \\
-0.7\end{array}$ & $\begin{array}{l}4 \\
4\end{array}$ & $\begin{array}{ll}11 & 699 \\
11 & 699\end{array}$ & -- & $\begin{array}{l}30 \\
30\end{array}$ \\
\hline $\begin{array}{l}\text { Double temperature } \\
\text { drawdown: } \\
\text { with optimal reservoir } \\
\text { design } \\
\text { with minimal reservoir } \\
\text { design }\end{array}$ & 15.0 & 13.7 & 1.3 & 4 & 13557 & $\begin{array}{l}-- \\
--\end{array}$ & 11 \\
\hline
\end{tabular}

heating loads larger than the WFC's $72.8\left(10^{9}\right)$ Btu/year may be found in more centralized locations.* One obvious remaining question should be addressed here. What about the economic feasibility of using HDR resources for space heat applications under more favorable conditions?

Data relevant for responding to this question are given in Table XXIV. Consider, first, the case where heating loads are increased by $50 \%$ (to $109.2\left(10^{9}\right)$ Btu/year) over the WFC's annual requirement of $72.8\left(10^{9}\right)$ Btu/year. Under this case, gross benefits are nearly double system costs, and net benefits of $\$ 11.1$ million are attributable to the HDR resource system--this level of space heat requirements is satisfied at about half the cost of the conventional oil system. Given the net benefits to the HDR system with this larger heat load, the HDR system would be feasible regardless of changes in drilling costs, contingencies in drilling, and/or rates of temperature drawdown.

With depth to basement in the 2400 - to $5700-\mathrm{ft}$ range, and a geothermal temperature gradient of only 35 to $40^{\circ} / \mathrm{km}$, gross benefits are almost double

\footnotetext{
*Also, the dispersion of the WFC's buildings requires much higher costs for distribution pipes than would be the case with more concentrated heat loads.
} 
TABLE XXIV

SUMMARY OF RESULTS RELATED TO GENERAL SPACE HEAT APPLICATIONS FOR HDR RESOURCES

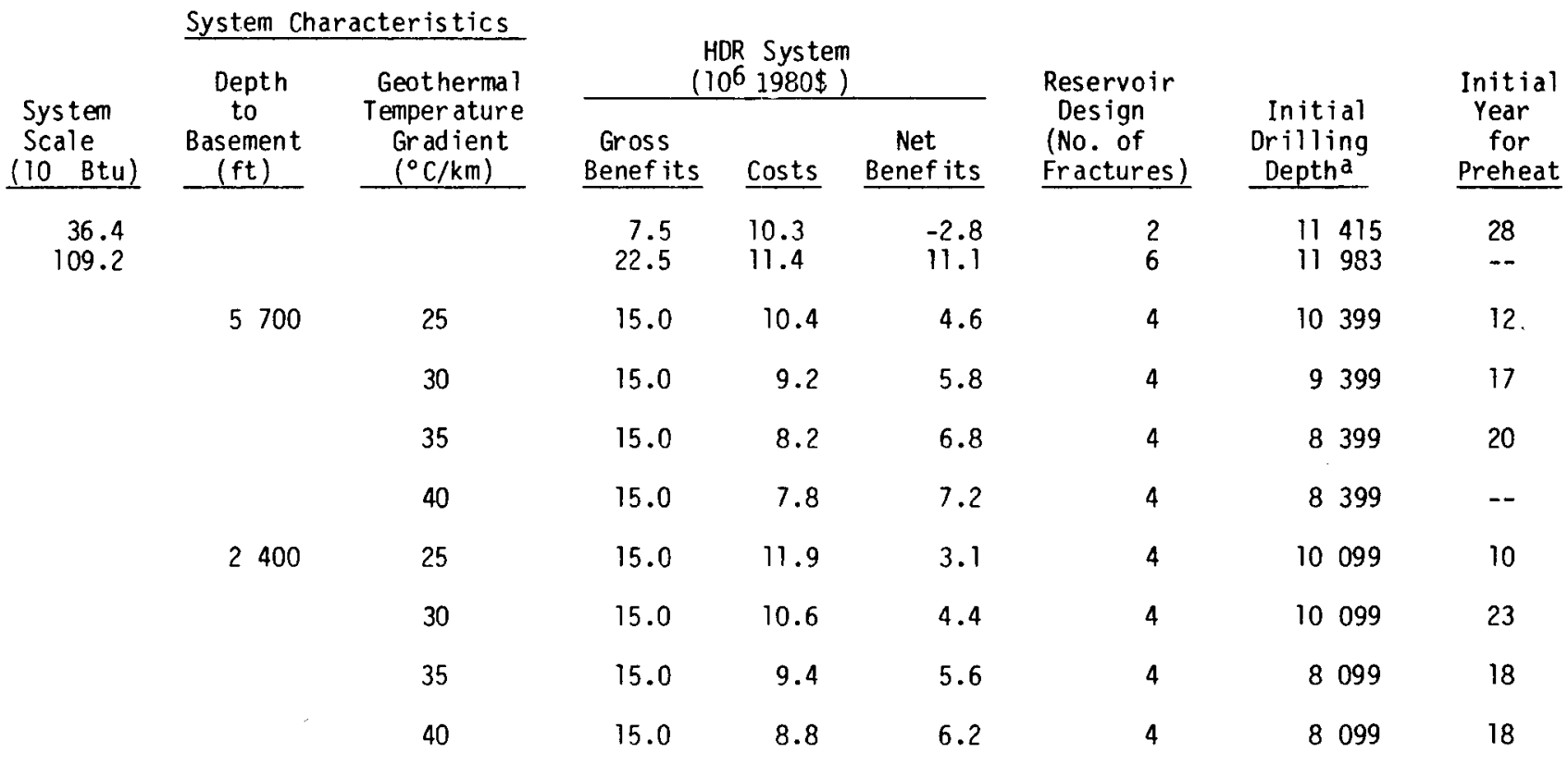

a No re-drilling.

system costs-- as above, HDR costs are about half the costs of conventional systems--and net benefits of $\$ 6$ to $\$ 7$ million are obtained. Here again, net benefits are sufficiently large to absorb costs associated with uncertainties concerning drilling contingencies and rates of temperature drawdown.

Thus, we have shown that the HDR resource can be economically feasible in providing space heat requirements for the WFC under a wide range of economic and technical conditions. The HDR resource is clearly feasible under more general conditions with lower depth to basement and somewhat higher geothermal temperature gradients.

These observations serve to identify the large social benefits that would attend access to this virtually omnipresent energy resource as a source for space and process heat.* Recognition of these potential returns should

*Similiar benefits may attend the use of HDR resources for generating electricity; see Cummings and Morris.1 
serve as an impetus for the Lab for the timely completion on ongoing $R \&$ efforts, designed to prove drilling technologies, reservoir design techniques, and reservoir management practices. 
A computer program for estimating drilling costs for liquid/vapor dominated geothermal system was developed at the Battelle Pacific Northwest Laboratories in 1975.* The updated computer code was not available at the time that this report was prepared; a sampling of updated cost estimates for depths between 0.5 and 3 kilometers was provided by Battelle personnel, * however, and these data are given in Table A-I. Regression techniques were applied to these data in an effort to develop continuous drilling cost functions, relating drilling costs to depth of drilling; these functions are given below. with appropriate $r^{2}$ measures. High $r^{2}$ values suggest goodness-of-fit of estimated values compared with data given in Table A-I in the $r$ ange of 0.5 to $3 \mathrm{~km}$.

For any given drilling depth, the geocost function for medium rock hardness--C (medium)--is used to basement depth, and C (Hard) is used for drilling costs for drilling in granite. Resulting cost estimates are then doubled to provide cost estimates for well pairs.

The following estimated geocost drilling cost functions are in thousands of 1980 dollars for one well.

$$
\begin{array}{ll}
C \text { (Soft) } & =108.4746579 \mathrm{e}^{0.8729852 D} \\
r^{2}=0.9989 & =116.0894471 \mathrm{e}^{0.951723819 D} \\
C \text { (Medium) } & \\
\mathrm{R}^{2}=0.9975 & \\
C \text { (Medium Hard) }=117.7297704 \mathrm{e}^{1.057297303 D} \\
r^{2}=0.9973 \\
C(\text { Hard }) \\
r^{2}=0.9968
\end{array}
$$

${ }^{\star}$ See Ref. 5 .

** Linda Fosbender, Battelle Pacific Northwest Laboratories, telephone commun ication, June 18,1981 . 
TABLE A-I

ESTIMATED DRILLING COSTS FROM UPDATED GEOCOST PROGRAM: ALTERNATIVE ROCK HARDNESS

\begin{tabular}{ccccc}
$\begin{array}{c}\text { Drilling } \\
\text { Depth } \\
(\mathrm{km})\end{array}$ & \multicolumn{5}{c}{$\begin{array}{c}\text { Est timated Drilling Costs with Rock Hardness } \\
\left(10^{3} \text { 1980\$ for one well) }\right.\end{array}$} \\
\cline { 2 - 6 } 0.5 & Soft & $\frac{\text { Medium }}{174}$ & $\frac{\text { Medium Hard }}{\text { Hard }}$ & $\frac{192}{198}$ \\
1.0 & 246 & 294 & 330 & 372 \\
1.5 & 396 & 474 & 588 & .726 \\
2.0 & 636 & 810 & 1062 & 1260 \\
2.5 & 996 & 1380 & 1770 & 2154 \\
3.0 & 1452 & 1848 & 2520 & 3229
\end{tabular}

SOURCE: Linda Fosbender, Battelle Pacific Northwest Laboratories, telephone communication, June 18, 1981. 
The RGI drilling cost program is an extraordinarily detailed study of drilling costs for HDR reservoirs. Given the study's detail, only a sketch of the program can be presented here; the interested reader is referred to the complete RGI report ${ }^{6}$ for additional details.

A sample of some of the log parameters in the RGI program is given in Table B-I. From these data, drilling cost estimates are seen to vary with such things as drill penetration rates, drilling techniques, rates of angle build-up, and distance to contractors. Penetration rates used in this study are based on RGI's worst case assumptions; for example, with bit size between $171 / 2$ in and 26 in and drilling in permeable rock, the RGI range for penetration rates is 7 to $25 \mathrm{ft} / \mathrm{h}$. The lower, worst case, rate of $7 \mathrm{ft} / \mathrm{h}$ is used here.

Components of RGI drilling costs are given in Table B-II for the base case. The base case involves initial drilling to $11699 \mathrm{ft}, 4 \mathrm{fractures,}$ and drilling costs of $\$ 8.7$ million. Components of the $\$ 8.7$ million in drilling costs are seen in Table B-II. "G \& A" costs refer to general and accounting costs.

Drilling time is, of course, a major determinant of drilling costs--factors related to drilling time account for some $65 \%$ to $70 \%$ of total drilling costs. A general appreciation for the structure of RGI drilling costs may then be gained by a close examination of the RGI casing program and drilling time program. Relevant data for these programs--applicable to the base case--are given in Table B-III.

Before examining data in Table B-III, it is useful to understand the six drilling segments used for calculating drilling time. These segments, denoted $D_{1}-D_{6}$, are explained as follows and are shown graphically in Fig. B-1. In what follows, depth refers to length of well bore (after $D_{4}$ ) rather than vertical depth.

$D_{1}: \quad$ initial borehole established with diameter of 26 in. is drilled to $184 \mathrm{ft}$--cased with $20-$ in-diam pipe. 
$\mathrm{D}_{2}$ : within the $\mathrm{D}_{1}$ casing, to borehole with $171 / 2-$ in diam is drilled to a depth of $1840 \mathrm{ft}--$ this borehole is cased with 13.6-in-diam pipe for the entire $1840 \mathrm{ft}$.

$\mathrm{D}_{3}: \quad 12.3$-in-diam borehole is from $1840 \mathrm{ft}$ to basement rock.

$D_{4}: \quad 200-\mathrm{ft}$ extension of $\mathrm{D}_{3}$ into basement rock--is required before directional drilling can be initiated, 9.6-in casing from the surface through $D_{3}$ and $D_{4}(9200 \mathrm{ft})$.

D5: directional drilling is initiated; at $0.02^{\circ} / \mathrm{ft}, 1500 \mathrm{ft}$ required to establish $30^{\circ}$ angle. "Hangers" are used to insert casing "liners" into the injection well (only) for $D_{5}$ and $D_{6}$.

$D_{6}$ : area is drilled at constant, $30^{\circ}$ angle. First fracture is created after drilling additional $1578 \mathrm{ft}$ at constant angle. Remaining $508 \mathrm{ft}$ are required to establish 3 additional fractures and to allow for an $82-\mathrm{ft}$ "rat hole" space.*

For the base case shown in Fig. B-1, vertical depth to the bottom of the fourth fracture is $12786 \mathrm{ft}$; length of the borehole $13018 \mathrm{ft}$. Vertical depth to the center of the last (fourth) fracture is $11699 \mathrm{ft}$--the depth referred to as "initial drilling depth" in the text of this report. Thus, initial drilling depth, as used in the text, is a "temperature" depth inasmuch as this is the relevant depth for determining average reservoir temperature by geothermal temperature gradients.

Given the above definitions, one can easily interpret the RGI casing program given in Table B-III. Drilling time (in hours) for each drilling segment is given in Table B-III. For the base case, each will require 44 days of drilling in permeable rock; injection and production wells require 149 and 129 total rig days, respectively (includes drilling and non-drilling time).

${ }^{*}$ Drilling debris and tools accumulate in this space. 
TABLE B-I

SAMPLE OF KEY PARAMETERS IN THE

RGI DRILLING COST PROGRAM

Par ameter

Study Value

Fracture

No.

height

horizontal distance between fractures

Whipstock directional drilling technique:

distance between whipstock runs

angle (from vertical) of directional drilling

rate of angle build-up

Round tripping time (constant)

Distance to contractors

Costs

plugging/operation

fracturing/fracturea

varied

$360 \mathrm{~m}$

$164 \mathrm{ft}$

$100 \mathrm{ft}$

$30^{\circ}$

$0.02^{\circ} / \mathrm{ft}$

$11 / 2 \mathrm{~h}$

$250 \mathrm{mi}$

$\$ 358 \quad 160$

$\$ 60000$ to $\$ 100000$

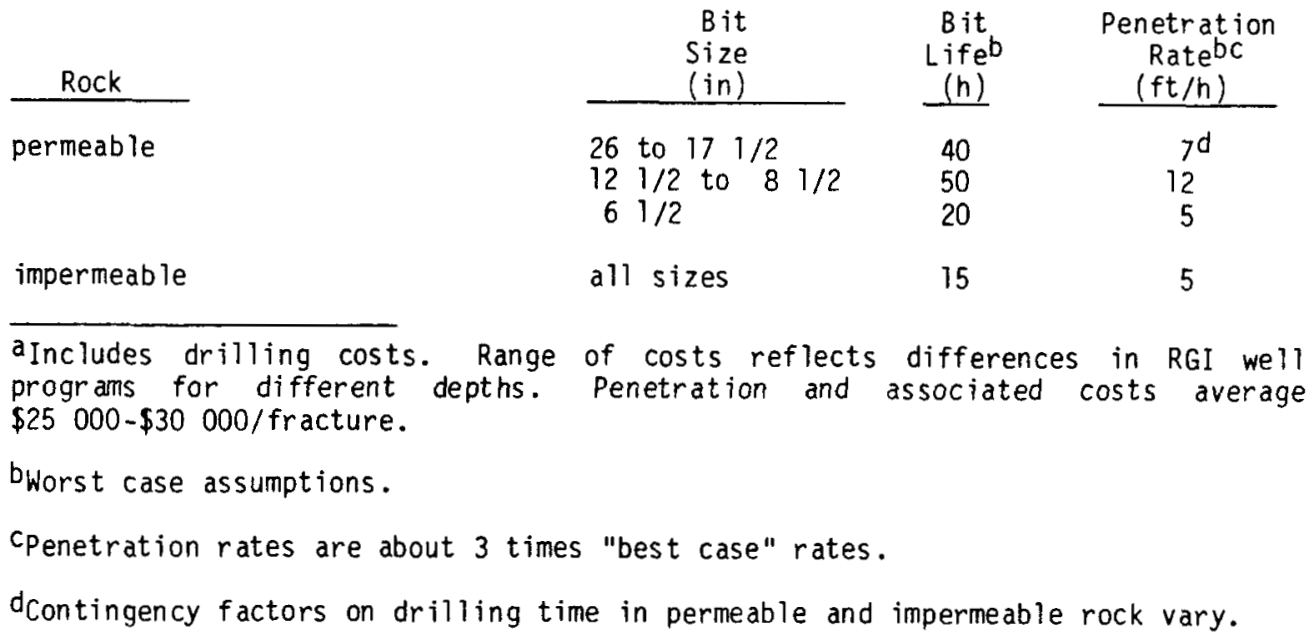


TABLE B-II

COMPONENTS OF RGI DRILLING COST ESTIMATES (9 $000-\mathrm{ft}$ basement, total drilling to $11700 \mathrm{ft}$ )

Costs

\section{Location $\cos t$}

Cost Component

Move $\cos \mathrm{t}$

Rig mobilization cost

Rig fuel cost

Water supply setup charges

Water well cost

Correlating \& perforating

Packer, BOP, \& Scraper

Completion rig cost

Pump truck service

Portable derrick

Rental equip. \& trans.

Casing transportation

Drilling fluid transportation

Additional transportation

Supervision \& Co. Labor

Incidental costs

$G \& A$ Costs

Total Common Costs (1980\$)

\section{$\frac{\text { Cost Component }}{\text { Wellhead \& liner hangers }}$}

Total tangible costs

Tax on tangibles

$17 \quad 424$

483120

18304

9504

$77 \quad 440$

17600

38544

15136

93632

30448

$98 \quad 384$

9504

23584

380160

$50 \quad 688$

490336

1943040

\begin{tabular}{|c|c|}
\hline Injector & Producer \\
\hline 48576 & 62128 \\
\hline 467456 & 519024 \\
\hline 18656 & 20768 \\
\hline 2073280 & 1779008 \\
\hline $405 \quad 504$ & $386 \quad 496$ \\
\hline 20240 & 18832 \\
\hline 1232 & 1056 \\
\hline 75856 & 73392 \\
\hline 105248 & 105248 \\
\hline 152592 & 176704 \\
\hline 48928 & $46 \quad 288$ \\
\hline 8272 & 9680 \\
\hline 19712 & 18832 \\
\hline 31680 & 24640 \\
\hline 108976 & 834064 \\
\hline 4586208 & $4076 \quad 160$ \\
\hline $\begin{array}{lll}8 & 662 & 368\end{array}$ & \\
\hline
\end{tabular}


TABLE B-III

EXAMPLE OF RGI CASING AND DRILLING PROGRAMS:

BASE CASE

RGI Casing Program

\begin{tabular}{|c|c|c|c|c|}
\hline \multirow[b]{2}{*}{$\begin{array}{l}\text { Depth } \\
\text { Segment } \\
\end{array}$} & \multirow[b]{2}{*}{$(\mathrm{ft})$} & \multicolumn{3}{|c|}{$\begin{array}{c}\text { Diameter } \\
\text { (in) }\end{array}$} \\
\hline & & Hole & $\begin{array}{c}\text { In ject jon } \\
\text { Well } \\
\end{array}$ & $\begin{array}{c}\text { Production } \\
\text { Well }\end{array}$ \\
\hline$D_{1}:$ & 184 & 26 & 20 & 20 \\
\hline $\mathrm{D}_{2}:$ & 1840 & 17.5 & 13.58 & 13.58 \\
\hline$D_{3}, D_{4}:$ & 9200 & 12.3 & 9.6 & 9.6 \\
\hline$D_{5}, D_{6}:$ & 3586 & 8.5 & 7.0 & n.a. \\
\hline
\end{tabular}

RGI Drilling Progr amb

\begin{tabular}{|c|c|c|c|c|}
\hline \multicolumn{5}{|c|}{$\begin{array}{c}\text { Injector well } \\
\text { (Production Well) } \\
(h)\end{array}$} \\
\hline & $\begin{array}{l}\text { Non-Rig } \\
\text { Time } \\
\end{array}$ & Rig Time & $\begin{array}{l}\text { Drilling } \\
\text { Trips }\end{array}$ & $\begin{array}{l}\text { Bids } \\
\text { Used }\end{array}$ \\
\hline $\mathrm{D}_{1}$ & $\begin{array}{c}43.9 \\
(43.9)\end{array}$ & $\begin{array}{c}29.7 \\
(29.7)\end{array}$ & $\begin{array}{c}1 \\
(1)\end{array}$ & $\begin{array}{c}2 \\
(2)\end{array}$ \\
\hline $\mathrm{D}_{2}$ & $\begin{array}{c}40.6 \\
(40.6)\end{array}$ & $\begin{array}{c}265.0 \\
(265.0)\end{array}$ & $\begin{array}{c}6 \\
(6)\end{array}$ & $\begin{array}{c}7 \\
(7)\end{array}$ \\
\hline$D_{3}$ & $\begin{array}{c}76.9 \\
(76.9)\end{array}$ & $\begin{array}{c}752.7 \\
(752.7)\end{array}$ & $\begin{array}{c}12 \\
(12)\end{array}$ & $\begin{array}{l}13 \\
113\end{array}$ \\
\hline $\mathrm{D}_{4}$ & $\begin{array}{l}155.8 \\
(55.5)\end{array}$ & $\begin{array}{l}288.5 \\
(27.0)\end{array}$ & $\begin{array}{c}4 \\
(1)\end{array}$ & $\begin{array}{c}5 \\
(2)\end{array}$ \\
\hline $\mathrm{D}_{5}$ & & $\begin{array}{c}1474.3 \\
(1418.2)\end{array}$ & $\begin{array}{c}18 \\
(18)\end{array}$ & $\begin{array}{c}7 \\
(7)\end{array}$ \\
\hline $\mathrm{D}_{6}$ & & $\begin{array}{c}355.0 \\
(293.4)\end{array}$ & $\begin{array}{c}5 \\
(4)\end{array}$ & $\begin{array}{c}6 \\
(5)\end{array}$ \\
\hline
\end{tabular}

asee Fig. B-1.

bDays in permeable rock: injector we 11, 44; production wel1, 44; drilling rig days: injector well, 149; production well, 129. 
EARTH SURFACE

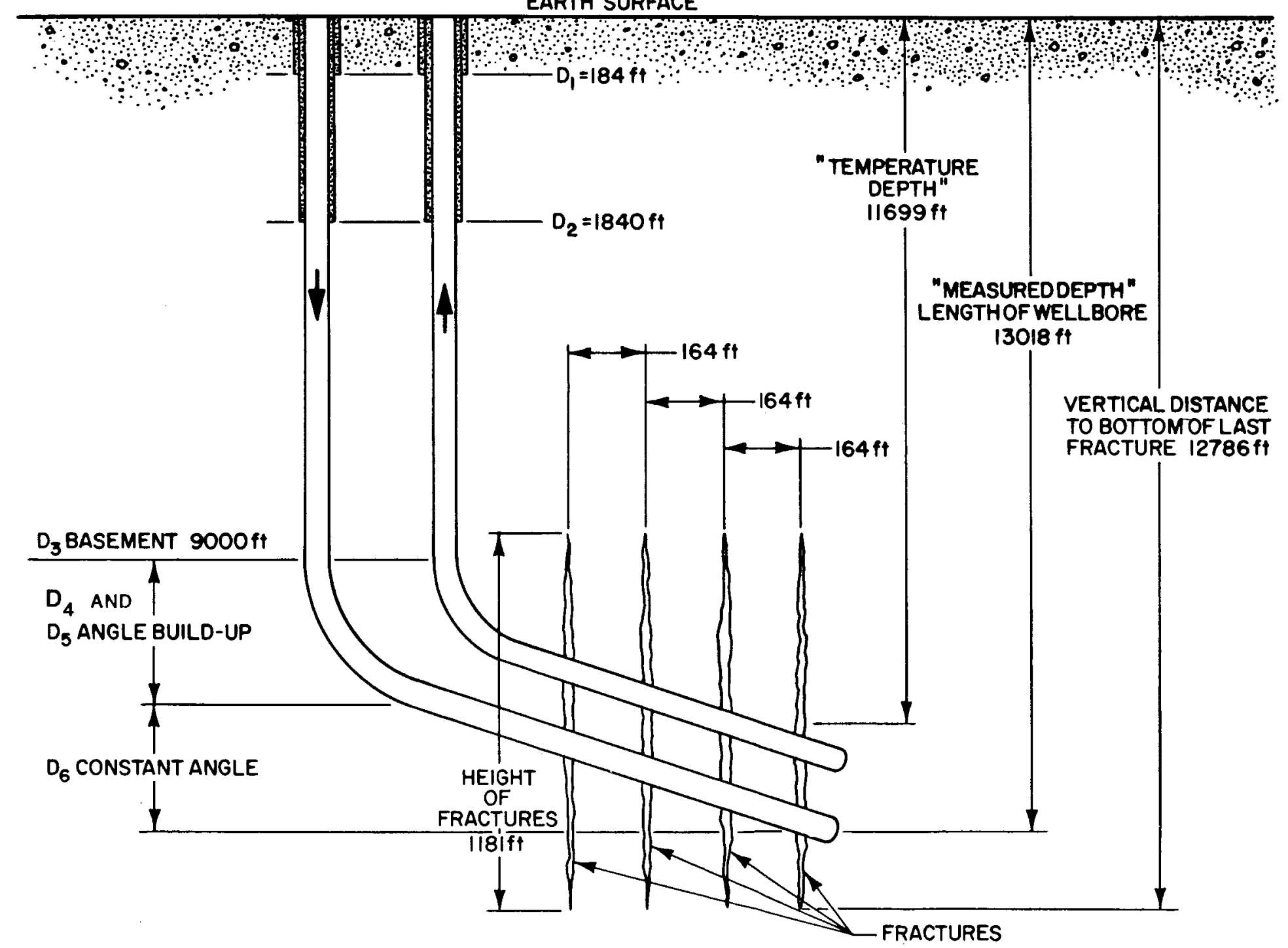

Fig. B-1. Schematic of HDR reservoir geometry base case. 
The purpose of this appendix is to survey general factors affecting oil and drilling costs and to discuss estimates for future rates of increase in real--inflation-free--oil and drilling costs. No pretense is made here for an in-depth analysis for estimating future costs, given the limited scope of this study.

A. Drilling Costs

The costs of drilling deep wells have steadily accelerated in recent years, even when discounted for the general rate of inflation. Perhaps the most striking example concerns the costs of drilling deep wells. Table C-I shows how those costs have jumped since 1978.

A slightly longer view of trends in well costs is afforded by the data in the American Petroleum Institute's Joint Association Survey on Drilling Costs. ${ }^{8}$ Those data reveal that the US average drilling cost per foot, for oil, gas, and dry wells, increased from $\$ 13.01$ in 1960 to $\$ 17.56$ in 1969 , to $\$ 28.93$ in 1974 , and to $\$ 67.70$ in 1979 . In terms of annual rates of increase, those figures are equivalent to $9.1 \%$ for the past 19 years, $14.5 \%$ for the past ten years, and $18.5 \%$ for the past five years. Table C-II presents real rates of cost increase, deflating for the change in the implicit GNP deflator.

TABLE C-I

COSTS OF ORILLING DEEP WELLS FOR OIL AND GAS

\begin{tabular}{|c|c|c|c|c|c|c|}
\hline \multirow{3}{*}{$\begin{array}{r}\text { Well } \\
\text { Depth } \\
\text { (ft) }\end{array}$} & \multirow[b]{3}{*}{ Year } & \multirow[b]{3}{*}{$\begin{array}{l}\text { No. of } \\
\text { Welis }\end{array}$} & \multicolumn{3}{|c|}{ Average } & \multirow{3}{*}{$\begin{array}{l}\text { Rate of } \\
\text { Increase } \\
(\% \$ / \mathrm{ft})\end{array}$} \\
\hline & & & \multirow{2}{*}{$\begin{array}{r}\text { Well } \\
\text { Depth } \\
(\mathrm{ft}) \\
\end{array}$} & \multicolumn{2}{|l|}{$\cos t$} & \\
\hline & & & & $\left(10^{6} \$ /\right.$ we 11$)$ & $(\$ / \mathrm{ft})$ & \\
\hline At least & $\begin{array}{l}1978 \\
1979 \\
1980\end{array}$ & $\begin{array}{l}600 \\
621 \\
859\end{array}$ & $\begin{array}{ll}17 & 140 \\
17 & 246 \\
17 & 178\end{array}$ & $\begin{array}{ll}2 & 587 \\
3 & 599 \\
4 & 560\end{array}$ & $\begin{array}{l}150.93 \\
208.68 \\
265.47\end{array}$ & $\begin{array}{l}38.3 \\
27.2\end{array}$ \\
\hline $\begin{array}{l}\text { At least } \\
20000\end{array}$ & $\begin{array}{l}1978 \\
1979 \\
1980\end{array}$ & $\begin{array}{l}59 \\
64 \\
81\end{array}$ & $\begin{array}{ll}21 & 162 \\
21 & 566 \\
21 & 645\end{array}$ & $\begin{array}{ll}4 & 303 \\
6 & 932 \\
8 & 361\end{array}$ & $\begin{array}{l}203.32 \\
321.41 \\
386.27\end{array}$ & $\begin{array}{l}58.1 \\
20.2\end{array}$ \\
\hline
\end{tabular}

SOURCE: Ref. 17. 
TABLE C-II

ANNUAL RATES OF CHANGE OF DRILLING COSTS, US AVERAGE

COST PER FOOT, AND THE GNP PRICE INDEX

\begin{tabular}{|c|c|c|c|}
\hline Years & $\begin{array}{c}\text { Drilling } \\
\text { Cost per Foot } \\
(\%) \\
\end{array}$ & $\begin{array}{c}\text { GNP } \\
\text { Def lator } \\
(\%) \\
\end{array}$ & $\begin{array}{c}\text { Real } \\
\text { Drilling } \\
\text { Cost } \\
(\%) \\
\end{array}$ \\
\hline 1960 to 1979 & 9.1 & 4.7 & 4.2 \\
\hline 1969 to 1979 & 14.5 & 6.5 & 7.5 \\
\hline 1974 to 1979 & 18.5 & 7.0 & 10.8 \\
\hline
\end{tabular}

SOURCE: Computed from data in Table C-III.

On the basis of Table C-II, a naive projection of future real increases in drilling costs might encompass the range $4.2 \%$ to $10.8 \%$ per year, with a mean forecast somewhere near $7.5 \%$.

To place these data in perspective, it is useful to consider a few simple, statistical models as a means for examining possible implications of past trends in drilling costs. Before discussing the models, it should be pointed out that national average drilling costs are influenced by the changing proportions of $0 i 1$ and gas wells and of onshore and offshore wells. Therefore, a somewhat more uniform measure of drilling costs over time is provided by the data on gas wells only in Table C-III. As may be computed from that table, the real drilling costs per foot for gas wells increased at the following compound annual rates: $2.7 \%$, 1960 to $1979 ; 5.9 \%$, 1969 to 1979; and $9.4 \%, 1974$ to 1979. These figures are somewhat lower than the ones quoted above, and they probably are more relevant, owing to the greater uniformity of the concept being measured. For the statistical models, we start with the all-well drilling costs, and then we re-estimate the models with data for gas wells alone.

For Model 1, drilling costs per foot may be hypothesized to depend primarily on the overall rate of inflation and the number of wells drilled per year. The latter is important as a measure of short-term scarcity of drilling capacity. Using the data for all wells in Table C-III, the following 
TABLE C-III

WELL DRILLING COSTS IN THE US: 1960 to 1979

\begin{tabular}{|c|c|c|c|c|c|}
\hline \multirow[b]{2}{*}{ Year } & \multicolumn{2}{|c|}{$\begin{array}{l}\text { All } 0 i l, \text { Gas, } \\
\text { and Dry Wells }\end{array}$} & \multicolumn{2}{|c|}{$\begin{array}{c}\text { Onshore Gas } \\
\text { Wells Only }\end{array}$} & \multirow[b]{2}{*}{$\begin{array}{c}\text { US GNP } \\
\text { Def lator } \\
\text { Index } \\
(\%) \\
\end{array}$} \\
\hline & $\begin{array}{c}\operatorname{Cos} t \\
(\$ / f t) \\
\end{array}$ & $\begin{array}{l}\text { Average } \\
\text { Depth } \\
(\mathrm{ft}) \\
\end{array}$ & $\begin{array}{c}\text { Cost } \\
(\$ / f t) \\
\end{array}$ & $\begin{array}{l}\text { Average } \\
\text { Depth } \\
(\mathrm{ft})\end{array}$ & \\
\hline 1960 & 13.01 & 4156 & 17.39 & 5417 & 68.7 \\
\hline 1961 & 12.85 & 4216 & 16.63 & $\begin{array}{lll}5 & 271\end{array}$ & 69.3 \\
\hline 1962 & 13.31 & 4309 & 16.96 & 5254 & 70.6 \\
\hline 1963 & 12.69 & 4312 & 15.93 & 5252 & 71.7 \\
\hline 1964 & 12.86 & 4326 & 17.21 & 5473 & 72.8 \\
\hline 1965 & 13.44 & 4415 & 16.67 & 5396 & 74.3 \\
\hline 1966 & 14.95 & 4558 & 19.22 & 5932 & 76.8 \\
\hline 1967 & 15.97 & 4526 & 20.27 & 5847 & 79.1 \\
\hline 1968 & 16.83 & 4849 & 20.89 & 5894 & 82.5 \\
\hline 1969 & 17.56 & 5007 & 20.71 & 5732 & 86.8 \\
\hline 1970 & 18.84 & 5022 & 22.75 & 5764 & 91.4 \\
\hline 1971 & 19.03 & 4949 & 23.46 & 5749 & 96.0 \\
\hline 1972 & 20.76 & 5026 & 23.71 & 5.442 & 100.0 \\
\hline 1973 & 22.50 & 5146 & 24.56 & 5505 & 105.8 \\
\hline 1974 & 28.93 & 4843 & 31.36 & 5436 & 116.0 \\
\hline 1975 & 36.99 & 4761 & 41.06 & 5501 & 127.2 \\
\hline 1976 & 40.45 & 4643 & 44.00 & 5297 & 133.8 \\
\hline 1977 & 46.81 & 4819 & 49.74 & 5303 & 141.6 \\
\hline 1978 & 56.63 & 4875 & 58.25 & 5324 & 152.1 \\
\hline $1979 a$ & 67.70 & 4925 & 68.90 & $\begin{array}{ll}5337\end{array}$ & 162.8 \\
\hline
\end{tabular}

aThe compound annual rate of change for 1960 through 1979 is $9.1 \%$ for all wells, $7.5 \%$ for onshore $g$ as wells, and $4.65 \%$ for the GNP deflator.

SOURCE: Ref. 8. 
regressions were derived in terms of rate-of-change variables, over a sample of 19 yearly observations for 1961 to 1979 .

$$
\begin{aligned}
& R D C O S T=-3.0641+0.22508 \text { RWELL } \\
& (-1.2601)(1.8168) \\
& +2.6264 \text { RPGNP; } R^{2}=0.8287 \\
& \text { (5.3192) } \\
& \text { RDCOST }=-3.6805+0.23261 \text { RDFTG }+2.7161 \text { RPGNP; } \\
& (-1.6223)(1.7805) \quad(5.8123) \\
& R^{2}=0.8276
\end{aligned}
$$

where

$$
\begin{aligned}
& \text { RDCOST = } \text { annual rate of change of drilling costs per foot, US average for } \\
& \text { oil, gas, and dry wells. } \\
& \text { RWELL = } \text { annual rate of change of total number of wells drilling in the } \\
& \text { US. } \\
& \text { RPGNP = annual rate of change of the implicit GNP deflator. } \\
& \text { RDFTG = annual rate of change of the total footage drilled in the US. }
\end{aligned}
$$

T-ratios are given in parentheses.

The $\mathrm{R}^{2}$ values may not look particularly high for a time series analysis at first glance, but when it is realized that percentage-change variables are used, it can be seen that the $R^{2}$ are high indeed.

In applying these equations to forecasting questions, we would start from the fact that the estimated coefficients are elasticities because the equations are specified in percentage-change (log-derivative) form. In other words, drilling costs appear to be highly sensitive to inflation: a one-percentage-point increase in the rate of inflation causes drilling costs to rise by 2.6 to 2.7 percentage points. Drilling activity, whether measured in terms of wells or footage, does influence the cost at a statistically significant level, but the elasticity of costs with respect to activity is only 0.23 . 
To illustrate how this kind of model would be applied to forecasting, we may assume that annual drilling activity in the long run will not increase, and that the GNP deflator will increase by $3.0 \%$ to $6.0 \%$ per year. These assumptions give us preliminary low and high estimates for the long-run rates of increase of drilling costs [see Eq. (1).]

\section{Rate of Increase}

$(\%)$

$\begin{array}{lcccc}\text { Case } & \text { GNP Deflator } & \text { Nominal } & \begin{array}{r}\text { Rea } \\ \text { Drilling Costs }\end{array} & \text { Drilling } \\ & 3.0 & & 4.8 & 1.8 \\ \text { B } & 6.0 & 12.7 & 6.3\end{array}$

If drilling activity were to increase by, say, $0.4 \%$ per year (see below), then $0.1 \%$ should be added to the nominal drilling cost increase rate (giving $4.9 \%$ and $12.8 \%$ ), so that the real cost increases would become $1.8 \%$ and $6.4 \%$. No doubt US drilling activity will continue to increase in the short run, but it may level off or even decline in the longer run (as it did in much of the 1960s). If we take $4.5 \%$ as our median forecast of the annual US inflation rate, as measured by the GDP deflator, and allow for a $0.4 \%$ per year increase in drilling activity, then Model 1 's median forecast for the real rate of increase in drilling costs becomes $4.2 \%$.

Model 2 attempts to explain directly the rate of change in real drilling costs, rather than achieve it indirectly by statistical determination of the change in nominal drilling costs. The explanatory variables for Model 2 are the rate of change in real machinery costs, * the average well depth, and the rate of drilling activity in terms of numbers of wells. The estimated equation is

$$
\begin{aligned}
& \text { RDCOSTR }=1.6082+0.6992 R D E P T H+0.2130 R W E L L \\
& (1.6251)(1.9779) \quad(2.1379) \\
& +2.0176 R P M M R ; \quad R^{2}=0.7871 \\
& (4.5426)
\end{aligned}
$$

*For the purpose at hand, the costs of metal-working machinery are used because they may be considered to be typical of machinery costs and yet they do not include the concept we are trying to explain, which is the cost of drilling machinery (and drilling operations). 
where the new variables are

$$
\begin{aligned}
\text { RDCOSTR = } & \text { annual rate of change in real drilling costs per foot, US } \\
& \text { average for oil, gas, and dry wells, } \\
\text { RDEPTH = annual rate of change in the average well depth, and } & \text { RPMMR = annual rate of change in real machinery costs. }
\end{aligned}
$$

Equations (1) to (3) show that the cost-determination hypothesis is a reasonable one, for the statistical properties of the equations are satisfactory, and the signs of the coefficients are in accord with expectations. We now apply the model to data for the gas wells only.

$$
\begin{aligned}
& \text { RDCOSTG }=-3.4508+0.37108 \text { RONWELL }+1.4590 \text { RDEPTHG } \\
& \begin{array}{lll}
(-1.4740 \quad(2.6662) \quad(4.8367)
\end{array} \\
& +2.4117 \text { RPGNP; } R^{2}=0.8770 \text {, } \\
& (4.9694) \\
& F(3,16)=38.02(1960-79) \\
& \text { RDCOSTRG }=1.2779+0.27034 \text { RONWELL }+1.1810 \text { RDEPTHG } \\
& (1.5221)(2.2360) \quad(4.3745) \\
& +1.8186 \text { RPMMR; } R^{2}=0.8540, \\
& (4.3096) \\
& F(3,15)=29.25(1961-79)
\end{aligned}
$$

where the variables are defined as before but the suffix $G$ indicates gas wells only and RONWELL denotes the rate of change of the total annual number of onshore wells drilled.

As might be expected, these equations are more significant statistically than the previous ones, and they indicate a somewhat lower (but still high) elasticity of drilling costs with respect to general inflation. The elasticity of costs with respect to drilling activity remains between onequarter and one-half in all equations estimated. The cost elasticity with respect to depth is higher for the case of gas wells only, which should not be surprising in view of their greater average depth. We turn now to questions of forecasting with Eqs. (4) and (5). 
Historically, the changes in real machinery costs have been positive as illustrated by the annual rates of change in RPMMR over the following periods.

$\begin{array}{ll}1960 \text { to } 1970, & 0.7 \% ; \\ 1960 \text { to } 1979, & 1.0 \% ; \\ 1969 \text { to } 1979, & 1.8 \% \text {; and } \\ 1974 \text { to } 1979, & 3.2 \%\end{array}$

Similarly, wells have tended to go deeper on the average over time, so RDEPTH has registered positive changes.

$$
\begin{aligned}
& 1960 \text { to } 1970, \quad 1.9 \% \text {; and } \\
& 1960 \text { to } 1979, \quad 0.9 \% \text {. }
\end{aligned}
$$

But gas wells have not shown that same tendency, as seen by the rates of change in RDEPTHG.

1960 to $1970, \quad 0.6 \%$; and

1960 to $1979, \quad 0 \%$.

The rates of change of drilling activity have fluctuated more, and they

\begin{tabular}{|c|c|c|}
\hline - & $\begin{array}{c}\text { RWELL } \\
(\%) \\
\end{array}$ & $\begin{array}{l}\text { RONWELL } \\
(\%)\end{array}$ \\
\hline 1960 to 1970 & -5.2 & -5.0 \\
\hline 1969 to 1979 & 5.0 & 5.3 \\
\hline 1960 to 1979 & 0.4 & 0.4 \\
\hline
\end{tabular}
obviously are related to the domestic price of $0 i 1$.

For purposes of projection we may use Eqs. (4) and (5) along with the following alternate assumptions about the independent variables.

RPMMR : $\quad 1.0 \%, 2.0 \%$;

RONWELL: $\quad 0,3.0 \%$;

RDEPTHG: $\quad 0^{\star}$; and

RPGNP: $0,3.0 \%, 6.0 \%$.

These values result in the projections shown in Tables $C-I V$ and $C-V$. As may be seen from the tables, the naive forecasts presented above were too 
TABLE C-IV

ALTERNATE PROJECTIONS OF THE REAL

RATE OF INCREASE OF DRILLING COSTS

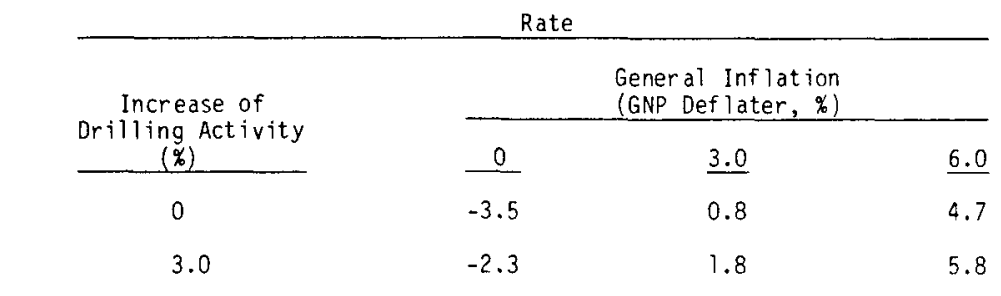

SOURCE: Eq. (4).

TABLE $C-V$

ALTERNATE PROJECTIONS OF THE REAL RATE OF INCREASE OF DRILLING COSTS

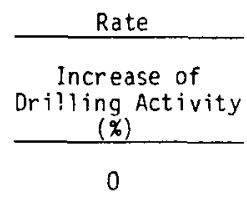

3.0

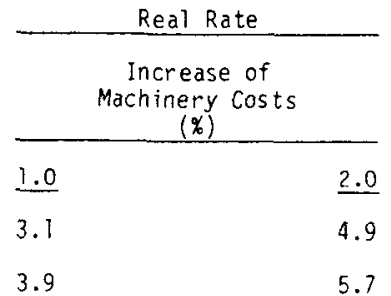

SOURCE: Eq. (5).

pessimistic. A mid-case forecast of the real annual rate of increase of drilling costs might be $2.0 \%$, with low and high cases of 0 and $4 \%$.

In conclusion, both Eqs. (4) and (5) yield the result that drilling costs are highly sensitive to inflation--whether measured by the GNP deflator or by the price index for machinery. More general explanations of the tendency for drilling costs to inflate rapidly may be sought in terms of both long-run and short-run phenomena. In the long run, two factors may be mentioned:

(a) the tendency for the machinery sector as a whole to experience more inflation than the rest of the economy;

(b) the fact that the US is a major exporter of drilling machinery and services, so that foreign demand tends to keep the domestic supply-demand situation tight.

In the shorter run, the high elasticity of real drilling costs with respect to real machinery costs suggests that the short-run demand for drilling is 
latively inelastic. This may well be true, for once an oil company commits itself to an exploration program, it is not likely to be deterred by a short-run increase in drilling costs.

Figure $\mathrm{C}-1$ shows the price consequences of an increase in input costs (supply costs), such as the costs of drilling machinery, under conditions of both elastic and inelastic demand. With the relatively elastic demand curve $D_{0}^{\prime}$, the price rises to $p_{1}^{\prime}$ from $p_{0}$. With the inelastic demand curve $D_{0}$, the price rises further to $p_{1}$.

Therefore, there are good reasons for expecting drilling costs to continue to inflate more rapidly than most goods and services in the economy. The models above give approximate estimates of the magnitude of that inflation. B. Future Trends in Wor $7 d$ il Prices

$0 i 1$ price increases have become accepted as a way of life, and they have formed the planning basis for substantial energy investments. However, a longer view of history reveals that price trends have displayed very different patterns in different periods. The real price of $0 i 1$ in fact declined from 1960 to 1972 before increasing sharply in 1973 to 1974 and again in 1979 to 1980 (Tables C-VI and C-VII). From 1973 to 1980, the official OPEC price of crude increased in real terns (deflated by the US GNP deflator) by $27.4 \%$ per year. The role of OPEC emerges in sharp relief from these figures, but the very success of $O P E C$ has set in motion three trends that may undermine its future ability to control prices: (a) the recent implementation of successful energy conservation measures in the industrial countries, (b) the upsurge in investment in alternate energy sources, and (c) the increase in rates of petroleum exploration and discovery in non-OPEC countries. Recent oil strikes have been particularly notable in Mexico and West Africa.

Some of these developments are reflected in the recent softening of oil prices. As of July 1981, the spot price for Saudi Arabian light crude was $\$ 3 / \mathrm{bbl}$ below the official price (Ref. 12, p. 15). The erratic behavior of the world oil market would seem to make price forecasting more difficult than usual, nevertheless analysts of the oil industry appear to have reached a remarkable consensus about the probable long-term trends in oil prices. The

*This variable is not directly relevant to the case of geothermal wells. 


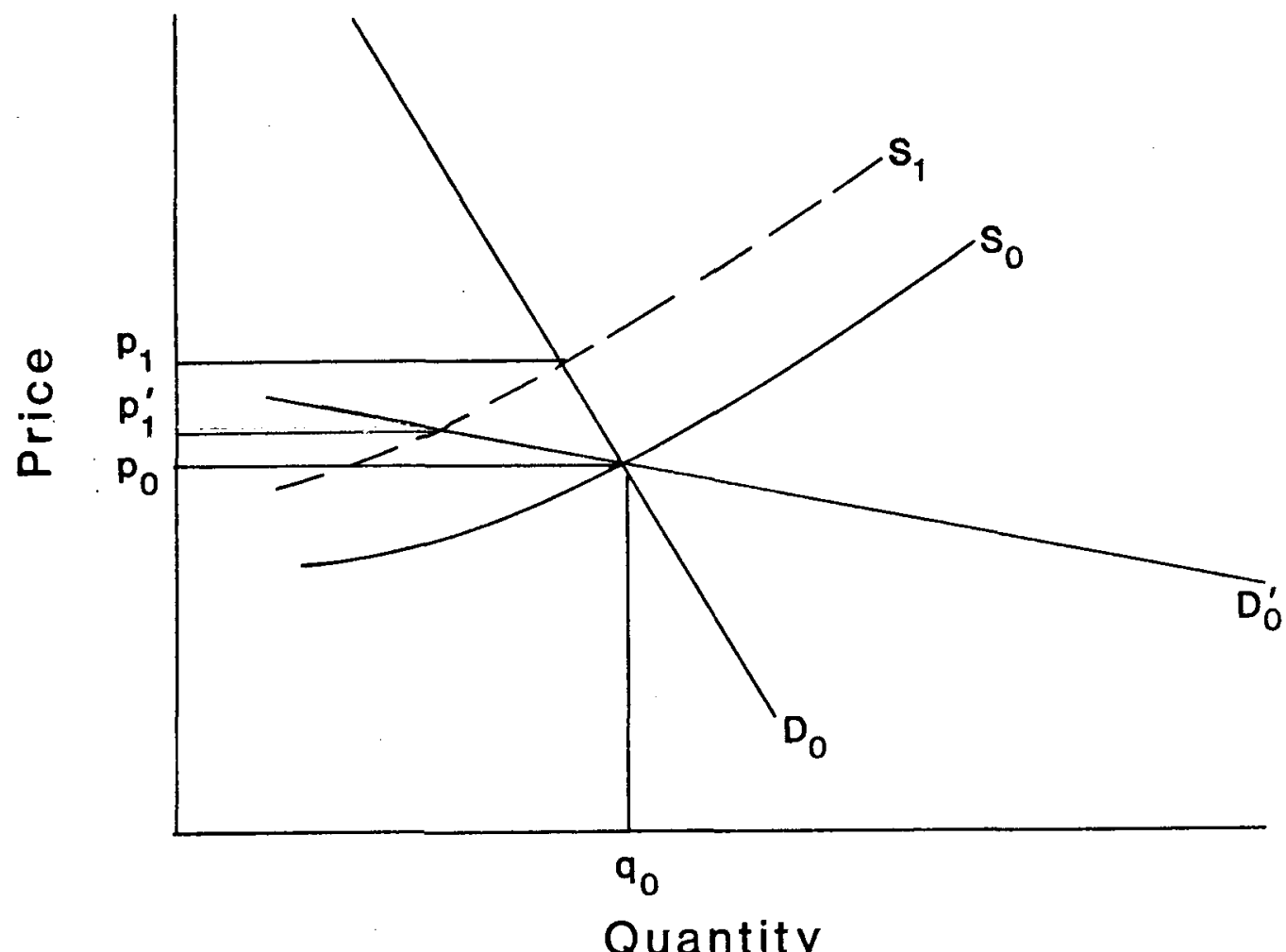

Fig. C-1. A shift in the supply function in the face of both inelastic and elastic demand.

basis for the consensus goes back to February of 1980, when OPEC'S Long-Term Strategy Committee delivered a report to the OPEC Secretariat. That report never has been released to the public, but its contents have become widely known in the industry. On the basis of assumptions about demand elasticities and supply-side management policies, the report concluded that over the long run the real price of oil would increase about as rapidly as the real growth rate of the Organization for Economic Cooperation and Development (OECD), economies, that is, $3.5 \%$ to $3.8 \%$ per year.

More recently, the World Bank has been analyzing rather carefully the trends in world oil prices. That institution monitors all principal commodity prices as part of its normal economic analysis and reporting function, but this year especial attention has been given to oil prices in preparation for a discussion of energy costs in the 1981 World Development Report. ${ }^{20}$ 
TABLE C-VI

PETROLEUM PRICES, 1960 to 1977: REALIZED PRICES

OF SAUD I ARABIAN LIGHT CRUDE

$(\$ / b \mathrm{bl})$

Petroleum Pricesa

\begin{tabular}{lcc}
$\frac{\text { Year }}{1960}$ & (Current $\$)$ & (Constant 1977\$) \\
1961 & 1.5 & 3.9 \\
1962 & 1.5 & 3.9 \\
1963 & 1.4 & 3.7 \\
1964 & 1.4 & 3.6 \\
1965 & 1.3 & 3.3 \\
1966 & 1.3 & 3.2 \\
1967 & 1.3 & 3.2 \\
1968 & 1.3 & 3.2 \\
1969 & 1.3 & 3.4 \\
1970 & 1.3 & 3.3 \\
1971 & 1.3 & 3.0 \\
1972 & 1.7 & 3.6 \\
1973 & 1.9 & 3.7 \\
1974 & 2.7 & 4.3 \\
1975 & 9.8 & 12.5 \\
1976 & 10.7 & 11.8 \\
1977 & 11.5 & 12.6 \\
& 12.4 & 12.4 \\
\hline 197 & &
\end{tabular}

aprices refer to light crude oil, 34 to 34.9 API gravity, f.o.b. Ras Tanura.

SOURCE: Ref. 18 .

Bank's recent projections of oil prices have been based on a thorough study of the probable trends in prices of substitute energy sources. The Bank's conclusion is that real crude oil prices will increase by about $3.0 \%$ per year for the next twenty years, starting from a slightly later and higher base price than the one used in the OPEC analysis.

About the same time, the US Department of Energy's Energy Information Administration (EIA) developed a set of alternate oil price forecasts in which 
TABLE C-VII

AVERAGE OPEC OFF ICIAL SALES PRICE FOR CRUDE OIL

(\$/bbl, current prices)

$\begin{array}{rrr}\text { Year } & & \text { Price } \\ 1973 & 3.39 \\ 1974 & 11.28 \\ 1975 & 11.02 \\ 1976 & 11.77 \\ 1977 & 12.88 \\ 1978 & 12.93\end{array}$

Month

January

February

March

Apr il

May

June

JuTy

August

September

October

November

December
1979

13.62

13.74

14.01

16.05

16.48

18.72

20.13

20.14

20.14

20.81

24.20

25.65
1980

28.15

28.97

29.05

29.80

30.50

30.93

31.47

31.59

32.16

31.96

32.93

$34.00^{\mathrm{a}}$

apreliminary.

SOURCE: Ref. 19.

the medium case foresees real prices increasing at an average annual rate of $3.4 \%$ through the year 2000. The EIA low case is a constant real price, and the high case is an $8.3 \%$ annual rate of increase through 2000 . The medium case is based on the assumption of tight supplies but no major disruption. The high case is based on a scenario involving two major world supply disruptions in the 1980s, each of which causes a shortfall of 1 to 2 million barrels per day for at least six months. ${ }^{21}$

However, even these projections may not give sufficient weight to the three new factors mentioned above. A more recent study by the Wharton Econometric Forecasting Associates ${ }^{12}$ projects oil prices to increase 
$1.1 \%$ per year from 1980 to 1986 . This forecast is based on the assumption that non-oil energy supplies to industrial countries will increase by $3.6 \%$ per year, whereas oil supplies will decrease by $0.4 \%$. Nuclear power outside of the US is expected to grow particularly rapidly, as shown in Table C-VIII.

The EIA's range of forecasts is too wide to be very useful for planning purposes. It may be preferable to take the Wharton forecast of $1 \%$ per year real price increases for 1980 to 1986 and extend it to 2000 as a lower bound case. Given that the longer term consensus for real price increases is around $3 \%$ per year, it may be appropriate to take $1 \%, 3 \%$, and $5 \%$ per year as three alternative real price increase projections over the period under study. The oil companies, in fact, are using long-term real price increase forecasts in the $r$ ange of $2 \%$ to $4 \%$ per year.* *John Oshinsky, American Petroleum Institute, personal communication,
July 1981.

TABLE C-VIII

OECD ENERGY SUPPLY ASSUMPTIONS

UNDERLYING THE WHARTON OIL PRICE FORECASTS

\begin{tabular}{l} 
Source \\
\hline Natural gas \\
Geo/Hydro power \\
Nuclear \\
Coal \\
Non-0i1 subtotal \\
Crude oil \\
Total energy
\end{tabular}

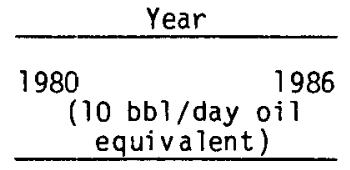

$15.5 \quad 16.9$

$5.2 \quad 6.3$

$2.8 \quad 5.0$

$\underline{15.0} \quad \underline{19.5}$

$38.5 \quad 47.7$

$34.9 \quad 34.0$

$\begin{array}{ll}73.4 & 81.7\end{array}$

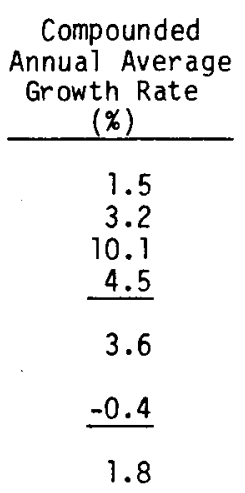

SOURCE: Ref. 19, p. 18. 


\section{APPENDIX D}

\section{ESTIMATES FOR TEMPERATURE DRAWDOWN}

As water flows through the reservoir system, heat is transferred from the rock to the water. As a result the rock gradually cools over time. The cooling process was accounted for in our model in the following way.

$$
T_{t+1}=T_{i n j}+\left(T_{\text {rock }}-T_{i n j}\right) \operatorname{erf}\left(Z_{t}\right)
$$

where:

$$
\begin{aligned}
& T_{t+1}=\text { rock temperature at beginning of year } t+1 \text { (or end of year } t \text { ) } \\
& T_{i n j}= \text { temperature of water reinjected into the reservoir (constant) } \\
& T_{\text {rock }}=\begin{aligned}
\text { rock temperature reached when drilling was completed (before any } \\
\text { cooling resulted from water flowing through reservoir) }
\end{aligned} \\
& \operatorname{erF}\left(Z_{t}\right)=\text { error function of } Z_{t}=(2 / \sqrt{\pi}) \int_{0}^{Z_{0}} e^{-x^{2}} d x \text {, where } \\
& Z_{t}=\sqrt{\frac{\lambda \rho C}{t^{\prime}}}\left(\begin{array}{l}
\pi R^{2} N F \\
n_{t} C_{w}
\end{array}\right)
\end{aligned}
$$

and where:

$\pi R^{2}=$ area of one fracture $\left(m^{2}\right)$

$\mathrm{NF}=$ number of fractures

$C_{w}=$ heat capacity of water $=4200 \mathrm{~J} / \mathrm{kg} \mathrm{K}$

$C_{r}=$ heat capacity of granite $=1000 \mathrm{~J} / \mathrm{kg} \mathrm{K}$

$m_{t}=$ water mass flow rate through the reservoir system in year $t(\mathrm{~kg} / \mathrm{sec})$

$t^{\prime}=$ time (seconds) $=t \times 31536000$

$\dot{\lambda}=$ thermal conductivity of granite $=3.0 \mathrm{~W} / \mathrm{mk}$

$\mathrm{p}=$ rock density $\approx 2500 \mathrm{~kg} / \mathrm{m}^{3}$ 
Several means of obtaining values of the function, erf $\left(z_{t}\right)$, were available for use in our model. One was to employ the Tables of the Error Function and Its Derivative, ${ }^{16}$ which gave values accurate to fifteen decima 1 places. A second method was to compute values of the function using a power series, or an asymptotic expansion for large values of $z_{t}$. The second method was used in our analysis, al though resulting values in several runs were checked against the tables to guarantee accuracy. The computational algorithms used are detailed below.

A general expansion for the function $Z(t)$ is given by the following asymptotic expansion:

$$
\begin{aligned}
1-\operatorname{erf}\left(z_{t}\right) & \approx \frac{2}{\sqrt{\pi}} \frac{e^{-z_{t}^{2}}}{2 z_{t}}\left[1-\frac{1}{\left(2 z_{t}^{2}\right)^{2}}+\frac{1 \cdot 3}{\left(2 z_{t}^{2}\right)^{2}}-\frac{1 \cdot 3 \cdot 5}{\left(2 z_{t}^{2} 1\right)^{3}}\right. \\
& \left.+\frac{1 \cdot 3 \cdot 5 \cdot 7}{\left(2 z_{t}^{2}\right) 4}-\cdots\right] .
\end{aligned}
$$

In our model, with $z_{t} \geq 2$, the following expression was used.

$$
\begin{aligned}
\operatorname{erf}\left(z_{t}\right) & =\frac{e^{-z_{t}^{2}}}{z_{t \sqrt{\pi}}}\left[1-\frac{1}{2 z_{t}^{2}}+\frac{1}{\left(2 z_{t}^{2}\right)^{2}}-\frac{1 \cdot 3 \cdot 5}{\left(2 z_{t}^{2}\right)^{3}}+\frac{1 \cdot 3 \cdot 5 \cdot 7}{\left(2 z_{t}^{2}\right)^{4}}\right. \\
& \left.-\frac{1 \cdot 3 \cdot 5 \cdot 7 \cdot 9}{\left(2 z_{t}^{2}\right)^{5}}\right]
\end{aligned}
$$

The true value of erf $\left(z_{t}\right)$ lies sonewhere between the value calculated above and the value that would result from adding one more term to the series. Therefore, the error in the above calculation must be less than

$$
\frac{e^{-z_{t}^{2}}}{z_{t} \sqrt{\pi}}\left(\frac{1 \cdot 3 \cdot 5 \cdot 7 \cdot 9 \cdot 11}{\left(2 z^{2}\right)_{t}^{6}}\right) \text {. }
$$


If $z_{t}=2$, the error is less than $2 \times 10^{-4}$. For values of $z_{t}$ equal to 3 and 4 , the error is less than $6.9 \times 10^{-9}$ and $1.5 \times 10^{-13^{t}}$, respectively. This means that all computations of erf $\left(z_{t}\right)$ for values of $Z \geq 2$ were accurate to at least 3 decimal points, which was appropriate for our analysis. series:

For $z_{t}<2$, the calculations of erf $\left(Z_{t}\right)$ were made from the power

$$
\operatorname{erf}\left(z_{t}\right)=\frac{2}{\sqrt{\pi}}\left(z-\frac{z^{3}}{1 ! 3}+\frac{z^{5}}{2 ! 5}-\frac{z^{7}}{3 ! 7}+\frac{z^{9}}{4 ! 9}-\cdots\right)
$$

This series was carried as far as necessary for each $z_{t}$ in the model to also guarantee accuracy to three decimal places. 
1. R. G. Cummings and G. E. Morris, "Economic Modeling of Electricity Production from Hot Dry Rock Geothermal Reservoirs: Methodology and Analysis," Electric Power Research Institute, Palo Alto, California, EPRI EA-630 (September 1979).

2. R. G. Cummings and G. E. Morr is, "Economic Factors Relevant for Electric Power Produced from Hot, Dry Rock Geothermal Resources," case studies for Fenton Hill, New Mexico, and Imperial Valley, California, reports for Department of Energy contract DOE DE-AS04-79ET-27017 (December 1979).

3. "Geothermal Resource and Implementation Assessment at Wallops Flight Center," Weston Designers and Consultants report for NASA contract NASA-3297 (January 1981).

4. C. J. Arundale, "User's Manual for HDR3 Computer Code," Los Alamos National Laboratory report (in preparation).

5. Geocost: A Computer Program for Geothermal Cost Analysis," Batelle Pacif ic Northwest Laborator ies report BNWL-1888 (February 1975).

6. "Industrial Assessment of Drilling Completion and Workover Costs of the Well and Fracture Subsystems of HDR Geothermal Systems," Republic Geothermal, Inc., Santa Fe Springs, California (March 1979).

7. "Petroleum Price Summary," Monthly Energy Review, DOE-EIA-0035(81/05), May 1981.

8. "Joint Association Survey of Drilling Costs," American Petroleum Institute, 2101 L St., NW, Washington, DC 20037, 1960 through 1979.

9. Statistical Abstract of the United States (US Government Printing Office, Washington, 1980), Table 796.

10. World Development Report (International Bank for Reconstruction and Development, Washington, DC, 1981).

11. Annual Report to Congress, US Department of Energy, Energy Information Administration (US Government Printing Office, Washington, DC, 1981).

12. V. Zanoyan, "Outlook for International Crude 0il Markets: Summary Tables," prepared for the biannual DIEMEX meeting, Wharton Econometric Forecasting Associates, Philadelphia (July 1981).

13. "Options for the Discount Interest Rate," US Water Resources Council, 2120 L St., NW, Washington, DC 20037 (November 1975).

14. 0. Herfendah1, and A. V. Kneese, Economic Theory of Natural Resources (Merrill Publishing Company, Columbus, 1974). 
15. B. M. Fraumeni and D. W. Jorgensen, "Rates of Return by Industrial Sector in the United States, 1948-1976," Amer. Econ. Rev. 70, 2, pp. 326-330 (May 1980).

16. Tables of the Error Function and Its Derivative, National Bureau of Standards, US Department of Commerce, Applied Mathematics Series 41 (US Government. Printing Office, Washington, DC, 1954).

17. Petroleum Engineering International, March 1981, pp. 21, 32.

18. "Price Prospects for Major Primary Commodities," World Bank report No. 814/78, Washington, DC (June 1978).

19. World 011 , February 15, 1981, p. 120.

20. "Wor 1d Development Report, 1981," Wor 1d Bank, Washington, DC, 1981. 